\title{
Transcription Regulation of the Human Telomerase Reverse Transcriptase (hTERT) Gene
}

\author{
Muhammad Khairul Ramlee ${ }^{1,+}$, Jing Wang ${ }^{1,+}$, Wei Xun Toh ${ }^{1,+}$ and Shang Li ${ }^{1,2, *}$ \\ 1 Cancer and Stem Cell Biology Program, Duke-NUS Graduate Medical School, Singapore 169857, Singapore; \\ khairul@u.duke.nus.edu (M.K.R.); wang.jing@u.duke.nus.edu (J.W.); wei.xun@u.duke.nus.edu (W.X.T.) \\ 2 Department of Physiology, Yong Loo Lin School of Medicine, National University of Singapore, \\ Singapore 117597, Singapore \\ * Correspondence: shang.li@duke-nus.edu.sg; Tel.: +65-6221-2402 \\ + These authors contributed equally to this work.
}

Academic Editor: Gabriele Saretzki

Received: 15 June 2016; Accepted: 1 August 2016; Published: 18 August 2016

\begin{abstract}
Embryonic stem cells and induced pluripotent stem cells have the ability to maintain their telomere length via expression of an enzymatic complex called telomerase. Similarly, more than $85 \%-90 \%$ of cancer cells are found to upregulate the expression of telomerase, conferring them with the potential to proliferate indefinitely. Telomerase Reverse Transcriptase (TERT), the catalytic subunit of telomerase holoenzyme, is the rate-limiting factor in reconstituting telomerase activity in vivo. To date, the expression and function of the human Telomerase Reverse Transcriptase (hTERT) gene are known to be regulated at various molecular levels (including genetic, mRNA, protein and subcellular localization) by a number of diverse factors. Among these means of regulation, transcription modulation is the most important, as evident in its tight regulation in cancer cell survival as well as pluripotent stem cell maintenance and differentiation. Here, we discuss how $h T E R T$ gene transcription is regulated, mainly focusing on the contribution of trans-acting factors such as transcription factors and epigenetic modifiers, as well as genetic alterations in hTERT proximal promoter.
\end{abstract}

Keywords: telomerase; telomere; transcription regulation; promoter; mutation

\section{Introduction}

The ends of human chromosomes are capped by telomeres which protect the chromosome termini from degradation, end-to-end fusion and recombination [1,2]. Telomeres are long stretches of 5'-TTAGGG-3' DNA repeats which end in single-stranded 3' G-rich overhangs [3,4]. The telomeric DNA repeats are bound by shelterin protein complexes consisting of Telomeric Repeat Factor I and II (TRF1, TRF2), Repressor/ Activator Protein I (RAP1), TRF1-Interacting Nuclear Protein 2 (TIN2), Tripeptidyl Peptidase I (TPP1) and Protection of Telomeres I (POT1) that distinguish naturally occurring chromosomal ends from DNA double-strand breaks [2]. Telomeric DNA repeats are synthesized by telomerase, a reverse transcriptase. Human core telomerase consists of at least two essential subunits, the protein subunit, human Telomerase Reverse Transcriptase (hTERT), and the RNA subunit, human Telomerase RNA (hTR) [5,6]. Telomerase activity is generally limited by the expression of hTERT, and is barely detected in most human adult somatic tissues, except in germ cells and some stem cells [5-9]. In cells lacking telomerase activity, about 50-200 bp of telomeric DNA repeats are lost during each cell division due to incomplete replication by DNA polymerase, and end processing $[4,10]$. 
Adult human somatic cells have limited telomere lengths ranging from 7 to $12 \mathrm{~kb}$ [11]. Therefore, progressive telomere shortening may function as an internal clock that determines the replicative capacity of normal human somatic cells [12]. When telomeres shorten to a critical limit, they become uncapped and trigger Ataxia Telangiectasia Mutated (ATM)- and/or Ataxia Telangiectasia and Rad3-Related Protein (ATR)-dependent DNA damage signaling cascades [13-15]. Through the downstream transducer kinases, Checkpoint kinase I and II (CHK1 and CHK2), the uncapped chromosomal ends are marked by distinct telomere dysfunction-induced foci (TIFs) [13]. As few as five dysfunctional telomeres are sufficient to trigger irreversible cell cycle arrest, termed replicative senescence, in primary human fibroblast cells [14-16]. As a result, normal somatic cells can only proliferate for a limited number of passages that is pre-set by their telomere length [16]. In contrast to pluripotent stem cells whose telomere length is sustained, telomerase activity in tissue-specific progenitor/stem cells is not sufficient for complete telomere maintenance [17]. Consequently, telomere length in these tissue-specific progenitor/stem cells also progressively shortens. This decrease in length limits the proliferative capacity of tissue-specific progenitor/stem cells, and contributes to normal human aging [18]. Therefore, the process of resetting telomere length during early embryogenesis is necessary to ensure sufficient telomere reserves for cell integrity during human development and aging [19].

Defects in genes that regulate telomere length homeostasis may lead to various diseases, collectively termed telomeropathies [20,21]. Patients display diverse symptoms such as premature aging and increased risk of cancer, highlighting the importance of telomere homeostasis in human health. Mutations in telomerase and telomere maintenance genes have been found in patients with telomeropathies [20-22], which results in decreased telomerase activity and accelerated telomere shortening. These genes control telomerase ribonucleoprotein maturation, assembly, recruitment, and engagement, revealing their importance in telomere length homeostasis. To add, telomerase knockout mouse models show remarkable similarity to the human disease phenotypes [23-25]. Strategies that promote the expression of $h T E R T$ and restore telomere length homeostasis could potentially delay the clinical onset of these diseases as well as normal aging in humans.

On the other hand, telomerase activity is highly elevated in $85 \%-90 \%$ of human cancers and over $70 \%$ of immortalized human cell lines $[7,26]$. This is consistent with telomerase conferring a strong selective advantage for continued growth of malignant cells [27]. These observations suggest that telomere maintenance is essential for cancer cell immortalization and that it may be possible to inhibit cancer growth by interfering with telomerase activity.

Expression and function of $h T E R T$ gene are known to be regulated at various molecular levels. However, the transcription of $h T E R T$ has been suggested to be the dominant step in the regulation of telomerase activity $[7,26]$. Previous studies on $h T E R T$ promoter have defined a core region encompassing $330 \mathrm{bp}$ upstream of the translation start site to $228 \mathrm{bp}$ downstream, extending right into the second exon of the gene [28-30]. A number of transcription factor binding sites have been identified in this core promoter. However, the molecular mechanism underlying $h T E R T$ gene activation during induced Pluripotent Stem (iPS) cell reprogramming $[31,32]$ and $h T E R T$ gene silencing during cellular differentiation remains largely unclear. On the other hand, recent studies have revealed the potential role of promoter mutations and chromosomal rearrangements in the activation of telomerase in cancer cells. These results have provided potential new strategies in targeting telomerase for cancer therapy. Here, we summarize the recent advances in the understanding of the transcriptional regulation of $h T E R T$ gene, focusing our attention on trans-acting factors, namely transcription factors and epigenetic modifiers, as well as genetic alterations in $h T E R T$ proximal region. 


\section{Trans-Acting Regulators of $h T E R T$ Transcription}

The core promoter of the $h T E R T$ gene contains several known regulatory elements including GC-motifs and E-boxes. Several other articles have elegantly reviewed the roles specific factors or protein families play in the modulation of $h T E R T$ gene expression. Here, we have chosen to focus only on factors which have been reported to bind directly to the $h T E R T$ promoter region via in vitro or in vivo DNA-protein interaction assays, such as chromatin immunoprecipitation (ChIP) and electrophoretic mobility shift assay (EMSA) (refer to Table 1 for the complete list of factors). We selected a number of well-studied factors in each category and briefly discuss its role in the regulation of the $h T E R T$ gene, specifically highlighting the complexity of the regulatory network involved in controlling the expression of $h T E R T$. As expected of a critical gene, $h T E R T$ transcription is modulated in a context-dependent manner via a multi-tiered regulatory network involving, among other means, feedback loops, and genetic and epigenetic controls. We also highlight the complexity of the $h T E R T$ proximal promoter with regards to the numerous response elements enclosed in this region (refer to Figure 1 for a schematic of the binding sites of selected transcription factors found in this region).

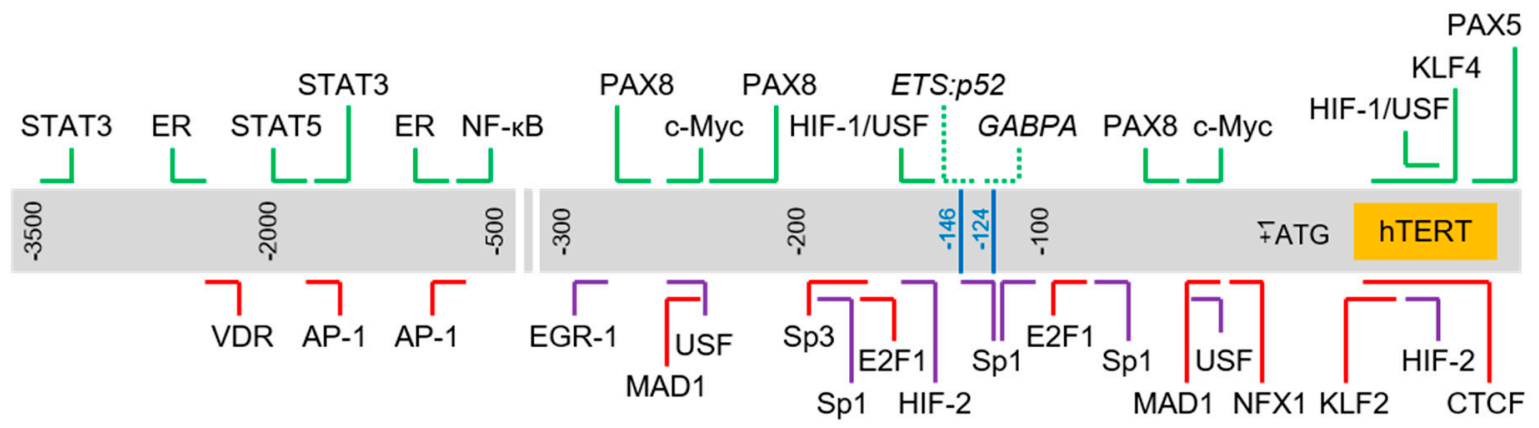

Figure 1. Schematic of transcription factor binding sites in human Telomerase Reverse Transcriptase ( $h T E R T$ ) promoter. Chromosomal sequence extending from $3.5 \mathrm{~kb}$ upstream and $150 \mathrm{bp}$ downstream of $h T E R T$ translation start site $(+1)$ is represented by the gray box. Horizontal lines above and below the box indicate approximate binding sites of respective transcription factors. Blue lines: hotspot promoter mutations ("-124" corresponds to C228T mutation; "-146" corresponds to C250T mutation); green: activator; red: repressor; purple: regulator with dual roles; dotted line: regulator bound to sites created by hotspot mutations. 
Table 1. List of factors reported to bind to human Telomerase Reverse Transcriptase ( $h T E R T)$ promoter and regulate its expression.

\begin{tabular}{|c|c|c|c|c|c|c|c|c|}
\hline Regulator & Activator/Repressor & Cell Tested & Binding Site & Binding Assay & Reference & Co-Regulator & Positive Regulators & Negative Regulators \\
\hline $\begin{array}{l}\text { Androgen } \\
\text { receptor }\end{array}$ & Repressor & LNCaP, PC3 & ND & ChIP & [33] & & & \\
\hline \multirow{2}{*}{ AP-1 } & Repressor & HeLa & $-1655 ;-718$ & EMSA, ChIP & [34] & & WT1 [35] & \\
\hline & Activator & HeLa & $-378 /+1$ & ChIP & [36] & HBZ/Sp1 [36] & & \\
\hline $\mathrm{AP}-2 \beta$ & Activator & $\begin{array}{l}\text { H1299, H322, } \\
\text { HBE, WI-38 }\end{array}$ & $-43 /-18$ & EMSA, ChIP & [37] & & & BBR [38]; WT1 [35] \\
\hline ARID1A & Repressor & OVISE & ND & ChIP & [39] & SIN3A [39] & & \\
\hline$\beta$-catenin & Activator & $\begin{array}{c}\text { NTera2, SW480, } \\
\text { 293T, HCT116, } \\
\text { MCF7 }\end{array}$ & $\begin{array}{l}-255 /+40 \\
-659 /-653\end{array}$ & EMSA, ChIP & {$[40,41]$} & Klf4 [40] & & TCF1 [40] \\
\hline Cbfa1 & Repressor & BMSSC & $\begin{array}{l}-888 /-865 ; \\
-2815 /-2792 \\
\end{array}$ & EMSA, ChIP & {$[42]$} & & & \\
\hline c-Myc & Activator & U937, HL60, A549 & $\begin{array}{c}-242 /-237 \\
-34 /-29\end{array}$ & EMSA, ChIP & [43-45] & $\begin{array}{c}\text { Sp1 [46];E6 [47]; } \\
\text { NFX1-123 [48]; } \\
\text { p300 [49];E7 [50]; } \\
\text { Max [51]; Ets2 [52] }\end{array}$ & $\begin{array}{c}\text { E6 [53-55]; Max [44]; BRCA1/Nmi } \\
\text { [56]; NF-kB [57,58]; FOXO3a [59]; } \\
\text { MMP-9 [60]; Tax [58]; estrogen } \\
\text { [51]; Aurora-A [61]; LMP1 [62]; } \\
\text { survivin [63]; PKC [64]; SMYD3 } \\
\text { [65]; STAGA complex [66]; EGF } \\
\text { [67]; CSF1R [68]; GSK3 [69]; DJ-1 } \\
\text { [70]; leptin [71]; BDNF [72]; SIRT1 } \\
\text { [73]; saquinavir [74]; bile acids [75]; } \\
\text { IRF-4 [76] }\end{array}$ & $\begin{array}{c}\text { HIF-1 } \alpha \text { [77-80]; BRCA1 [81,82]; } \\
\text { cordyceptin [83]; 15d-PGJ2 [84,85]; } \\
\text { rosiglitazone [85]; Mad [57,86,87]; } \\
\text { ceramide [45]; p53 [88]; Tax [89]; } \\
\text { 5-aza-CR [90]; DAC [91]; TMPyP4 } \\
\text { [92]; p27KIP1 [93]; genistein [94]; } \\
\text { reFIP-gts [95]; 4-hydroxynonena } \\
\text { [96]; gambogic acid [97]; butein } \\
\text { [98]; wogonin [99]; WT1 [35]; E2F1 } \\
\text { [100]; ATO [101]; DADS [102] }\end{array}$ \\
\hline COUP-TFII & Repressor & HeLa & $-201 /+35$ & EMSA & [103] & & & \\
\hline CPSF4 & Activator & $\begin{array}{c}\text { H1299, A549, } \\
\text { H322, WI-38, HBE }\end{array}$ & $-378 /+60$ & ChIP & [104] & & & \\
\hline CTCF & Repressor & HeLa, SW480, BJ & $+16 /+126$ & EMSA, ChIP & [105] & & ROS [106]; TGF- $\beta$ [107] & Sulforaphane [108] \\
\hline DEK & Repressor & $\mathrm{HeLa}$ & ND & ChIP & [109] & & Tax [109] & \\
\hline E2F1 & Repressor & SCC25 & $\begin{array}{l}-174 /-170 \\
-98 /-94\end{array}$ & EMSA & [110] & & $\begin{array}{l}\text { TGF } \beta / \text { Smad3 [111]; } \\
\text { PPAR } \alpha / p 16 \text { [112] }\end{array}$ & \\
\hline E6 & Activator & HK & ND & ChIP & [113] & c-Myc [113] & & \\
\hline \multirow{2}{*}{ EGR-1 } & Activator & JAR, JEG-3 & $-281 /-273$ & EMSA & [114] & & & \\
\hline & Repressor & CaSki, SiHa & $-281 /-273$ & EMSA & [115] & & & \\
\hline eNOS & Activator & HUVEC & $-949 /-935$ & ChIP & [116] & $\mathrm{ER} \alpha[116]$ & & \\
\hline ER81 & Activator & $293 \mathrm{~T}$ & $\begin{array}{l}+288 /+291 \\
+390 /+393\end{array}$ & EMSA & [117] & & $\begin{array}{c}\text { HER2/Neu, ERK/MAPK, } \\
\text { Ras/Raf [117] }\end{array}$ & \\
\hline
\end{tabular}


Table 1. Cont

\begin{tabular}{|c|c|c|c|c|c|c|c|c|}
\hline Regulator & Activator/Repressor & Cell Tested & Binding Site & Binding Assay & Reference & Co-Regulator & Positive Regulators & Negative Regulators \\
\hline $\begin{array}{l}\text { Estrogen } \\
\text { receptor }\end{array}$ & Activator & $\begin{array}{c}\text { MCF7, SiHa, } \\
\text { NHK, } \\
\text { MDA-MB231, } \\
\text { HeLa, OVCA-433, } \\
\text { HUVEC }\end{array}$ & $\begin{array}{c}-2677 \\
-949 /-935\end{array}$ & EMSA, ChIP & $\begin{array}{c}{[51,116,} \\
118]\end{array}$ & eNOS [116] & Sp1 [118]; MAPK [119]; leptin [120] & $\begin{array}{c}\text { I3C [121]; 15d-PGJ2 [84]; } \\
\text { progesterone [122]; miR-498 [120] }\end{array}$ \\
\hline \multirow[t]{2}{*}{ ETS } & Activator & $\begin{array}{c}\text { A549, H1299, } \\
\text { MCF7, NIH3T3, } \\
\text { A-431, MCF7, } \\
\text { ME180 }\end{array}$ & $\begin{array}{l}-246 /-243 \\
-99 /-96 \\
-23 /-13\end{array}$ & EMSA, ChIP & $\begin{array}{l}{[52,123-} \\
125]\end{array}$ & $\begin{array}{l}\text { c-Myc [52]; } \\
\text { EWS [126] }\end{array}$ & EGF/MAPK $[123,124]$ & $\operatorname{PPAR} \gamma[127]$ \\
\hline & Repressor & U937, K562 & -351 & EMSA & [125] & & WT1 [35] & \\
\hline GLI1/2 & Activator & HT29, 293T & $-1226 /+438$ & ChIP & {$[128]$} & & & \\
\hline GRHL2 & Activator & $\begin{array}{l}\text { SCC4, NHOK, } \\
\text { SCC15 }\end{array}$ & $-21 /-19$ & ChIP, PMP & {$[129,130]$} & & & \\
\hline HIF-1 & Activator & $\begin{array}{l}\text { ME180, JEG-3, } \\
\text { JAR }\end{array}$ & $\begin{array}{l}-165 /-158 \\
+44 /+51\end{array}$ & EMSA, ChIP & {$[131,132]$} & & LPA [133]; PI3K [133] & \\
\hline \multirow{2}{*}{ HIF-2 } & Activator & A498 & $\begin{array}{l}-165 /-158 \\
+44 /+51\end{array}$ & ChIP & [134] & & & \\
\hline & Repressor & $\mathrm{U} 251$ & $\begin{array}{l}-165 /-158 \\
+44 /+51\end{array}$ & ChIP & [134] & & & \\
\hline hnRNP D & Activator & $\begin{array}{l}\text { NHOK, SCC15, } \\
\text { SCC } 4\end{array}$ & $-188 /-42$ & ChIP, PMP & [130] & & & \\
\hline hnRNP K & Activator & $\begin{array}{l}\text { NHOK, SCC15, } \\
\text { SCC } 4\end{array}$ & $-188 /-42$ & & [130] & & & \\
\hline Hsp90 & Activator & SCC4 & $\begin{array}{l}-465 /-341 \\
-188 /+5\end{array}$ & ChIP & [135] & & & \\
\hline KLF2 & Repressor & $\begin{array}{l}\text { Kit 225, primary } \\
\text { human T cells }\end{array}$ & $+9 /+30$ & EMSA, ChIP & [136] & & & \\
\hline KLF4 & Activator & $\mathrm{FaDu}$ & $+18 /+77$ & EMSA, ChIP & [137] & & & \\
\hline LSD1 & Repressor & HL60 & ND & ChIP & [138] & & & \\
\hline MAD1 & Repressor & WI38, 293T, U937 & $\begin{array}{l}-243 /-238 \\
-34 /-29\end{array}$ & EMSA, ChIP & {$[86,139]$} & $\operatorname{Max}[140]$ & $\begin{array}{l}\text { Sulforaphane [108]; PPAR } \gamma \\
\text { ligands [85]; DADS [102] }\end{array}$ & $\begin{array}{l}\text { miR-202 [140]; MMP-9 [60]; } \\
\text { c-Myc [57,86]; miR-202 [140] }\end{array}$ \\
\hline Maz & Repressor & HFK & $\mathrm{ND}$ & ChIP & [141] & & HBx [142] & E6 [141] \\
\hline МСРH1 & Repressor & $\mathrm{HeLa}$ & $+4 /+68$ & EMSA & [143] & & & \\
\hline Menin & Repressor & $\begin{array}{c}\text { MCF-7, C33A, } \\
\text { HeLa }\end{array}$ & Sequence-indep & ndentEMSA & [144] & JunD [145] & & HBZ [145] \\
\hline
\end{tabular}


Table 1. Cont.

\begin{tabular}{|c|c|c|c|c|c|c|c|c|}
\hline Regulator & Activator/Repressor & Cell Tested & Binding Site & Binding Assay & Reference & Co-Regulator & Positive Regulators & Negative Regulators \\
\hline MSH2 & Activator & $\begin{array}{c}\text { NHOK, SCC15, } \\
\text { SCC4 }\end{array}$ & $-377 /-207$ & ChIP, PMP & [130] & & & \\
\hline MZF-2 & Repressor & $\begin{array}{l}\text { C33A, SiHa, HeLa, } \\
\text { ME100, K562 }\end{array}$ & $-687 /-680$ & EMSA & [146] & & & \\
\hline NF-kB & Activator & $\begin{array}{l}\text { U937, SH-SY5Y, } \\
\text { SK-N-MC }\end{array}$ & $-650 /-638$ & ChIP, EMSA & {$[147,148]$} & & $\begin{array}{c}\text { STAT3 [149]; Tax [58,150]; } \\
\text { PI3K/Akt [151] }\end{array}$ & $\begin{array}{c}\text { ATO [101]; IkB } \alpha \text { [152]; } \\
\text { curcumin [148]; pelitinib [153] }\end{array}$ \\
\hline NFAT1 & Activator & MCF7 & $\begin{array}{c}-775 /-771 ; \\
-40 /-36\end{array}$ & ChIP & [154] & & Sp1 [154] & \\
\hline \multirow[t]{2}{*}{ NFX1 } & Repressor & HFK & $-28 /-19$ & EMSA & {$[48]$} & $\begin{array}{c}\text { Sin3A/HDAC } \\
\text { [155] }\end{array}$ & & E6/E6-AP [48] \\
\hline & Activator & HFK & $-28 /-19$ & EMSA & {$[48]$} & c-Myc [48] & E6 [55] & WT1 [35] \\
\hline PAX5 & Activator & Raji, Nalm6 & $\begin{array}{l}+110 /+137 \\
+489 /+516\end{array}$ & EMSA: ChIP & [156] & & & \\
\hline PAX8 & Activator & $\begin{array}{l}\text { LN18, SF268, } \\
\text { U87MG }\end{array}$ & $\begin{array}{c}-272 /-268 ; \\
-236 /-219 ; \\
-217 /-202 ; \\
-57 /-41\end{array}$ & EMSA & [157] & & & \\
\hline PITX1 & Repressor & A2058 & $\begin{array}{l}-1366 /-1361 ; \\
-1347 /-1342 ; \\
-1325 /-1320 \\
\end{array}$ & EMSA, ChIP & [158] & & & miR-19b [159] \\
\hline PreS2 & Activator & HepG2.2.15 & $-407 /-387$ & EMSA & [160] & & & \\
\hline Reptin & Activator & AGS, HGC-27 & $\mathrm{ND}$ & ChIP & [161] & c-Мyc [161] & & \\
\hline RFPL3 & Activator & $\begin{array}{l}\text { H1299, A549, } \\
\text { WI-38, HBE, }\end{array}$ & ND & ChIP & [162] & CBP [163] & & \\
\hline SNAI1 & Repressor & HaCaT, HEK293 & $\begin{array}{l}-242 /-237 \\
-34 /-29\end{array}$ & ChIP & [80] & & TGF $\beta[80]$ & \\
\hline \multirow[t]{2}{*}{ Sp1 } & Activator & $\begin{array}{l}\text { C33A, ME180, } \\
\text { SiHa, HeLa }\end{array}$ & $\begin{array}{c}-182 ;-160 \\
-128 ;-108 ;-79\end{array}$ & EMSA & {$[30,46]$} & $\begin{array}{l}\text { CBP [164]; } \\
\text { c-Myc [46] }\end{array}$ & $\begin{array}{c}\text { E6 [53,141]; HBZ/JunD [36]; } \\
\text { LANA [165,166]; Tax/NF-kB [58]; } \\
\text { genistein [167]; survivin [63]; } \\
\text { BDNF [72]; PKC /NF-kB [64]; } \\
\text { SMYD3 [65]; IRF-4 [76]; } \\
\text { MCAF1 [168]; NFAT [154]; } \\
\text { HBx [169]; HMGA2 [170] }\end{array}$ & $\begin{array}{l}\text { p53 [171]; p73 [172,173]; } \\
\text { cordyceptin [83]; 15d-PGJ2 [84]; } \\
\text { p27KIP1 [93]; arsenic/ROS [25]; } \\
\text { ceramide ([174]; ATO [101]; } \\
\text { DADS [102]; E2 [175]; E2F-1 [176]; } \\
\text { p16 [177]; butylidenephthalide } \\
\text { [178]; indole-3-carbinol [121]; } \\
\text { nilotinib/dasatinib [179]; } \\
\text { CDDO-Me [180]; homocysteine } \\
\text { [181]; triptolide [182] }\end{array}$ \\
\hline & Repressor & $\begin{array}{l}\text { IMR90, WI38, } \\
\text { HFF }\end{array}$ & $\begin{array}{c}-182 ;-160 ; \\
-128 ;-108 ;-79\end{array}$ & EMSA, ChIP & [183] & $\begin{array}{l}\text { HDAC [183]; } \\
\text { CtBP [184] }\end{array}$ & TAK1 [185] & E1A [184] \\
\hline
\end{tabular}


Table 1. Cont

\begin{tabular}{|c|c|c|c|c|c|c|c|c|}
\hline Regulator & Activator/Repressor & Cell Tested & Binding Site & Binding Assay & Reference & Co-Regulator & Positive Regulators & Negative Regulators \\
\hline Sp3 & Repressor & $\begin{array}{l}\text { A549, IMR90, } \\
\text { WI38, HFF }\end{array}$ & $-195 /-168$ & EMSA, ChIP & $\begin{array}{c}{[174,183,} \\
186]\end{array}$ & & Ceramide [174] & \\
\hline SPT5 & Activator & $\begin{array}{c}\text { SW620, HT29, } \\
\text { Colo320, RKO, } \\
\text { HCE } 8693\end{array}$ & $-378 /+60$ & ChIP & [187] & & & \\
\hline STAT3 & Activator & $\begin{array}{c}\text { HepG2, MCF-7, } \\
\text { DU-145, K562, } \\
\text { A172, HS27 }\end{array}$ & $\begin{array}{l}-3308 /-3300 ; \\
-1587 /-1579\end{array}$ & ChIP & $\begin{array}{c}{[71,167} \\
188-190]\end{array}$ & & $\begin{array}{l}\text { miR-21 [191]; leptin [71,188]; } \\
\text { GSK3 [69]; HCVc [192] }\end{array}$ & \\
\hline STAT5 & Activator & $\begin{array}{c}\text { ILT-Hod, } \\
\text { K562-ADM, K562 }\end{array}$ & $-1872 /-1864$ & ChIP & $\begin{array}{c}\text { [189,193, } \\
194]\end{array}$ & & IL-2/JAK [193]; EPO [195,196] & \\
\hline TAL1 & Repressor & HeLa & ND & ChIP & [197] & $\operatorname{Tax}[197]$ & & HBZ/JunD [197] \\
\hline TEIF & Activator & $\begin{array}{l}\text { HeLa, 293, } \\
\text { HT1080, 293T }\end{array}$ & $-120 /+90$ & EMSA & {$[198,199]$} & & & MSP58 [199] \\
\hline \multirow[t]{2}{*}{ USF } & Activator & $\begin{array}{c}\text { SKBR3, } \\
\text { MDA-MB-231, } \\
\text { MCF7, OVCAR3, } \\
\text { 293T, SKOV3, } \\
\text { Wi38, HFF, BJ, } \\
\text { lymphocytes, } \\
\text { HEK293 }\end{array}$ & $\begin{array}{c}-242 /-237 \\
-165 /-160 \\
-34 /-29 \\
+44 /+49\end{array}$ & EMSA & {$[200,201]$} & & p300, p38/MAPK [200]; IRF-4 [76] & Truncated USF2 [201]; ATO [101] \\
\hline & Repressor & OEC-M1, HFK & $\begin{array}{l}-242 /-237 \\
-34 /-29\end{array}$ & EMSA, ChIP & {$[54,202]$} & & & \\
\hline VDR & Repressor & PC3, LNCaP & $-2530 /-2516$ & EMSA & [203] & RXR [203] & & \\
\hline WT1 & Repressor & $293 \mathrm{~T}$ & $-423 /-307$ & EMSA & [204] & & PI3K pathway [150] & \\
\hline
\end{tabular}




\subsection{Transcription Activators of hTERT}

\subsection{1. c-Myc}

c-Myc, together with its dimerization partner Max, binds to regulatory elements called E-boxes and recruits histone acetyltransferases (HATs) to exact an activating effect on the transcription of various genes. Human TERT gene is one of them; c-Myc binds to two E-box sequences found on the core promoter of $h T E R T$, leading to the upregulation of the expression of the gene and telomerase activity [43-45]. Mutating these sites weakens the promoter activity of $h T E R T$ gene $[45,46]$. In addition, overexpression of c-Myc in squamous cell carcinoma cells and human foreskin keratinocyte cells resulted in the upregulation of the $h T E R T$ promoter activity [46]. The transcription activating role of c-Myc on $h T E R T$ gene is mediated by the recruitment of the histone acetyltransferase (HAT) complex called SPT3-TAF9-GCN5 acetyltransferase complex (STAGA) and the transcription co-activator Mediator complex [66].

On the other hand, c-Myc alone may not be sufficient to drive the activation of $h T E R T$ expression. E6-transduced human foreskin keratinocytes (HFKs) did not show an increase in c-Myc expression, even though the cells attained replicative immortality [205]. This suggests that additional factors may be required in order to upregulate $h T E R T$ expression in these cells. Indeed, c-Myc was found to act cooperatively with Specificity Protein 1 (Sp1) in the activation of $h T E R T$ transcription via combinatorial binding of these two factors on their respective cis elements in the hTERT promoter [53]. When the E-boxes and GC-rich motifs (response elements of Sp1) were mutated, E6-mediated activation of telomerase expression was abolished. This also explains the observation that c-Myc and Sp1 expression correlates with $h T E R T$ transcription in various cancer cell lines.

Besides Sp1, numerous other factors play a role in modulating c-Myc-mediated regulation of $h T E R T$ transcription. Estrogen has been shown to activate c-Myc expression in breast cancer cell line, MCF-7 [51]. This, on top of direct activation of $h T E R T$ by estrogen receptor (ER) (see below), enhances $h T E R T$ transcription and telomerase activity in these cells. Aurora-A activates c-Myc expression and thence $h T E R T$ promoter activity in ovarian and breast epithelial cancer cells [61]. Nuclear Transcription Factor, X Box-Binding Protein 1 variant 123 (NFX1-123) and c-Myc, together with an unknown factor which acts upstream of the hTERT core promoter, co-activate $h T E R T$ gene expression in human foreskin keratinocytes [48]. Survivin induces the phosphorylation of c-Myc (and Sp1) and enhances its transactivation of $h T E R T$ transcription [63]. p300 interacts with and stabilises c-Myc via the latter's Topologically Associated Domain (TAD) and they both co-activate $h T E R T$ gene expression [49]. Protein Kinase $\mathrm{C} \theta$ (PKC $\theta$ ) activates Nuclear Factor $\kappa B$ (NF- $\mathrm{kB}$ ) signalling which in turn enhances c-Myc binding to $h T E R T$ promoter in activated human T lymphocytes [64]. ETS Proto-Oncogene 2 (Ets2) interacts with c-Myc and together they bind to $h T E R T$ promoter sequence and mediate breast cancer proliferation [52]. Colony Stimulating Factor 1 Receptor (CSF1R), upon induction by its ligand Colony Stimulating Factor 1 (CSF1), gets internalised into activated immortalized epithelial cells which lead to elevated binding of c-Myc to $h T E R T$ promoter [68]. Protein deglycase DJ-1 regulates c-Myc expression and thus $h T E R T$ promoter activity in renal and ovarian carcinoma cells [70]. Leptin upregulates binding of c-Myc (and Signal Transducer and Activator of Transcription 3 (STAT3)) to $h T E R T$ promoter and induces $h T E R T$ expression in HepG2 cells [71]. Brain-Derived Neurotrophic Factor (BDNF) activates $h T E R T$ expression and telomerase activity in spinal cord motor neurons via Mitogen-Activated Protein Kinase (MAPK)/Phosphatidylinositol-4,5-Bisphosphate 3-Kinase (PI3K) pathway which induces, among others, c-Myc expression [72]. Matrix Metallopeptidase 9 (MMP-9) facilitates in the switch from repressive Mad/Max-bound state to activating c-Myc/Max-bound state of the $h T E R T$ promoter in glioma cells [60]. Sirtuin 1 (SIRT1) upregulates c-Myc expression through activation of Forkhead Box O3A (FOXO3a) in human umbilical cord fibroblast (HUC-F2) cells and this leads to increased hTERT expression and longer lifespan of the cells [73]. The tumor suppressor p53 and its family members, p63 and p73, are potent repressors of $h T E R T$ transcription as transient overexpression of these factors in 
human embryonic kidney cells results in lower c-Myc expression and consequently attenuated $h T E R T$ promoter activity [88].

Conversely, the activity of the positive regulators of c-Myc-induced $h T E R T$ activation may be counteracted by a variety of c-Myc inhibitors and suppressors. A major player is Mad, a potent antagonist of c-Myc, whose mechanism of action involves competing with c-Myc for E-box protein binding sites found in transcription regulatory regions of their target genes (see below for the discussion on the role Mad plays in repressing hTERT). In addition, the lipid ceramide was shown to destabilize c-Myc protein via ubiquitination of the transcription factor, resulting in the downregulation of hTERT expression [45]. Other factors were shown to disrupt c-Myc binding to hTERT promoter and its transcription activation: Breast cancer 1 (BRCA1) associates with c-Myc via its N-terminal domain and depletes $h T E R T$ promoter-bound c-Myc in ovarian, prostate and breast cancer cells [81,82]. Cyclin-Dependent Kinase Inhibitor P27 (p27KIP1) interferes with c-Myc binding to $h T E R T$ promoter in malignant glioma cells [206]. Hypoxia-Inducible Factor 1-alpha (HIF-1 $\alpha)$ downregulates c-Myc-mediated activation of $h T E R T$ promoter activity in colorectal carcinoma cells [77]. Mothers Against Decapentaplegic Homolog 3 (Smad3), upon Transforming Growth Factor beta (TGF $\beta$ ) induction, interacts with c-Myc which leads to the downregulation of $h T E R T$ promoter activity [79,80]. TGF $\beta$ has also been shown to inhibit $h T E R T$ expression by upregulating Snail expression in human embryonic kidney (HEK) cells and keratinocyte cells [80]. Wilms Tumor 1 (WT1) downregulates $h T E R T$ transcription in clear cell renal cell carcinoma (ccRCC) by directly binding to $h T E R T$ promoter or by repressing c-Myc expression via its promoter activity [35]. Gastrokine 1 (GKN1) was reported to inhibit $h T E R T$ expression in gastric cancer cells by binding directly to c-Myc and downregulating its expression, leading to lower hTERT promoter activity [207]. The compound arsenic trioxide (ATO) was previously shown to downregulate telomerase activity and this was recently shown to involve the downregulation of four transcription activators of $h T E R T$, one of which is c-Myc [101]. Knockdown of c-Myc (or the other factors) via siRNA could sensitize promyelocytic leukemia cells to ATO-induced apoptosis and inhibition of cell growth.

Despite the strong evidences brought forth by the various studies above regarding the key role c-Myc plays in the modulation of $h T E R T$ expression and telomerase activity, several studies involving the use of primary tumor samples have proven the lack of correlation between c-Myc expression and $h T E R T$ mRNA levels, specifically in hepatocellular carcinoma and breast carcinoma tissue samples [208,209]. Consistent with this notion, while c-Myc is one of the four transcription factors used for iPS cell reprogramming, it is non-essential [210].

\subsubsection{NF- $\mathrm{KB}$}

NF- $\mathrm{kB}$ is a transcription factor complex whose activity is induced in many cell types by various stimuli such as inflammation, cellular differentiation, tumorigenesis, and apoptosis. It is shown to play an activating role in telomerase expression and activity by regulating $h T E R T$ gene transcription via binding to the proximal promoter of the target gene, or indirectly by modulating the expression of transcription factors known to affect $h T E R T$ expression. The activation of NF- $\mathrm{B}$ in primary bovine aortic endothelial cells (BAECs) and neuroepithelioma cell line via exposure to ionizing gamma radiation, and in human monocyte cells undergoing inflammation, leads to increased binding of NF- $\kappa B$ to $h T E R T$ promoter and consequently enhanced telomerase activity $[147,148,152]$. Depleting NF- $\kappa B$ levels by ectopically expressing NFKB Inhibitor Alpha $(\mathrm{I} \kappa \mathrm{B} \alpha)$ or by disrupting the binding of NF-kB to $h T E R T$ promoter by eliminating its response element compromises the radiation- and lesion-induced upregulation of $h T E R T$ expression NF- $\mathrm{B}$-mediated activation of telomerase was also shown to be crucial in the recovery of intimal smooth muscle cells upon vascular injury in mediating intimal hyperplasia [57]. It was also proposed that there exists a feed-forward regulation between NF- $\mathrm{B}$ and telomerase as the latter was found to bind to p65, a component of NF- $\mathrm{B}$, and modulate its transcription activity on its target genes, including factors which are important for inflammation and cancer progression [211,212]. The NF- $\kappa B$ response element in $h T E R T$ promoter is located more 
than $600 \mathrm{bp}$ upstream of the translation start site, however, recently, the non-canonical NF- $\mathrm{kB}$ pathway was implicated in tumorigenesis specifically via a hotspot $h T E R T$ promoter mutation-C250T-which creates a binding motif for E-twenty-six (ETS) protein, a transcription activator of $h T E R T$ gene. Binding of ETS to the newly formed response element is not enough to activate $h T E R T$ transcription; it requires an activated non-canonical NF- $\mathrm{KB}$ signaling background to drive this transcription [213]. The NF- $\mathrm{KB}$ subunit, p52, is recruited to the C250T site and binds to its own half site and this facilitates the stimulation of $h T E R T$ transcription in the cancer cells.

As mentioned, NF- $\mathrm{KB}$ can also activate $h T E R T$ expression via an indirect way. It is known to activate strong $h T E R T$ transcription activators such as c-Myc and Sp1 in a number of human cell lines $[58,64]$. Besides the ones described above, other naturally occurring and synthetic chemicals were shown to modulate NF-kB-mediated activation of $h T E R T$ transcription. The plant-derived molecule, curcumin, and the drug, pelitinib, were both shown to potently inhibit NF-kB-induced $h T E R T$ activation by ionizing radiation in neurogenic cancer and tongue squamous cell carcinoma cells, respectively $[148,153]$. In addition, arsenic trioxide (ATO) was found to repress the expression of NF- $\mathrm{KB}$ (and other transcription factors namely Sp1, c-Myc and Upstream Transcription Factor 2 (USF2)) in human promyelocytic leukemia cells and reduce the transcription of $h T E R T$ [101].

\subsubsection{STAT Proteins}

STAT3 plays a key regulatory role in the expression of $h T E R T$ in several cancer cell lines including gastric, breast and glioblastoma, and $h T E R T$ in turn contributes to the survival of these STAT3-dependent tumors. When STAT3 expression levels were reduced in a hepatocellular carcinoma (HCC) cell line using siRNA, $h T E R T$ expression was consequently reduced [214]. Studies involving breast cancer stem cells revealed that STAT3 binds to and activates $h T E R T$ promoter in concert with Cluster of Differentiation 44 (CD44) and NF-KB, and that diminished levels of STAT3 resulted in the downregulation of $h T E R T$ expression [149]. Mechanistically, STAT3-mediated upregulation of $h T E R T$ expression may be the result of the following biological factors: leptin induction in breast cancer and HCC cells [71,188], miR-21 expression in glioblastoma cells [191], and core protein of hepatitis C virus (HCVc) in HCC cells [192]. STAT3-mediated upregulation of $h T E R T$ expression by HCVc also involves the action of DNA Methyltransferase 1 (DNMT1) which facilitates the methylation of $h T E R T$ promoter.

STAT5 has been shown to bind directly to a distal promoter region of $h T E R T$ in a chronic myelogenous leukaemia (CML) cell line and an adult T-cell leukaemia (ATL) cell line, resulting in the activation of telomerase expression [193,194]. The positive effect STAT5 has on $h T E R T$ expression was also seen in primary leukemic cells upon Interleukin 2 (IL-2) induction and has been attributed to the phosphorylation of STAT5 which permits its interaction with Janus-activated kinase (JAK)-1 and -2. Depletion of STAT5 via the introduction of specific siRNA was shown to lead to the inhibition of IL-2-induced $h T E R T$ activation [193]. However, STAT5 was also reported to indirectly activate $h T E R T$ through c-Myc, another transcription activator of $h T E R T$. In two different leukemic cell lines, erythropoietin (EPO) was proven to be a potent activator of telomerase and this was shown to be via the induction of the JAK2/STAT5/c-Myc axis, and in turn was negatively regulated by TGF $\beta / \mathrm{Smad} 3$ signaling [195,196].

\subsubsection{Paired Box Proteins (Pax)}

Pax protein family consists of paired box- and homeobox-containing transcription factors which play a crucial role in early development. Two of its members were shown to bind to regions proximal to $h T E R T$ translational start site and activate its transcription. In lymphocyte cell lines, PAX5 was found to bind to two sites, one each in exon 1 and 2 of $h T E R T$ gene [156]. Knockdown via siRNA and overexpression of PAX5 lead to increased and decreased $h T E R T$ expression, respectively. Furthermore, these effects were reported to be independent of CCCTC-binding factor (CTCF) and promoter methylation. On the other hand, PAX8 was revealed to bind to four sites upstream of the 
hTERT translational start site in glioma cells [157]. Interestingly, PAX8 was also shown to bind and activate hTR promoter, which fortifies the role of PAX8 in the regulation of telomerase activity.

\subsubsection{Estrogen Receptor}

Estrogen receptor is a nuclear hormone receptor which binds to estrogen response elements (ERE) upon stimulation by its ligand. $h T E R T$ transcription and telomerase activity are found to be activated by estradiol (E2) in ER-positive cells but not in ER-negative ones [215]. However, artificial expression of ER in ER-negative cells was found to result in $h T E R T$ transcription activation and increased telomerase activity. In vitro DNA-protein binding assays revealed that ER $\alpha$ specifically binds to two EREs in the $h T E R T$ promoter $[51,116,118]$. In addition, several biomolecules were shown to inhibit ER activation of hTERT in human cancer cells. Treatment of breast cancer cells with indole-3-carbonol (I3C) [121], colon cancer cells with 15-deoxy- $\Delta 12,14$-prostaglandin J2 (15d-PGJ2) [84], ovarian cancer cells with $\mathrm{miR}-498$ [120], and breast and endometrial cancer cells with progesterone [122], were reported to result in the suppression of ER-induced activation of $h T E R T$ expression.

\subsection{Transcription Repressors of hTERT}

\subsubsection{Mad1}

Mad1 is an antagonist of Myc protein in that it competes with the latter for E-box motif binding in promoter region of target genes and mediates the repression (as opposed to Myc's activation) of these genes. The binding of Mad1 to $h T E R T$ proximal promoter is mediated by an $\mathrm{N}$-terminal domain which is responsible for its interaction with its co-repressor, Sin3A [139]. This binding can be reversed by overexpression of Myc in mortal WI38 cells [86]. The Mad1-induced hTERT repression has clinical significance in patients suffering from myelodysplastic syndrome (MDS) as these individuals, especially those with more favorable outcomes, show higher expression levels of Mad1 as compared to healthy controls [216]. The authors of the report went on to propose that Mad1 plays an important role in reducing $h T E R T$ expression during the early stage of the disease. Thus, it is not surprising that a number of publications have focused on the effects of various molecules on Mad1-mediated repression of $h T E R T$ promoter. For example, 4-[3-(1-adamanyly)-4-hydroxyphenyl]-3-chlorocinnamic acid (3-C1-AHPC), an adamantyl-related molecule, has been shown to inhibit the expression of miR-202, which targets Mad1 gene, and hence lead to de-repression of $h T E R T$ gene and increased telomerase activity [140]. The repressive role of the 3-C1-AHPC/miR-202/Mad1 axis on hTERT expression was supported by the observation that the overexpression of pre-miR-202 and inhibition of miR-202 resulted in the decreased and increased repressive activity of Mad1 on $h T E R T$ expression, respectively. In addition, EGCG (a green tea polyphenol), sulforaphane (SFN), 15d-PGJ2 (15-deoxy-delta-12,14-prostaglandin J2), selenium, and 12-O-tetradecanoylphorbol-13-acetate have been shown to enhance Mad1's binding to and repression of $h$ TERT promoter $[85,108,139,217,218]$.

\subsubsection{Sp3}

Sp3 is a GC-box-binding protein with an antagonistic function to Sp1. Sp3, together with Sp1, has been shown to bind to a recognition site in the proximal promoter of $h T E R T$, resulting in the repression of the gene. This binding is important but not sufficient to govern $h T E R T$ expression; chromatin environment, such as histone modification patterns, is also essential [219]. In fact, several studies have reported that the binding of Sp3 to hTERT proximal promoter leads to the recruitment of a histone deacetylase (HDAC), HDAC1, to the promoter region and, in turn, modifies the epigenetic landscape of the region, resulting in the silencing of the $h T E R T$ gene [186]. This repression can be reversed by overexpression of dominant-negative form of Sp3. On the other hand, ceramide is known to enhance the Sp3/HDAC-mediated suppression of the hTERT gene [174]. This involves the ceramide-induced deacetylation of $\mathrm{Sp} 3$, an active form of the protein with higher binding capacity 
to $h T E R T$ promoter, and a decrease in RNA polymerase II recruitment to the promoter due to lower histone acetylation levels in the region. Ceramide has also been shown to reduce Sp1 binding to the $h T E R T$ promoter, thus abrogating its activating effect on $h T E R T$ transcription [174]. However, it is worth noting that a study has posited that $\mathrm{Sp} 1$, but not Sp3, plays a regulatory role in telomerase activity in Jurkat $\mathrm{T}$ cells, as Sp3 overexpression in these cells did not cause a significant change in hTERT mRNA levels or telomerase activity [220].

\subsubsection{CTCF}

CTCF is chromatin-binding factor which affects transcription of numerous genes. It mostly acts as a transcription repressor but is known to activate the transcription of several genes. The binding of CTCF to the first exon of the $h T E R T$ gene was reported to suppress its expression in telomerase-negative cells but not in cancer cells [105]. It preferentially binds to unmethylated sites of the $h T E R T$ regulatory region. The treatment of telomerase-positive cells with a strong demethylating agent (5-azadC) led to the reactivation of CTCF binding to its response element and repression of $h T E R T$ expression. This observation was supported by another study whose results showed that the introduction of sulforaphane (SFN), a potent histone deacetylase inhibitor, in human breast cancer cells resulted in CpG demethylation and hyperacetylation of the region proximal to the first exon of $h T E R T$ and this facilitated the binding of $h T E R T$ repressors, such as MAD1 and CTCF, in this region [108]. Conversely, siRNA-induced knockdown of CTCF was sufficient to partially reverse the inhibitory effect of SFN on $h T E R T$ transcription. In addition to binding to the first exon of $h T E R T, C T C F$ was also found to negatively modulate $h T E R T$ expression by binding to an enhancer element approximately $4.5 \mathrm{~kb}$ upstream of the $h T E R T$ transcription start site and this was confirmed by chromosome conformation capture (3C) assay [221].

\subsubsection{E2F1}

E2F1 is a transcription factor which binds to E2 recognition sites found in the promoter of numerous genes, especially those involved in cell cycle regulation and DNA damage response. It has also been shown to play a direct role in the transcription regulation of $h T E R T$ in human squamous cell carcinoma cells by binding to and modulating $h T E R T$ proximal promoter [110]. The overexpression of wildtype E2F1, but not its mutant, has been shown to downregulate $h T E R T$ promoter activity and telomerase activity. The effect of E2F1 on $h T E R T$ promoter has been proposed to counteract the activating effect of c-Myc on the regulatory region [100] and act downstream of the TGF $\beta$ signaling pathway as the expression of a dominant negative form of E2F1 resulted in the abrogation of the TGF $\beta$-induced $h T E R T$ inhibition [111].

\subsubsection{Hormone Nuclear Receptors}

Vitamin $\mathrm{D}(3)$ receptor (VDR) is the nuclear receptor for 1,25-dihydroxyvitamin $\mathrm{D}(3)$ (VD3) and it can form a heterodimer with another nuclear receptor, retinoid $X$ receptor (RXR), whose ligand is 9-cis-retinoic acid (9-cis-RA). In prostate cancer cells, this heterodimer was found to bind directly to a region approximately $2.5 \mathrm{~kb}$ upstream of $h T E R T$ translation start site and repress the expression of the gene [203]. In vivo experiments involving xenografts in nude mice recapitulated the inhibitory effects of this protein heterodimer on $h T E R T$ transcription. However, another report has argued against the direct role of VDR on $h T E R T$ transcription repression. Instead, it was proposed that the inhibitory effect of VD3 stems from its suppression of $h T E R T$ mRNA by destabilizing it [222]. This was supported by independent studies in ovarian, endometrial and breast cancer cells where VD3 was shown to repress $h T E R T$ expression through the induction of miR-498, which in turn targets the $3^{\prime}$ untranslated region (3' UTR) of $h T E R T$ transcripts and thus decreases its expression [120,223].

Another nuclear receptor that has a repressive effect on $h T E R T$ transcription is androgen receptor (AR). Treatment of prostate cancer cells with AR agonist resulted in the inhibition of $h T E R T$ promoter activity and, conversely, treatment of AR antagonist failed to recapitulate this inhibition [33]. On top 
of that, the expression of a mutant form of AR (T877A) not only broadens ligand specificity but also precluded its binding to the $h T E R T$ promoter.

\subsection{Transcription Regulators with Dual Roles}

\subsubsection{Specificity Protein $1(\mathrm{Sp} 1)$}

$\mathrm{Sp} 1$ is a transcription factor that binds to GC-box motifs in the promoter of its target gene and regulates its expression, either activating or repressing the transcription process depending on cellular context. Sp1 is known to activate $h T E R T$ gene expression in telomerase-positive cells but suppresses it in telomerase-negative ones. It does this by binding to five GC-box motifs found in the proximal promoter of $h T E R T$ [46,165]. Mutation of these binding sites results in the attenuation of Sp1-mediated $h T E R T$ activation or repression in various cell lines. However, the expression and $h T E R T$ promoter-binding of Sp1 alone is insufficient to drive the desired effect. Epigenetic environment, especially the presence of suitable histone marks, is crucial in actualising these effects.

In telomerase-positive cells, particularly cancer cells, Sp1 may activate $h T E R T$ expression on its own or in conjunction with specific co-activators. Sp1 may work cooperatively with c-Myc and bind their respective response elements in $h T E R T$ proximal promoter to upregulate the transcription of the gene [46,53]. In fact, in the various cell lines examined, expression of Sp1 and c-Myc correlates positively with $h T E R T$ transcription activity. Kaposi's sarcoma-associated herpesvirus (KSHV) latent protein, latency-associated nuclear antigen (LANA), was also found to bind directly to Sp1 in KSHV-infected body-cavity-based lymphoma (BCBL) cells and enhance the binding of Sp1 to its cognate binding sites in the $h T E R T$ proximal promoter $[165,166]$. In HeLa cells, the human T cell leukaemia virus type 1 protein, HTLV-1 bZIP factor (HBZ), forms heterodimers with JunD and this complex interacts with Sp1 at the $h T E R T$ promoter region and causes the activation of the target gene [36]. In addition, MBD1-Containing Chromatin-Associated Factor 1 (MCAF1) was shown to interact with Sp1 and the general transcription machinery in HeLa cells and facilitate $h T E R T$ expression [168]. Nuclear Factor Of Activated T-Cells 1 (NFAT1) can bind to hTERT proximal promoter at a site flanked by two GC-boxes and this allows for the synergistic interaction between NFAT1 and Sp1, resulting in the activation of $h T E R T$ transcription [154]. In human liver carcinoma cells, High Mobility Group AT-Hook 2 (HMGA2) binds to Sp1 and disrupts the recruitment of histone deacetylase (HDAC) to the promoter of $h T E R T$ and this leads to an increase in the expression of the gene [170]. This observation was recapitulated in cells treated with suberoylanilide hydroxamide (SAHA), a HDAC inhibitor. Numerous other factors and molecules have been shown to facilitate Sp1-mediated upregulation of $h T E R T$ gene expression in various cell lines (refer to Table 1 for a comprehensive list), and many others have been reported to play a repressive role instead. Notable inhibitors of Sp1-mediated activation of $h T E R T$ promoter activity include the tumor suppressor p53 [171,224] and its family members p63 and p73 [88,172,173], the key transcription factor E2F-1 [176 Beitzinger, 2006 \#55], and the cell cycle checkpoint proteins p27Kip1 [93] and p16 [225].

As alluded to earlier, epigenetic environment is important in Sp1-mediated regulation of hTERT gene. The epigenetic mechanism behind the repression of $h T E R T$ gene expression in telomerase-negative human somatic cells is particularly well-characterized. Sp1 binds to its cognate binding motifs found in the $h T E R T$ proximal promoter and recruits HDAC proteins to this region $[183,226]$. The deacetylation of histone subunits leads to the silencing of the $h T E R T$ gene. This transcription repression may be reversed by treating the cells with trichostatin A (TSA), a HDAC inhibitor [226,227]. TSA-induced activation of $h T E R T$ was shown to be enhanced by the overexpression of Sp1 [227] or HDAC1 [226], or the mutation of the Sp1 binding sites [226,227]. In contrast, TGF- $\beta$-activated kinase 1 (TAK1) has the ability to facilitate the recruitment of HDAC to Sp1 on $h T E R T$ promoter and suppress $h T E R T$ activation in human lung adenocarcinoma cells [185]. 


\subsubsection{Activator Protein 1 (AP-1)}

AP-1 is a transcription factor complex which consists of components belonging to the c-Jun, c-Fos, Activating Transcription Factor (ATF) and J Domain-Containing Protein (JDP) families. Its effect on $h T E R T$ transcription has been contentious. It was initially reported to repress $h T E R T$ expression in HeLa cells, where the transient overexpression of its components (c-Fos and c-Jun or c-Fos and JunD) strongly represses $h T E R T$ promoter activity [34]. This suppression was found to be mediated by the binding of the heterodimer to two regions upstream of the $h T E R T$ translation start site. Mutation of these binding sites led to the abrogation of the repressive effect of AP-1 on $h T E R T$. On the other hand, ectopic expression of the viral protein HBZ and JunD in HeLa cells was shown to activate $h T E R T$ promoter [36]. This involves the interaction of HBZ/JunD heterodimer with the co-activator Sp1 and their binding to GC-rich motifs in the $h T E R T$ promoter.

\subsubsection{Early growth response-1 (EGR-1)}

EGR-1 is a transcription factor whose activity is crucial for mitogenesis and cellular differentiation. The effect of this protein on $h T E R T$ transcription is two-fold-it can act as an activator and also a repressor depending on the tissue of origin. Ectopic expression of EGR-1 in villous cancer cells led to an increase in $h T E R T$ expression, both in the mRNA and protein levels [114]. This effect was shown to be mediated by the direct binding of the protein to a single site in the proximal promoter region of $h T E R T$. Furthermore, expression of EGR-1 was found to correlate with that of $h T E R T$ during trophoblastic development and in patients with preeclampsia. On the contrary, the examination of mRNA levels in primary cervical cancer tissues revealed a negative correlation between the expression of EGR-1 and that of $h T E R T$. Further studies involving epidermoid carcinoma and squamous cell carcinoma cell lines supported this observation-overexpression of EGR-1 resulted in the suppression of $h T E R T$ expression [115]. These results showcased the important role EGR-1 plays in the regulation of $h T E R T$ gene transcription.

\subsubsection{Hypoxia-inducible factor 2-alpha (HIF-2 $\alpha)$}

HIF- $2 \alpha$ is a transcription factor which is involved in cellular oxygen regulation. Unlike another hypoxia-inducible factor, HIF-1, whose regulatory effect on $h T E R T$ gene is solely positive, HIF- $2 \alpha$ plays dual role in modulating $h T E R T$ expression. In several renal carcinoma cell lines tested, HIF- $2 \alpha$ overexpression led to an increase in $h T E R T$ promoter activity and its depletion resulted in lower hTERT mRNA levels [134]. This positive effect is mediated by the direct binding of HIF-2 $\alpha$ to $h T E R T$ proximal promoter and the recruitment of p300 and histone acetyltransferase to the regulatory site. In contrast, ectopic expression of HIF- $2 \alpha$ in three glioma cell lines led to repression of hTERT gene expression [134]. This suggests that HIF- $2 \alpha$ may play different roles in $h T E R T$ gene regulation in different cellular context.

\subsubsection{Kruppel-like family of transcription factors (KLF) Proteins}

KLFs are a group of proteins which share a common structure, namely a C-terminal domain consisting of three zinc finger configurations. The human genome contains $17 \mathrm{KLF}$ family genes and they may act as activators or repressors of their target genes. Two of the members of the KLF family proteins are known to play opposite roles in the regulation of $h T E R T$ expression. KLF2 was shown to bind to a putative site in the first exon of the $h T E R T$ gene in resting $\mathrm{T}$ cells, resulting in the repression of the latter [136]. However, upon activation of these cells, KLF2 dissociates from the regulatory element and this relieves the gene of its repression. In contrast, KLF4, a key pluripotency marker, and mediator, was found to activate $h T E R T$ expression in telomerase-negative, alternative lengthening of telomere (ALT) cells and human fibroblast cells via direct binding to a response element in the proximal promoter region of $h T E R T$ [137]. Conversely, knocking down KLF4 in telomerase-positive cancer and stem cells abrogated $h T E R T$ expression significantly. Furthermore, telomerase expression was found 
to be sufficient in replacing KLF4 function in the maintenance of self-renewal in human embryonic stem cells, showcasing that hTERT is one of the primary targets of KLF4 in stem cell maintenance. Interestingly, a recent study revealed that the knockdown of $h T E R T$ via shRNA in HeLa cells led to a decrease in KLF4 expression [228]. This shows that the interplay between the expression of KLF4 and hTERT is a complex and important one.

\subsubsection{Nuclear Transcription Factor X Box-Binding Protein 1 (NFX1)}

NFX1 is traditionally known as a transcription repressor. It plays a key role in determining the duration of inflammatory response via its interaction with and transcription regulation of the promoter of MHC class II genes. Three isoforms of NFX1 have been identified and two of these have opposite roles in the regulation of $h T E R T$ gene expression. NFX1-123, with c-Myc as a co-activator, was shown to bind to an X-box motif located adjacent to a known E-box motif, the canonical response element of c-Myc and other E-box proteins, and activate hTERT promoter activity [48]. In contrast, NFX1-91 represses $h T E R T$ expression by binding to the same X-box motif and recruiting Sin3A and histone deacetylases (HDACs) to the proximal promoter of $h T E R T$ [48]. This repressive effect can be reversed by the expression of the human papillomavirus (HPV) viral protein E6, which facilitates the ubiquitination and degradation of the NFX1-91 isoform, or by knocking down NFX1-91. Thus, alternative splicing of the NFX1 transcript plays an important role in the expression of $h T E R T$ gene in human fetal kidney cells.

\subsubsection{Upstream stimulatory factors (USF) Proteins}

USFs are a group of proteins belonging to the basic helix-loop-helix leucine zipper protein family. They function as transcription regulators and are known to bind to E-box motifs found in regulatory elements of their target genes. USF1 and USF2 have been shown to play both activating and repressive roles in the regulation of $h T E R T$ gene expression. USF1/2 heterodimers were found to bind directly to E-box motifs found on the proximal promoter of $h T E R T$ in both telomerase-positive and -negative cells. However, they specifically activate $h T E R T$ expression only in telomerase-positive cells [200]. This positive effect was shown to be mediated by p300, which acts as a co-activator, and p38 MAP kinase, a known activator of USF activity. In stark contrast, two other reports posited that USF1 and USF2 act as suppressors of $h T E R T$ expression in telomerase-positive oral squamous cancer cells and E6-expressing immortalized cells [54,202]. This was evident by the downregulation and upregulation of E6-mediated $h T E R T$ expression upon the forced expression and siRNA-induced knockdown of the USF genes, respectively. Moreover, binding of USF1 and USF2 to the proximal E-box motif in the hTERT promoter diminishes in cells expressing E6 and this is accompanied by an increase in c-Myc binding to the same site [54]. Interestingly, yet another group proposed that the effect USF2 has on hTERT expression is dependent on the relative abundance of the splice isoforms in the cells. They showed that both full-length and truncated forms of USF2 can bind to the hTERT proximal E-box. However, the latter has a dominant-negative effect on the former, therefore depleting the full-length isoform and abrogating its activating effect on $h T E R T$ expression [201]. This concurs with the finding that the N-terminally truncated isoform is only present in telomerase-negative resting lymphocytes but not in telomerase-positive activated lymphocytes [201].

\subsection{Epigenetic Modifiers Regulating hTERT Transcription}

Differentiation of pluripotent stem cells is accompanied by the downregulation of $h T E R T$ expression. hTERT promoter is eventually silenced when the cells are terminally differentiated. On the other hand, reprogramming of somatic cells to induced pluripotent stem cells results in the activation of $h T E R T$ expression. The epigenetic regulation of $h T E R T$ promoter plays an important role in these two opposite $h T E R T$ transcriptional states. The following section will focus on the known modes of epigenetic regulation of $h T E R T$ expression including methylation of $h T E R T$ promoter, histone modifications, and modulation by sirtuins and non-coding RNAs. However, it remains unclear 
how $h T E R T$ expression is differentially regulated during cancer development, cellular differentiation and reprogramming.

\subsubsection{Histone Modifiers}

In telomerase-positive cells, telomerase expression is associated with hyperacetylation of histone $\mathrm{H} 3$ and $\mathrm{H} 4$ and methylation of lysine- 4 of histone $\mathrm{H} 3$, whereas in telomerase-negative cells (ALT cells), the silencing of the expression of telomerase is associated with hypoacetylation of $\mathrm{H} 3$ and $\mathrm{H} 4$ and methylation of lysine-9 of histone H3 [229]. Induction of the tumor suppressor, AT-Rich Interaction Domain 1A (ARID1A), increases occupancy of H3K9me3 at transcription start site (TSS) of hTERT and decreases acetylated lysine-12 of histone H4 (H4K12Ac) levels at this site. Treatment of telomerase negative cells with histone deacetylase inhibitor (HDACi), trichostatin A (TSA), could activate transcription of $h T E R T$ gene [229].TSA was shown to inhibit deacetylation of histone H3 lysine-9 or -14, leading to upregulated $h T E R T$ expression in umbilical cord mesenchymal stem cells as well [230]. Sirtuin protein family consists of seven homologs of yeast Sir2 protein which is known to be involved in a plethora of biological processes including aging [231], stress response, and tumorigenesis [232]. SIRT1, also known as nicotinamide adenine dinucleotide (NAD)-dependent deacetylase sirtuin-1, was shown to deacetylate c-Myc [233]. Deacetylated c-Myc displays enhanced association with Max, an essential partner for its activation [227], and this, in turn activates $h T E R T$ expression [233]. Knocking down SIRT1 leads to decreased expression of genes targeted by c-Myc including $h T E R T$. These findings have been recapitulated by other groups with additional mechanism. Deletion of SIRT1 leads to significant reduction in telomerase expression, thus causing telomere dysfunction-induced foci and nuclear abnormality $[234,235]$. The same group found that deletion of SIRT1 is associated with substantial induction of acetylated lysine-9 of histone H3 (H3K9Ac) and reduction in trimethylated H3K9 at hTERT promoter [235]. In addition, SET and MYND Domain-Containing Protein 3 (SMYD3) knockdown in colorectal carcinoma and hepatocellular carcinoma cells was found to diminish the occupancy of c-Myc at $h T E R T$ promoter via reduction in $\mathrm{H} 3 \mathrm{~K} 4$ trimethylation and histone $\mathrm{H} 3$ acetylation.

\subsubsection{Regulators of $h T E R T$ Promoter Methylation}

DNA methylation is involved in gene silencing $[236,237]$. The $h T E R T$ promoter region contains clusters of $\mathrm{CpG}$ islands with dense GC-rich regions. This suggests that DNA methylation may play a role in the regulation of $h T E R T$ expression [238]. However, recent reports suggested that there is little or no methylation around the $h T E R T$ transcription start site (TSS) in most cancer cell lines and embryonic stem cells $[239,240]$. Consistent with these results, demethylation of CpG by demethylating agent 5aza-2'-deoxycytidine (5azadC) is not associated with increased $h T E R T$ expression in cancer cells $[105,227,241,242]$. In summary, there is an inconclusive correlation between DNA methylation and telomerase regulation. Information on the detailed results for different tissues, and regions of $h T E R T$ promoter, data interpretation, and categorization, and the DNA methylation detection methods is summarized in Table 2. 
Table 2. Detail of studies which reported methylation status of human telomerase reverse transcriptase $(h T E R T)$ promoter proximal region.

\begin{tabular}{|c|c|c|c|c|}
\hline Region Tested & $\begin{array}{l}\text { Methylation } \\
\text { Status }\end{array}$ & Cell Line/Tissue & $\begin{array}{l}\text { Technique to Detect } \\
\text { Methylation }\end{array}$ & Reference \\
\hline-500 to +50 (72 CpG sites) & Complete & Telomerase-positive (CMV, SUSM-1) & $\begin{array}{l}\text { Bisulfite genomic } \\
\text { sequencing }\end{array}$ & [238] \\
\hline-500 to +50 (72 CpG sites) & Partial & $\begin{array}{l}\text { Telomerase-positive (HTB 182, HTB178, } \\
\text { CaLu1, CaLu3, CaLu6, HTB57, HCT 116) }\end{array}$ & $\begin{array}{l}\text { Bisulfite genomic } \\
\text { sequencing }\end{array}$ & [238] \\
\hline-500 to +50 (72 CpG sites) & Unmethylated & $\begin{array}{l}\text { Telomerase-positive (A549, HTB183) and } \\
\text { telomerase-negative (NHF, MRC-5 p27) }\end{array}$ & $\begin{array}{l}\text { Bisulfite genomic } \\
\text { sequencing }\end{array}$ & [238] \\
\hline Promoter region & Unmethylated & $\begin{array}{l}\text { Telomerase-negative (WI38, HA-1 pre-crisis } \\
\text { cell strain, JFCF-6T /5K pre-crisis cell strain, } \\
\text { IMR90, BJ fibroblast, telomerase-negative } \\
\text { adrenal carcinoma) and } \\
\text { telomerase-positive (CT1485) }\end{array}$ & $\begin{array}{l}\text { Methylation-specific } \\
\text { PCR-based assay }\end{array}$ & [243] \\
\hline Promoter region & Partial or complete & $\begin{array}{l}\text { U2OS, GM847, VA13, telomerase-negative } \\
\text { breast carcinoma, Co1310 }\end{array}$ & $\begin{array}{l}\text { Methylation-specific } \\
\text { PCR-based assay }\end{array}$ & [243] \\
\hline $\begin{array}{l}-441 \text { to }+218 \text {; with respect } \\
\text { to ATG ( } 27 \text { CpG sites) }\end{array}$ & Hypermethylated & $\begin{array}{l}\text { Telomerase-positive (MCF-7, A431, HeLa, } \\
\text { Co115, HT29, SW480, HS520, SW2, PC3, } \\
\text { Saos-2, U2-OS) and two paraffin-embedded } \\
\text { fixed tumor tissue (colon, kidney) }\end{array}$ & $\begin{array}{l}\text { Bisulfite genomic } \\
\text { sequencing }\end{array}$ & [244] \\
\hline-100 and +100 & $\begin{array}{l}75 \% \text { to } 100 \% \\
\text { methylated }\end{array}$ & $\begin{array}{l}\text { HeLa, SW480, } 8 \text { clones from tumor tissues } \\
\text { (breast, bladder and cervix) }\end{array}$ & $\begin{array}{l}\text { Bisulfite genomic } \\
\text { sequencing }\end{array}$ & [105] \\
\hline-100 and +100 & Partial & Telomerase-negative( BJ, HLF) & $\begin{array}{l}\text { Bisulfite genomic } \\
\text { sequencing }\end{array}$ & [105] \\
\hline-80 to -165 & Unmethylated & $\begin{array}{l}\text { Telomerase-positive (HeLa, SW480) and } \\
\text { telomerase negative (BJ, HLF) }\end{array}$ & $\begin{array}{l}\text { Bisulfite genomic } \\
\text { sequencing }\end{array}$ & [105] \\
\hline $\begin{array}{l}\text { Promoter region } \\
\text { (27 CpG sites) }\end{array}$ & Unmethylated & $\begin{array}{l}\text { Downregulated } h T E R T \text { expression in } \\
\text { HCC samples }\end{array}$ & $\begin{array}{l}\text { Bisulfite genomic } \\
\text { sequencing }\end{array}$ & [239] \\
\hline $\begin{array}{l}\text { Upstream of the } \\
\text { transcription start } \\
\text { site (UTSS) }\end{array}$ & $\begin{array}{l}\text { Hypermethylated } \\
\text { ( } 5 \text { sites })\end{array}$ & Malignant pediatric brain tumor samples & Methylation arrays & [245] \\
\hline $\begin{array}{l}\text { Upstream of the } \\
\text { transcription start } \\
\text { site (UTSS) }\end{array}$ & $\begin{array}{l}\text { Densely } \\
\text { methylated }\end{array}$ & Neuroblastoma samples & Methylation arrays & [246] \\
\hline
\end{tabular}

\subsection{Monoallelic Expression of hTERT Gene}

Several cancer cell lines contain point mutations in only one of its $h T E R T$ alleles, specifically in its promoter region (see below for a detailed discussion of $h T E R T$ promoter mutations and their effect on $h T E R T$ expression). This is attributed to the reversal of $h T E R T$ gene silencing on the one active allele while the other one remains silenced. The promoter of the active gene was found to be decorated by the permissive histone $\mathrm{H} 3 \mathrm{~K} 4 \mathrm{me} 2 / 3$ mark, while the promoter of the silenced gene showed higher deposition of H3K27me3, a histone mark indicating transcriptionally repressed heterochromatin regions [247]. Concomitant to this epigenetic switch in the $h T E R T$ promoter region, the point mutation allows for the binding of the transcription factor GA Binding Protein Transcription Factor Alpha and -Beta 1(GABPA/B1) heterodimer to the newly created site, which in turn facilitates the recruitment of RNA Polymerase II to the promoter, resulting in the transcription of $h T E R T$ gene. 


\subsection{Complexity of Trans-Regulation of hTERT Gene Transcription}

It is clear from the multitude of evidence presented above that $h T E R T$ transcription regulation is complex. It involves the interplay between the various components of molecular and cellular biology. This is not surprising given the crucial role telomerase plays in the maintenance of stem cell and cellular transformation. Despite the wealth of knowledge in the roles transcription factors and epigenetic modifiers play in the regulation of $h T E R T$ expression, a lot more has to be done to elucidate the mechanism underlying the switching off and on of $h T E R T$ gene during cellular differentiation and cellular reprogramming, and during cellular transformation, respectively.

\section{Genetic Alterations Regulating hTERT Transcription}

Recent advances in DNA sequencing technologies have enabled large-scale genome sequencing studies across various tumor types. Many alterations in protein-coding genes have been identified $[248,249]$. On the other hand, only a handful of the mutations in non-coding regions have been recently identified [250]. Recurrent mutations and chromosomal rearrangements in hTERT promoter have further confirmed the importance of telomerase activation in human cancers $[251,252]$.

\section{1. hTERT Promoter Mutations}

Transcriptional regulation at the level of $h T E R T$ promoter mutations first came into attention with the discovery of highly recurrent mutations in this region in melanomas. In particular, two hotspot $\mathrm{C}>\mathrm{T}$ point mutations were observed at the nucleotide position $124 \mathrm{bp}$ and $146 \mathrm{bp}$ upstream of the translation start codon (ATG) and these specific mutations were termed C228T and C250T, respectively. Other less common mutations were also detected in the $h T E R T$ promoter region such as the CC > TT mutations at $-124 /-125$ and $-138 /-139$ positions. The observation that the frequency of mutations detected in $h T E R T$ promoter is higher than those in the B-Raf Proto-Oncogene Serine/Threonine-Protein Kinase (BRAF) gene, and that the presence of highly recurrent point mutations in just two nucleotide positions strongly suggests that these are driver mutations which play key roles at various stages of tumorigenesis in melanoma [251,252].These important findings have provided new insights into a possible mechanism for $h T E R T$ activation in human cancers. In addition, the discovery of driver alterations in the non-coding portion of the human cancer genome was a novel advancement in understanding the role of mutated non-coding sequences in transcriptional deregulation and tumorigenesis.

\subsection{1. hTERT Promoter Mutations in Different Types of Human Cancers}

Since the publication of the studies mentioned above, there has been a surge in interest in investigating the frequency of $h T E R T$ promoter mutations in melanomas and other types of cancers, particularly at the two hotspot locations, C228T and C250T (Figure 2). To date, hTERT promoter mutations have been evaluated in more than 60 tumor types and they are found to be the most common point mutations in hepatocellular carcinoma [253,254], glioblastoma [253], bladder cancer [255] and melanoma [251,252]. 


\section{Figure 2a}

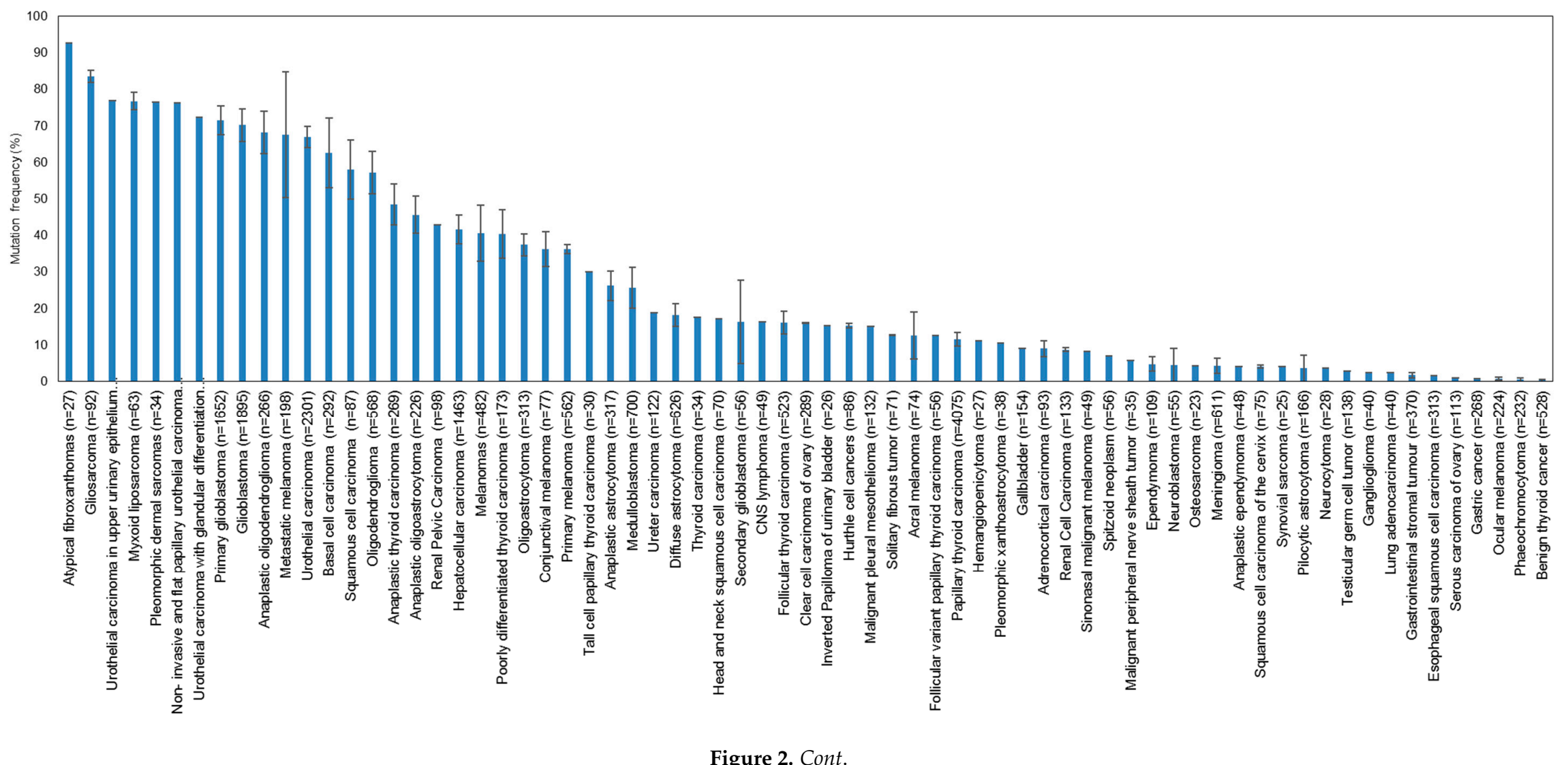

Figure 2. Cont. 


\section{Figure 2b}

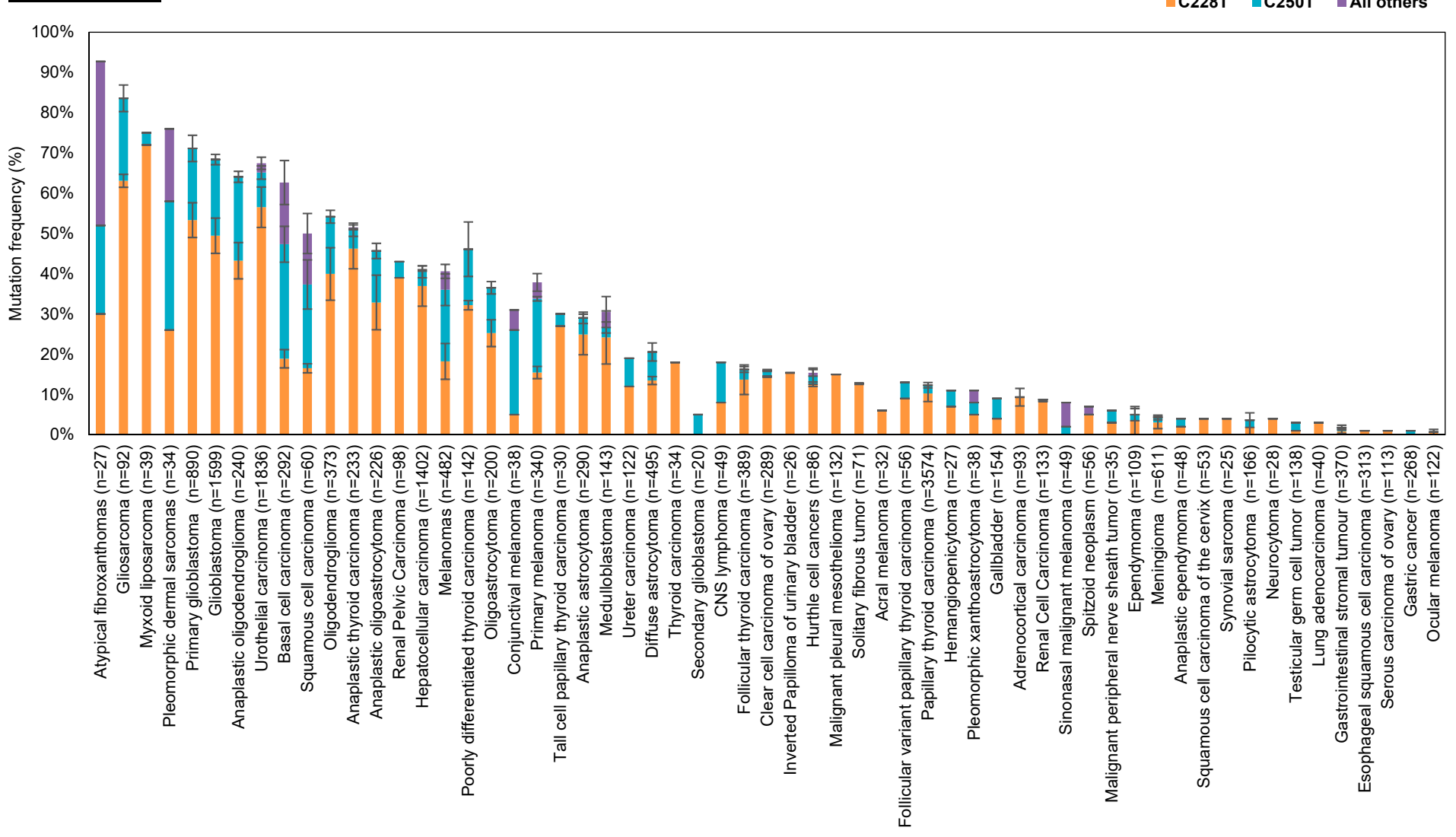

Figure 2. Frequency of human telomerase reverse transcriptase ( $h T E R T)$ promoter mutations in various cancer types. (a) Overall $h T E R T$ promoter mutation frequencies of various cancer types plotted in descending order; (b) Overall $h T E R T$ promoter mutation frequencies of various cancer types with breakdown of individual frequencies of C228T, C250T, and all other mutations. The overall mutation frequencies of $h T E R T$ promoter were compiled from all relevant publications on human cancer genome sequencing. The label " $n$ " corresponds to the total number of tumors sequenced among different studies for the same tumor type. Error bars correspond to the standard errors in mutation frequencies calculated among different studies on the same tumor type. Only studies with at least 20 samples sequenced were included in this study. Only studies which provided the detailed breakdown of different mutation sites were included in (b). Refer to Table 3 for the list of references used to compile this figure. 
Table 3. List of publications reporting $h T E R T$ promoter mutation frequency in the various cancer types.

\begin{tabular}{|c|c|}
\hline Cancer type & References \\
\hline Atypical fibroxanthomas & [256] \\
\hline Gliosarcoma & [257-259] \\
\hline Urothelial carcinoma in upper urinary epithelium & [260] \\
\hline Myxoid liposarcoma & {$[253,261]$} \\
\hline Pleomorphic dermal sarcomas & [256] \\
\hline Non- invasive and flat papillary urothelial carcinoma & [255] \\
\hline Urothelial carcinoma with glandular differentiation & [262] \\
\hline Primary glioblastoma & {$[253,259,260,263-268]$} \\
\hline Glioblastoma & {$[260,269-278]$} \\
\hline Anaplastic oligodendroglioma & {$[253,259,264,270,272,278]$} \\
\hline Metastatic melanoma & {$[252,279]$} \\
\hline Urothelial carcinoma & {$[253,255,260,262,269-271,280-289]$} \\
\hline Basal cell carcinoma & [290-293] \\
\hline Squamous cell carcinoma & {$[290,291,294]$} \\
\hline Oligodendroglioma & {$[259,264,265,268,270,272,276-278,295]$} \\
\hline Anaplastic thyroid carcinoma & {$[296-301]$} \\
\hline Anaplastic oligoastrocytoma & {$[259,264,278]$} \\
\hline Renal Pelvic Carcinoma & {$[284,302]$} \\
\hline Hepatocellular carcinoma & {$[253,254,260,303-307]$} \\
\hline Melanomas & {$[251,270,271,292,308,309]$} \\
\hline Poorly differentiated thyroid carcinoma & {$[297,299,301]$} \\
\hline Oligoastrocytoma & {$[264,268,276-278,310]$} \\
\hline Conjunctival melanoma & {$[311,312]$} \\
\hline Primary melanoma & {$[252,279,313,314]$} \\
\hline Tall cell papillary thyroid carcinoma & [315] \\
\hline Anaplastic astrocytoma & {$[253,259,264,278,310]$} \\
\hline Medulloblastoma & {$[253,259,316,317]$} \\
\hline Ureter carcinoma & [302] \\
\hline Diffuse astrocytoma & {$[259,260,264,270,272,277,310,318]$} \\
\hline Thyroid carcinoma & [271] \\
\hline Head and neck squamous cell carcinoma & [276] \\
\hline Secondary glioblastoma & [263] [259] \\
\hline CNS lymphoma & [319] \\
\hline Follicular thyroid carcinoma & {$[270,296,299,300,320-323]$} \\
\hline Clear cell carcinoma of ovary & {$[324,325]$} \\
\hline Inverted Papilloma of urinary bladder & [287] \\
\hline Hurthle cell cancers & {$[297,326]$} \\
\hline Malignant pleural mesothelioma & [327] \\
\hline Solitary fibrous tumor & {$[261,328]$} \\
\hline Acral melanoma & {$[279,329]$} \\
\hline Follicular variant papillary thyroid carcinoma & {$[315]$} \\
\hline Papillary thyroid carcinoma & {$[270,296,297,299,300,315,320,322,323,330-338]$} \\
\hline Hemangiopenicytoma & [259] \\
\hline Pleomorphic xanthoastrocytoma & [259] \\
\hline Gallbladder & [339] \\
\hline Adrenocortical carcinoma & {$[285,340,341]$} \\
\hline Renal Cell Carcinoma & [342] \\
\hline Sinonasal malignant melanoma & [343] \\
\hline Spitzoid neoplasm & [344] \\
\hline Malignant peripheral nerve sheath tumor & [261] \\
\hline Ependymoma & {$[253,259]$} \\
\hline Neuroblastoma & {$[253,340]$} \\
\hline Osteosarcoma & [253] \\
\hline Meningioma & {$[253,259,260,345,346]$} \\
\hline Anaplastic ependymoma & [259] \\
\hline Squamous cell carcinoma of the cervix & {$[253,325]$} \\
\hline Synovial sarcoma & [261] \\
\hline
\end{tabular}


Table 3. Cont.

\begin{tabular}{cc}
\hline Cancer type & References \\
\hline Pilocytic astrocytoma & {$[259,272]$} \\
Neurocytoma & {$[259]$} \\
Testicular germ cell tumor & {$[347]$} \\
Ganglioglioma & {$[259]$} \\
Lung adenocarcinoma & {$[271]$} \\
Gastrointestinal stromal tumor & {$[260,270,340,348,349]$} \\
Esophageal squamous cell carcinoma & {$[350]$} \\
Serous carcinoma of ovary & {$[325]$} \\
Gastric cancer & {$[339]$} \\
Ocular melanoma & {$[270,311,312,351]$} \\
Phaeochromocytoma & {$[340,341]$} \\
Benign thyroid cancer & {$[270,296,299,321,332,333]$} \\
\hline
\end{tabular}

Cancer types that have high overall mutation frequency generally correspond to tumors arising from cells with low turnover rate such as neurons, fibroblasts, glial cells and hepatocytes (Figure 2a). This observation concurs with previously published results that showed that $h T E R T$ promoter mutations occur most frequently in cancers that originate in tissues with low self-renewal rates [253]. Based on the $h T E R T$ promoter mutation studies conducted so far, it is tantalizing to hypothesize that cancer subtypes without $h T E R T$ promoter mutations may derive from tissues with tissue-specific stem cells as they already display high telomerase expression and therefore do not require $h T E R T$ promoter mutations to further upregulate telomerase expression to sustain telomere maintenance. In contrast, cells with lower $h T E R T$ expression levels and low turnover rates might selectively acquire $h T E R T$ promoter mutations during tumorigenesis to upregulate telomerase levels and avoid replicative senescence. We further examined the distribution of the two hotspot mutations (C228T and C250T) across the different tumor types (Figure $2 b$ ) and observed that the mutation frequency ratio of C228T:C250T is markedly lower in cancers of the cutaneous tissues such as basal cell carcinomas, squamous cell carcinoma and melanoma.

\subsubsection{Mechanism by Which $h T E R T$ Promoter Mutations Leads to Enhanced Telomerase Levels}

The hotspot mutations mentioned earlier create a CCGGAA/T binding motif for ETS (E-twenty six) transcription factors whose recruitment to these sites may result in increased $h T E R T$ expression. This is facilitated by the activation of non-canonical NF- $\mathrm{kB}$ signaling pathway which provides a co-activator, in the form of p52, to enhance the transcription activity of the $h T E R T$ promoter [213] (see above for a more comprehensive discussion of the molecular mechanism). Reporter assays carried out to assess the functional impact of these promoter mutations showed a two- to four-fold increase in $h T E R T$ promoter activity in melanomas [251,252].

\subsection{Chromosomal Rearrangements and hTERT Expression}

A recent study involving neuroblastoma tumors posited the significance of genomic rearrangements in telomerase activation specifically in the high-risk bracket of this tumor type [246]. They discovered from their analysis of whole-genome sequencing data that neuroblastoma tumors displayed breakpoint clusters at four genomic loci and one of them is at the $5 p 15.33$ region where $h T E R T$ gene is located. These chromosomal rearrangements were found to consistently cluster in the region about $50 \mathrm{~kb}$ upstream of the $h T E R T$ transcription initiation site, but at the same time leave the coding and core promoter region intact. They showed that these chromosomal alterations result in the juxtaposition of $h T E R T$ gene to strong enhancer regions, resulting in major changes in the epigenetic landscape of the affected region. These changes, in turn, lead to the abrogation of $h T E R T$ gene silencing engendered by repressive histone modification and DNA methylation states. 


\section{Conclusions}

Herein, we have summarized the numerous transcription activators and repressors that were found to interact with the hTERT core promoter. However, it is still unclear how hTERT is silenced during stem cell differentiation as well as reactivated during somatic cell reprogramming. These processes are likely to involve a host of these transcription regulators in a cell context-dependent manner. In addition, they are likely to be controlled by epigenetic changes accompanying these cellular events. The contribution of specific transcription modulators in these processes remains to be explored and elucidated. Given the complexity of the regulatory network, it is perhaps more meaningful to approach the issue from a wider perspective by studying the network system as a whole instead of focusing on individual players.

The identification of $h T E R T$ promoter mutations, on the other hand, may provide interesting biomarkers for diagnosis and prognosis of various cancer types. Since the publication of the abovementioned landmark papers, many studies have subsequently explored the potential application of these mutations as biomarkers. To date, the existence of $h T E R T$ promoter mutations has been associated with decreased survival in patients suffering from melanoma [279,292], bladder cancer [280,352], urogenital cancer [280,325], glioma [274], medulloblastoma [316], thyroid cancer [299,300,330], and laryngeal tumors [353].

As shown in Figure 2, urothelial carcinoma samples display up to $67 \%$ mean mutation frequency $(n=2301)$ in the $h$ TERT promoter region, specifically at the two hotspots, making it the most frequently mutated gene identified so far in this region. Hence, these hTERT promoter mutations have the potential to become a good biomarker for clinicians to conduct early detection of bladder cancer and subsequent follow-up tests for cancer progression or recurrence in patients. In hepatocellular carcinomas, about $42 \%$ mean mutation frequency $(n=1463)$ in the $h T E R T$ promoter region was observed. Similarly, their high prevalence suggests that these hotspot mutations may be utilized as candidate biomarkers for early detection and monitoring. Lastly, the high prevalence of $h T E R T$ promoter mutations in various subtypes of gliomas also suggest that the mutations can serve as useful biomarkers to aid in classification and prognostication via extraction of samples from cerebrospinal fluid. Further studies to confirm such a causal relation in various tumor types will be necessary before genome-based clinical classifications based on $h T E R T$ promoter mutations can find their way into the clinics.

Activation of telomerase enzyme is classified as one of the classic hallmarks of cancer as it confers cells with replicative immortality [354]. Hence, blocking the activity of telomerase is an active area of research in cancer therapeutics. Previous strategies to block telomerase activity in cancer patients have focused on the use of immunotherapy, gene therapy, small molecular inhibitors and G-quadruplex ligands, of which some have entered clinical trials [355]. However, such targeting strategies can also result in non-specific inhibition of telomerase activity in tissue progenitor/stem cells, which may limit the utilization of such telomerase inhibitors in the long run. As we find out more about the mechanism of how $h T E R T$ promoter is activated or repressed, novel strategies to therapeutically target telomerase can be developed. For instance, new specific small molecular inhibitors may be developed to interfere with the binding of ETS/TCF transcription factors to the CCGGAA/T binding motif that is only present in cancer cells that carry the specific C228T or C250T mutation. In addition, as mentioned above, the presence of $h T E R T$ promoter mutation in a tumor may be used as a biomarker to predict subsequent clinical response to a telomerase inhibitor drug.

Acknowledgments: All sources of funding of the study should be disclosed. Please clearly indicate grants that you have received in support of your research work. Clearly state if you received funds for covering the costs to publish in open access.

Conflicts of Interest: The authors declare no conflict of interest. 


\section{References}

1. Blackburn, E.H. Telomere states and cell fates. Nature 2000, 408, 53-56. [CrossRef] [PubMed]

2. De Lange, T. How shelterin solves the telomere end-protection problem. Cold Spring Harb. Symp. Quant. Biol. 2010, 75, 167-177. [CrossRef] [PubMed]

3. Makarov, V.L.; Hirose, Y.; Langmore, J.P. Long G tails at both ends of human chromosomes suggest a C strand degradation mechanism for telomere shortening. Cell 1997, 88, 657-666. [CrossRef]

4. Wright, W.E.; Tesmer, V.M.; Huffman, K.E.; Levene, S.D.; Shay, J.W. Normal human chromosomes have long G-rich telomeric overhangs at one end. Genes Dev. 1997, 11, 2801-2809. [CrossRef] [PubMed]

5. Feng, J.; Funk, W.D.; Wang, S.S.; Weinrich, S.L.; Avilion, A.A.; Chiu, C.P.; Adams, R.R.; Chang, E.; Allsopp, R.C.; Yu, J.; et al. The RNA component of human telomerase. Science 1995, 269, $1236-1241$. [CrossRef] [PubMed]

6. Nakamura, T.M.; Morin, G.B.; Chapman, K.B.; Weinrich, S.L.; Andrews, W.H.; Lingner, J.; Harley, C.B.; Cech, T.R. Telomerase catalytic subunit homologs from fission yeast and human. Science 1997, 277, 955-959. [CrossRef] [PubMed]

7. Kim, N.W.; Piatyszek, M.A.; Prowse, K.R.; Harley, C.B.; West, M.D.; Ho, P.L.; Coviello, G.M.; Wright, W.E.; Weinrich, S.L.; Shay, J.W. Specific association of human telomerase activity with immortal cells and cancer. Science 1994, 266, 2011-2015. [CrossRef] [PubMed]

8. Masutomi, K.; Yu, E.Y.; Khurts, S.; Ben-Porath, I.; Currier, J.L.; Metz, G.B.; Brooks, M.W.; Kaneko, S.; Murakami, S.; DeCaprio, J.A.; et al. Telomerase maintains telomere structure in normal human cells. Cell 2003, 114, 241-253. [CrossRef]

9. Wright, W.E.; Piatyszek, M.A.; Rainey, W.E.; Byrd, W.; Shay, J.W. Telomerase activity in human germline and embryonic tissues and cells. Dev. Genet. 1996, 18, 173-179. [CrossRef]

10. Levy, M.Z.; Allsopp, R.C.; Futcher, A.B.; Greider, C.W.; Harley, C.B. Telomere end-replication problem and cell aging. J. Mol. Biol. 1992, 225, 951-960. [CrossRef]

11. De Lange, T.; Lundblad, V.; Blackburn, E.H. Telomeres, 2nd ed.; Cold Spring Harbor Laboratory Press: Plainview, NY, USA, 2005; p. 576.

12. Harley, C.B.; Futcher, A.B.; Greider, C.W. Telomeres shorten during ageing of human fibroblasts. Nature 1990, 345, 458-460. [CrossRef] [PubMed]

13. Takai, H.; Smogorzewska, A.; de Lange, T. DNA damage foci at dysfunctional telomeres. Curr. Biol. 2003, 13, 1549-1556. [CrossRef]

14. d'Adda di Fagagna, F.; Reaper, P.M.; Clay-Farrace, L.; Fiegler, H.; Carr, P.; Von Zglinicki, T.; Saretzki, G.; Carter, N.P.; Jackson, S.P. A DNA damage checkpoint response in telomere-initiated senescence. Nature 2003, 426, 194-198. [CrossRef] [PubMed]

15. Kaul, Z.; Cesare, A.J.; Huschtscha, L.I.; Neumann, A.A.; Reddel, R.R. Five dysfunctional telomeres predict onset of senescence in human cells. EMBO Rep. 2012, 13, 52-59. [CrossRef] [PubMed]

16. Hayflick, L.; Moorhead, P.S. The serial cultivation of human diploid cell strains. Exp. Cell Res. 1961, 25, 585-621. [CrossRef]

17. Flores, I.; Canela, A.; Vera, E.; Tejera, A.; Cotsarelis, G.; Blasco, M.A. The longest telomeres: A general signature of adult stem cell compartments. Genes Dev. 2008, 22, 654-667. [CrossRef] [PubMed]

18. Artandi, S.E.; DePinho, R.A. Telomeres and telomerase in cancer. Carcinogenesis 2010, 31, 9-18. [CrossRef] [PubMed]

19. Schaetzlein, S.; Lucas-Hahn, A.; Lemme, E.; Kues, W.A.; Dorsch, M.; Manns, M.P.; Niemann, H.; Rudolph, K.L. Telomere length is reset during early mammalian embryogenesis. Proc. Natl. Acad. Sci. USA 2004, 101, 8034-8038. [CrossRef] [PubMed]

20. Holohan, B.; Wright, W.E.; Shay, J.W. Cell biology of disease: Telomeropathies: An emerging spectrum disorder. J. Cell Biol. 2014, 205, 289-299. [CrossRef] [PubMed]

21. Armanios, M.; Blackburn, E.H. The telomere syndromes. Nat. Rev. Genet. 2012, 13, 693-704. [CrossRef] [PubMed]

22. Lansdorp, P.M. Telomeres and disease. EMBO J. 2009, 28, 2532-2540. [CrossRef] [PubMed]

23. Blasco, M.A.; Lee, H.W.; Hande, M.P.; Samper, E.; Lansdorp, P.M.; DePinho, R.A.; Greider, C.W. Telomere shortening and tumor formation by mouse cells lacking telomerase rna. Cell 1997, 91, 25-34. [CrossRef] 
24. Lee, H.W.; Blasco, M.A.; Gottlieb, G.J.; Horner, J.W., II; Greider, C.W.; DePinho, R.A. Essential role of mouse telomerase in highly proliferative organs. Nature 1998, 392, 569-574. [PubMed]

25. Chou, W.C.; Chen, H.Y.; Yu, S.L.; Cheng, L.; Yang, P.C.; Dang, C.V. Arsenic suppresses gene expression in promyelocytic leukemia cells partly through Sp1 oxidation. Blood 2005, 106, 304-310. [CrossRef] [PubMed]

26. Shay, J.W.; Bacchetti, S. A survey of telomerase activity in human cancer. Eur. J. Cancer 1997, 33, 787-791. [CrossRef]

27. Smith, L.L.; Coller, H.A.; Roberts, J.M. Telomerase modulates expression of growth-controlling genes and enhances cell proliferation. Nat. Cell Biol. 2003, 5, 474-479. [CrossRef] [PubMed]

28. Cong, Y.S.; Wen, J.; Bacchetti, S. The human telomerase catalytic subunit hTERT: Organization of the gene and characterization of the promoter. Hum. Mol. Genet. 1999, 8, 137-142. [CrossRef] [PubMed]

29. Horikawa, I.; Cable, P.L.; Afshari, C.; Barrett, J.C. Cloning and characterization of the promoter region of human telomerase reverse transcriptase gene. Cancer Res. 1999, 59, 826-830. [PubMed]

30. Takakura, M.; Kyo, S.; Kanaya, T.; Hirano, H.; Takeda, J.; Yutsudo, M.; Inoue, M. Cloning of human telomerase catalytic subunit ( $h T E R T)$ gene promoter and identification of proximal core promoter sequences essential for transcriptional activation in immortalized and cancer cells. Cancer Res. 1999, 59, 551-557. [PubMed]

31. Takahashi, K.; Tanabe, K.; Ohnuki, M.; Narita, M.; Ichisaka, T.; Tomoda, K.; Yamanaka, S. Induction of pluripotent stem cells from adult human fibroblasts by defined factors. Cell 2007, 131, 861-872. [CrossRef] [PubMed]

32. Yu, J.; Vodyanik, M.A.; Smuga-Otto, K.; Antosiewicz-Bourget, J.; Frane, J.L.; Tian, S.; Nie, J.; Jonsdottir, G.A.; Ruotti, V.; Stewart, R.; et al. Induced pluripotent stem cell lines derived from human somatic cells. Science 2007, 318, 1917-1920. [CrossRef] [PubMed]

33. Moehren, U.; Papaioannou, M.; Reeb, C.A.; Grasselli, A.; Nanni, S.; Asim, M.; Roell, D.; Prade, I.; Farsetti, A.; Baniahmad, A. Wild-type but not mutant androgen receptor inhibits expression of the $h T E R T$ telomerase subunit: A novel role of AR mutation for prostate cancer development. FASEB J. 2008, 22, 1258-1267. [CrossRef] [PubMed]

34. Takakura, M.; Kyo, S.; Inoue, M.; Wright, W.E.; Shay, J.W. Function of AP-1 in transcription of the telomerase reverse transcriptase gene (TERT) in human and mouse cells. Mol. Cell. Biol. 2005, 25, 8037-8043. [CrossRef] [PubMed]

35. Sitaram, R.T.; Degerman, S.; Ljungberg, B.; Andersson, E.; Oji, Y.; Sugiyama, H.; Roos, G.; Li, A. Wilms' tumour 1 can suppress $h$ TERT gene expression and telomerase activity in clear cell renal cell carcinoma via multiple pathways. Br. J. Cancer 2010, 103, 1255-1262. [CrossRef] [PubMed]

36. Kuhlmann, A.S.; Villaudy, J.; Gazzolo, L.; Castellazzi, M.; Mesnard, J.M.; Duc Dodon, M. HTLV-1 HBZ cooperates with jund to enhance transcription of the human telomerase reverse transcriptase gene $(h T E R T)$. Retrovirology 2007. [CrossRef] [PubMed]

37. Deng, W.G.; Jayachandran, G.; Wu, G.; Xu, K.; Roth, J.A.; Ji, L. Tumor-specific activation of human telomerase reverses transcriptase promoter activity by activating enhancer-binding Protein-2 $\beta$ in human lung cancer cells. J. Biol. Chem. 2007, 282, 26460-26470. [CrossRef] [PubMed]

38. Fu, L.; Chen, W.; Guo, W.; Wang, J.; Tian, Y.; Shi, D.; Zhang, X.; Qiu, H.; Xiao, X.; Kang, T.; et al. Berberine targets AP-2/hTERT, NF- $\mathrm{B} / \mathrm{COX}-2, \mathrm{HIF}-1 \alpha / \mathrm{VEGF}$ and cytochrome-c/caspase signaling to suppress human cancer cell growth. PLoS ONE 2013, 8, e69240. [CrossRef] [PubMed]

39. Suryo Rahmanto, Y.; Jung, J.G.; Wu, R.C.; Kobayashi, Y.; Heaphy, C.M.; Meeker, A.K.; Wang, T.L.; Shih Ie, M. Inactivating arid1a tumor suppressor enhances TERT transcription and maintains telomere length in cancer cells. J. Biol. Chem. 2016, 291, 9690-9699. [CrossRef] [PubMed]

40. Hoffmeyer, K.; Raggioli, A.; Rudloff, S.; Anton, R.; Hierholzer, A.; Del Valle, I.; Hein, K.; Vogt, R.; Kemler, R. $\mathrm{Wnt} / \beta$-catenin signaling regulates telomerase in stem cells and cancer cells. Science 2012, 336, 1549-1554. [CrossRef] [PubMed]

41. Zhang, Y.; Toh, L.; Lau, P.; Wang, X. Human telomerase reverse transcriptase (hTERT) is a novel target of the Wnt/ $\beta$-catenin pathway in human cancer. J. Biol. Chem. 2012, 287, 32494-32511. [CrossRef] [PubMed]

42. Isenmann, S.; Cakouros, D.; Zannettino, A.; Shi, S.; Gronthos, S. hTERT transcription is repressed by Cbfa1 in human mesenchymal stem cell populations. J. Bone Miner. Res. 2007, 22, 897-906. [CrossRef] [PubMed]

43. Wu, K.J.; Grandori, C.; Amacker, M.; Simon-Vermot, N.; Polack, A.; Lingner, J.; Dalla-Favera, R. Direct activation of TERT transcription by c-Myc. Nat. Genet. 1999, 21, 220-224. [PubMed] 
44. Xu, D.; Popov, N.; Hou, M.; Wang, Q.; Bjorkholm, M.; Gruber, A.; Menkel, A.R.; Henriksson, M. Switch from Myc/Max to Mad1/Max binding and decrease in histone acetylation at the telomerase reverse transcriptase promoter during differentiation of HL60 cells. Proc. Natl. Acad. Sci. USA 2001, 98, 3826-3831. [CrossRef] [PubMed]

45. Ogretmen, B.; Kraveka, J.M.; Schady, D.; Usta, J.; Hannun, Y.A.; Obeid, L.M. Molecular mechanisms of ceramide-mediated telomerase inhibition in the a549 human lung adenocarcinoma cell line. J. Biol. Chem. 2001, 276, 32506-32514. [CrossRef] [PubMed]

46. Kyo, S.; Takakura, M.; Taira, T.; Kanaya, T.; Itoh, H.; Yutsudo, M.; Ariga, H.; Inoue, M. Sp1 cooperates with c-Myc to activate transcription of the human telomerase reverse transcriptase gene (hTERT). Nucleic Acids Res. 2000, 28, 669-677. [CrossRef] [PubMed]

47. Veldman, T.; Liu, X.; Yuan, H.; Schlegel, R. Human papillomavirus E6 and Myc proteins associate in vivo and bind to and cooperatively activate the telomerase reverse transcriptase promoter. Proc. Natl. Acad. Sci. USA 2003, 100, 8211-8216. [CrossRef] [PubMed]

48. Gewin, L.; Myers, H.; Kiyono, T.; Galloway, D.A. Identification of a novel telomerase repressor that interacts with the human papillomavirus type-16 E6/E6-AP complex. Genes Dev. 2004, 18, 2269-2282. [CrossRef] [PubMed]

49. Faiola, F.; Liu, X.; Lo, S.; Pan, S.; Zhang, K.; Lymar, E.; Farina, A.; Martinez, E. Dual regulation of c-Myc by p300 via acetylation-dependent control of Myc protein turnover and coactivation of Myc-induced transcription. Mol. Cell. Biol. 2005, 25, 10220-10234. [CrossRef] [PubMed]

50. Wang, Y.W.; Chang, H.S.; Lin, C.H.; Yu, W.C. HPV-18 E7 conjugates to c-Myc and mediates its transcriptional activity. Int. J. Biochem. Cell Biol. 2007, 39, 402-412. [CrossRef] [PubMed]

51. Kyo, S.; Takakura, M.; Kanaya, T.; Zhuo, W.; Fujimoto, K.; Nishio, Y.; Orimo, A.; Inoue, M. Estrogen activates telomerase. Cancer Res. 1999, 59, 5917-5921. [PubMed]

52. Xu, D.; Dwyer, J.; Li, H.; Duan, W.; Liu, J.P. Ets2 maintains hTERT gene expression and breast cancer cell proliferation by interacting with c-Myc. J. Biol. Chem. 2008, 283, 23567-23580. [CrossRef] [PubMed]

53. Oh, S.T.; Kyo, S.; Laimins, L.A. Telomerase activation by human papillomavirus type 16 E6 protein: Induction of human telomerase reverse transcriptase expression through Myc and GC-rich Sp1 binding sites. J. Virol. 2001, 75, 5559-5566. [CrossRef] [PubMed]

54. McMurray, H.R.; McCance, D.J. Human papillomavirus type 16 E6 activates TERT gene transcription through induction of c-Myc and release of USF-mediated repression. J. Virol. 2003, 77, 9852-9861. [CrossRef] [PubMed]

55. Liu, X.; Dakic, A.; Zhang, Y.; Dai, Y.; Chen, R.; Schlegel, R. HPV E6 protein interacts physically and functionally with the cellular telomerase complex. Proc. Natl. Acad. Sci. USA 2009, 106, 18780-18785. [CrossRef] [PubMed]

56. Li, H.; Lee, T.H.; Avraham, H. A novel tricomplex of BRCA1, Nmi, and c-Myc inhibits c-Myc-induced human telomerase reverse transcriptase gene (hTERT) promoter activity in breast cancer. J. Biol. Chem. 2002, 277, 20965-20973. [CrossRef] [PubMed]

57. Bu, D.X.; Johansson, M.E.; Ren, J.; Xu, D.W.; Johnson, F.B.; Edfeldt, K.; Yan, Z.Q. Nuclear factor \{kappa\}B-mediated transactivation of telomerase prevents intimal smooth muscle cell from replicative senescence during vascular repair. Arterioscler. Thromb. Vasc. Biol. 2010, 30, 2604-2610. [CrossRef] [PubMed]

58. Sinha-Datta, U.; Horikawa, I.; Michishita, E.; Datta, A.; Sigler-Nicot, J.C.; Brown, M.; Kazanji, M.; Barrett, J.C.; Nicot, C. Transcriptional activation of $h T E R T$ through the NF-kB pathway in HTLV-I-transformed cells. Blood 2004, 104, 2523-2531. [CrossRef] [PubMed]

59. Yamashita, S.; Ogawa, K.; Ikei, T.; Fujiki, T.; Katakura, Y. FOXO3a potentiates hTERT gene expression by activating c-Myc and extends the replicative life-span of human fibroblast. PLoS ONE 2014, 9, e101864. [CrossRef] [PubMed]

60. Ponnala, S.; Chetty, C.; Veeravalli, K.K.; Dinh, D.H.; Klopfenstein, J.D.; Rao, J.S. MMP-9 silencing regulates hTERT expression via $\beta 1$ integrin-mediated FAK signaling and induces senescence in glioma xenograft cells. Cell Signal 2011, 23, 2065-2075. [CrossRef] [PubMed]

61. Yang, H.; Ou, C.C.; Feldman, R.I.; Nicosia, S.V.; Kruk, P.A.; Cheng, J.Q. Aurora-a kinase regulates telomerase activity through c-Myc in human ovarian and breast epithelial cells. Cancer Res. 2004, 64, 463-467. [CrossRef] [PubMed] 
62. Yang, J.; Deng, X.; Deng, L.; Gu, H.; Fan, W.; Cao, Y. Telomerase activation by Epstein-Barr virus latent membrane protein 1 is associated with c-Myc expression in human nasopharyngeal epithelial cells. J. Exp. Clin. Cancer Res. 2004, 23, 495-506. [PubMed]

63. Endoh, T.; Tsuji, N.; Asanuma, K.; Yagihashi, A.; Watanabe, N. Survivin enhances telomerase activity via up-regulation of specificity protein 1- and c-Myc-mediated human telomerase reverse transcriptase gene transcription. Exp. Cell Res. 2005, 305, 300-311. [CrossRef] [PubMed]

64. Sheng, W.Y.; Chen, Y.R.; Wang, T.C. A major role of PKC $\theta$ and NFKB in the regulation of hTERT in human T lymphocytes. FEBS Lett. 2006, 580, 6819-6824. [CrossRef] [PubMed]

65. Liu, C.; Fang, X.; Ge, Z.; Jalink, M.; Kyo, S.; Bjorkholm, M.; Gruber, A.; Sjoberg, J.; Xu, D. The telomerase reverse transcriptase ( $h T E R T)$ gene is a direct target of the histone methyltransferase SMYD3. Cancer Res. 2007, 67, 2626-2631. [CrossRef] [PubMed]

66. Liu, X.; Vorontchikhina, M.; Wang, Y.L.; Faiola, F.; Martinez, E. Staga recruits mediator to the Myc oncoprotein to stimulate transcription and cell proliferation. Mol. Cell. Biol. 2008, 28, 108-121. [CrossRef] [PubMed]

67. Bermudez, Y.; Yang, H.; Cheng, J.Q.; Kruk, P.A. Pyk2/Erk 1/2 mediate Sp1- and c-Myc-dependent induction of telomerase activity by epidermal growth factor. Growth Factors 2008, 26, 1-11. [CrossRef] [PubMed]

68. Li, N.F.; Kocher, H.M.; Salako, M.A.; Obermueller, E.; Sandle, J.; Balkwill, F. A novel function of colony-stimulating factor 1 receptor in hTERT immortalization of human epithelial cells. Oncogene 2009, 28, 773-780. [CrossRef] [PubMed]

69. Bilsland, A.E.; Hoare, S.; Stevenson, K.; Plumb, J.; Gomez-Roman, N.; Cairney, C.; Burns, S.; Lafferty-Whyte, K.; Roffey, J.; Hammonds, T.; et al. Dynamic telomerase gene suppression via network effects of GSK3 inhibition. PLoS ONE 2009, 4, e6459. [CrossRef] [PubMed]

70. Sitaram, R.T.; Cairney, C.J.; Grabowski, P.; Keith, W.N.; Hallberg, B.; Ljungberg, B.; Roos, G. The PTEN regulator DJ-1 is associated with hTERT expression in clear cell renal cell carcinoma. Int. J. Cancer 2009, 125, 783-790. [CrossRef] [PubMed]

71. Stefanou, N.; Papanikolaou, V.; Furukawa, Y.; Nakamura, Y.; Tsezou, A. Leptin as a critical regulator of hepatocellular carcinoma development through modulation of human telomerase reverse transcriptase. BMC Cancer 2010. [CrossRef] [PubMed]

72. Niu, C.; Yip, H.K. Neuroprotective signaling mechanisms of telomerase are regulated by brain-derived neurotrophic factor in rat spinal cord motor neurons. J. Neuropathol. Exp. Neurol. 2011, 70, 634-652. [CrossRef] [PubMed]

73. Yamashita, S.; Ogawa, K.; Ikei, T.; Udono, M.; Fujiki, T.; Katakura, Y. SIRT1 prevents replicative senescence of normal human umbilical cord fibroblast through potentiating the transcription of human telomerase reverse transcriptase gene. Biochem. Biophys. Res. Commun. 2012, 417, 630-634. [CrossRef] [PubMed]

74. Adamo, R.; Comandini, A.; Aquino, A.; Bonmassar, L.; Guglielmi, L.; Bonmassar, E.; Franzese, O. The antiretroviral agent saquinavir enhances hTERT expression and telomerase activity in human T leukaemia cells in vitro. J. Exp. Clin. Cancer Res. 2013. [CrossRef] [PubMed]

75. Wang, X.; Zhou, P.; Sun, X.; Zheng, J.; Wei, G.; Zhang, L.; Wang, H.; Yao, J.; Lu, S.; Jia, P. Acidified bile acids increase hTERT expression via c-Myc activation in human gastric cancer cells. Oncol. Rep. 2015, 33, 3038-3044. [CrossRef] [PubMed]

76. Hrdlickova, R.; Nehyba, J.; Bose, H.R., Jr. Regulation of telomerase activity by interferon regulatory factors 4 and 8 in immune cells. Mol. Cell. Biol. 2009, 29, 929-941. [CrossRef] [PubMed]

77. Koshiji, M.; Kageyama, Y.; Pete, E.A.; Horikawa, I.; Barrett, J.C.; Huang, L.E. Hif-1alpha induces cell cycle arrest by functionally counteracting Myc. EMBO J. 2004, 23, 1949-1956. [CrossRef] [PubMed]

78. Cerezo, A.; Kalthoff, H.; Schuermann, M.; Schafer, B.; Boukamp, P. Dual regulation of telomerase activity through c-Myc -dependent inhibition and alternative splicing of hTERT. J. Cell Sci. 2002, 115, 1305-1312.

79. Li, H.; Xu, D.; Li, J.; Berndt, M.C.; Liu, J.P. Transforming growth factor beta suppresses human telomerase reverse transcriptase (hTERT) by Smad3 interactions with c-Myc and the hTERT gene. J. Biol. Chem. 2006, 281, 25588-25600. [CrossRef] [PubMed]

80. Yoo, Y.S.; Park, S.; Gwak, J.; Ju, B.G.; Oh, S. Involvement of transcription repressor snail in the regulation of human telomerase reverse transcriptase (hTERT) by transforming growth factor-beta. Biochem. Biophys. Res. Commun. 2015, 465, 131-136. [CrossRef] [PubMed] 
81. Xiong, J.; Fan, S.; Meng, Q.; Schramm, L.; Wang, C.; Bouzahza, B.; Zhou, J.; Zafonte, B.; Goldberg, I.D.; Haddad, B.R.; et al. Brca1 inhibition of telomerase activity in cultured cells. Mol. Cell. Biol. 2003, 23, 8668-8690. [CrossRef] [PubMed]

82. Zhou, C.; Liu, J. Inhibition of human telomerase reverse transcriptase gene expression by BRCA1 in human ovarian cancer cells. Biochem. Biophys. Res. Commun. 2003, 303, 130-136. [CrossRef]

83. Jang, K.J.; Kwon, G.S.; Jeong, J.W.; Kim, C.H.; Yoon, H.M.; Kim, G.Y.; Shim, J.H.; Moon, S.K.; Kim, W.J.; Choi, Y.H. Cordyceptin induces apoptosis through repressing hTERT expression and inducing extranuclear export of hTERT. J. Biosci. Bioeng. 2015, 119, 351-357. [CrossRef] [PubMed]

84. Moriai, M.; Tsuji, N.; Kobayashi, D.; Kuribayashi, K.; Watanabe, N. Down-regulation of $h T E R T$ expression plays an important role in 15-deoxy-delta12,14-prostaglandin J2-induced apoptosis in cancer cells. Int. J. Oncol. 2009, 34, 1363-1372. [PubMed]

85. Toaldo, C.; Pizzimenti, S.; Cerbone, A.; Pettazzoni, P.; Menegatti, E.; Daniela, B.; Minelli, R.; Giglioni, B.; Dianzani, M.U.; Ferretti, C.; et al. Ppargamma ligands inhibit telomerase activity and $h T E R T$ expression through modulation of the Myc /Mad/Max network in colon cancer cells. J. Cell. Mol. Med. 2010, 14, 1347-1357. [CrossRef] [PubMed]

86. Oh, S.; Song, Y.H.; Yim, J.; Kim, T.K. Identification of Mad as a repressor of the human telomerase (hTERT) gene. Oncogene 2000, 19, 1485-1490. [CrossRef] [PubMed]

87. Wahlstrom, T.; Belikov, S.; Arsenian Henriksson, M. Chromatin dynamics at the hTERT promoter during transcriptional activation and repression by c-Myc and Mnt in xenopus leavis oocytes. Exp. Cell Res. 2013, 319, 3160-3169. [CrossRef] [PubMed]

88. Yao, Y.; Bellon, M.; Shelton, S.N.; Nicot, C. Tumor suppressors p53, p63TA $\alpha$, p63TAy, p73 $\alpha$, and p73 $\beta$ use distinct pathways to repress telomerase expression. J. Biol. Chem. 2012, 287, 20737-20747. [CrossRef] [PubMed]

89. Gabet, A.S.; Mortreux, F.; Charneau, P.; Riou, P.; Duc-Dodon, M.; Wu, Y.; Jeang, K.T.; Wattel, E. Inactivation of hTERT transcription by tax. Oncogene 2003, 22, 3734-3741. [CrossRef] [PubMed]

90. Kitagawa, Y.; Kyo, S.; Takakura, M.; Kanaya, T.; Koshida, K.; Namiki, M.; Inoue, M. Demethylating reagent 5-azacytidine inhibits telomerase activity in human prostate cancer cells through transcriptional repression of hTERT. Clin. Cancer Res. 2000, 6, 2868-2875. [PubMed]

91. Grandjenette, C.; Schnekenburger, M.; Karius, T.; Ghelfi, J.; Gaigneaux, A.; Henry, E.; Dicato, M.; Diederich, M. 5-aza-2'-deoxycytidine-mediated c-Myc down-regulation triggers telomere-dependent senescence by regulating human telomerase reverse transcriptase in chronic myeloid leukemia. Neoplasia 2014, 16, 511-528. [CrossRef] [PubMed]

92. Grand, C.L.; Han, H.; Munoz, R.M.; Weitman, S.; Von Hoff, D.D.; Hurley, L.H.; Bearss, D.J. The cationic porphyrin Tmpyp4 down-regulates c-Myc and human telomerase reverse transcriptase expression and inhibits tumor growth in vivo. Mol. Cancer Ther. 2002, 1, 565-573. [PubMed]

93. Kanzawa, T.; Germano, I.M.; Kondo, Y.; Ito, H.; Kyo, S.; Kondo, S. Inhibition of telomerase activity in malignant glioma cells correlates with their sensitivity to temozolomide. Br. J. Cancer 2003, 89, 922-929. [CrossRef] [PubMed]

94. Jagadeesh, S.; Kyo, S.; Banerjee, P.P. Genistein represses telomerase activity via both transcriptional and posttranslational mechanisms in human prostate cancer cells. Cancer Res. 2006, 66, 2107-2115. [CrossRef] [PubMed]

95. Liao, C.H.; Hsiao, Y.M.; Hsu, C.P.; Lin, M.Y.; Wang, J.C.; Huang, Y.L.; Ko, J.L. Transcriptionally mediated inhibition of telomerase of fungal immunomodulatory protein from ganoderma tsugae in A549 human lung adenocarcinoma cell line. Mol. Carcinog. 2006, 45, 220-229. [CrossRef] [PubMed]

96. Pizzimenti, S.; Briatore, F.; Laurora, S.; Toaldo, C.; Maggio, M.; De Grandi, M.; Meaglia, L.; Menegatti, E.; Giglioni, B.; Dianzani, M.U.; et al. 4-hydroxynonenal inhibits telomerase activity and hTERT expression in human leukemic cell lines. Free Radic. Biol. Med. 2006, 40, 1578-1591. [CrossRef] [PubMed]

97. Yu, J.; Guo, Q.L.; You, Q.D.; Lin, S.S.; Li, Z.; Gu, H.Y.; Zhang, H.W.; Tan, Z.; Wang, X. Repression of telomerase reverse transcriptase mrna and $h T E R T$ promoter by gambogic acid in human gastric carcinoma cells. Cancer Chemother. Pharmacol. 2006, 58, 434-443. [CrossRef] [PubMed]

98. Moon, D.O.; Kim, M.O.; Lee, J.D.; Choi, Y.H.; Kim, G.Y. Butein suppresses c-Myc-dependent transcription and Akt-dependent phosphorylation of hTERT in human leukemia cells. Cancer Lett. 2009, 286, 172-179. [CrossRef] [PubMed] 
99. Huang, S.T.; Wang, C.Y.; Yang, R.C.; Chu, C.J.; Wu, H.T.; Pang, J.H. Wogonin, an active compound in Scutellaria baicalensis, induces apoptosis and reduces telomerase activity in the HL-60 leukemia cells. Phytomedicine 2010, 17, 47-54. [CrossRef] [PubMed]

100. Zhang, Y.; Zhang, A.; Shen, C.; Zhang, B.; Rao, Z.; Wang, R.; Yang, S.; Ning, S.; Mao, G.; Fang, D. E2F1 acts as a negative feedback regulator of c-Myc induced $h T E R T$ transcription during tumorigenesis. Oncol. Rep. 2014, 32, 1273-1280. [CrossRef] [PubMed]

101. Zhang, Y.; Sun, M.; Shi, W.; Yang, Q.; Chen, C.; Wang, Z.; Zhou, X. Arsenic trioxide suppresses transcription of hTERT through down-regulation of multiple transcription factors in HL-60 leukemia cells. Toxicol. Lett. 2015, 232, 481-489. [CrossRef] [PubMed]

102. Dasgupta, P.; Sengupta, S.B. Role of diallyl disulfide-mediated cleavage of c-Myc and Sp-1 in the regulation of telomerase activity in human lymphoma cell line U937. Nutrition 2015, 31, 1031-1037. [CrossRef] [PubMed]

103. Wang, Q.; Bai, Z.; Li, X.; Hou, L.; Zhang, B. The evidences of human orphan receptor COUP-TFII inhibiting telomerase activity through decreasing hTERT transcription. Cancer Lett. 2004, 214, 81-90. [CrossRef] [PubMed]

104. Chen, W.; Qin, L.; Wang, S.; Li, M.; Shi, D.; Tian, Y.; Wang, J.; Fu, L.; Li, Z.; Guo, W.; et al. CPSF4 activates telomerase reverse transcriptase and predicts poor prognosis in human lung adenocarcinomas. Mol. Oncol. 2014, 8, 704-716. [CrossRef] [PubMed]

105. Renaud, S.; Loukinov, D.; Abdullaev, Z.; Guilleret, I.; Bosman, F.T.; Lobanenkov, V.; Benhattar, J. Dual role of DNA methylation inside and outside of CTCF-binding regions in the transcriptional regulation of the telomerase hTERT gene. Nucleic Acids Res. 2007, 35, 1245-1256. [CrossRef] [PubMed]

106. Min, N.Y.; Kim, J.H.; Choi, J.H.; Liang, W.; Ko, Y.J.; Rhee, S.; Bang, H.; Ham, S.W.; Park, A.J.; Lee, K.H. Selective death of cancer cells by preferential induction of reactive oxygen species in response to (-)-epigallocatechin-3-gallate. Biochem. Biophys. Res. Commun. 2012, 421, 91-97. [CrossRef] [PubMed]

107. Chen, J.; Yao, Z.X.; Chen, J.S.; Gi, Y.J.; Munoz, N.M.; Kundra, S.; Herlong, H.F.; Jeong, Y.S.; Goltsov, A.; Ohshiro, K.; et al. TGF- $\beta$ / $\beta 2$-spectrin/CTCF-regulated tumor suppression in human stem cell disorder beckwith-wiedemann syndrome. J. Clin. Investig. 2016, 126, 527-542. [CrossRef] [PubMed]

108. Meeran, S.M.; Patel, S.N.; Tollefsbol, T.O. Sulforaphane causes epigenetic repression of hTERT expression in human breast cancer cell lines. PLoS ONE 2010, 5, e11457. [CrossRef] [PubMed]

109. Karam, M.; Thenoz, M.; Capraro, V.; Robin, J.-P.; Pinatel, C.; Lançon, A.; Galia, P.; Sibon, D.; Thomas, X.; Ducastelle-Lepretre, $\mathrm{S}$; ; et al. Chromatin redistribution of the DEK oncoprotein represses $h T E R T$ transcription in leukemias. Neoplasia 2014, 16, 21-30. [CrossRef] [PubMed]

110. Crowe, D.L.; Nguyen, D.C.; Tsang, K.J.; Kyo, S. E2F-1 represses transcription of the human telomerase reverse transcriptase gene. Nucleic Acids Res. 2001, 29, 2789-2794. [CrossRef] [PubMed]

111. Lacerte, A.; Korah, J.; Roy, M.; Yang, X.J.; Lemay, S.; Lebrun, J.J. Transforming growth factor-beta inhibits telomerase through SMAD3 and E2F transcription factors. Cell Signal 2008, 20, 50-59. [CrossRef] [PubMed]

112. Gizard, F.; Nomiyama, T.; Zhao, Y.; Findeisen, H.M.; Heywood, E.B.; Jones, K.L.; Staels, B.; Bruemmer, D. The PPARalpha/p16 ${ }^{\mathrm{INK} 4 \mathrm{a}}$ pathway inhibits vascular smooth muscle cell proliferation by repressing cell cycle-dependent telomerase activation. Circ. Res. 2008, 103, 1155-1163. [CrossRef] [PubMed]

113. Sekaric, P.; Cherry, J.J.; Androphy, E.J. Binding of human papillomavirus type 16 E6 to E6ap is not required for activation of hTERT. J. Virol. 2008, 82, 71-76. [CrossRef] [PubMed]

114. Akutagawa, O.; Nishi, H.; Kyo, S.; Higuma, C.; Inoue, M.; Isaka, K. Early growth response-1 mediates up-regulation of telomerase in placenta. Placenta 2007, 28, 920-927. [CrossRef] [PubMed]

115. Akutagawa, O.; Nishi, H.; Kyo, S.; Terauchi, F.; Yamazawa, K.; Higuma, C.; Inoue, M.; Isaka, K. Early growth response-1 mediates downregulation of telomerase in cervical cancer. Cancer Sci. 2008, 99, 1401-1406. [CrossRef] [PubMed]

116. Grasselli, A.; Nanni, S.; Colussi, C.; Aiello, A.; Benvenuti, V.; Ragone, G.; Moretti, F.; Sacchi, A.; Bacchetti, S.; Gaetano, C.; et al. Estrogen receptor-alpha and endothelial nitric oxide synthase nuclear complex regulates transcription of human telomerase. Circ. Res. 2008, 103, 34-42. [CrossRef] [PubMed]

117. Goueli, B.S.; Janknecht, R. Upregulation of the catalytic telomerase subunit by the transcription factor ER81 and oncogenic HER2/Neu, Ras, or Raf. Mol. Cell. Biol. 2003, 24, 25-35. [CrossRef]

118. Misiti, S.; Nanni, S.; Fontemaggi, G.; Cong, Y.S.; Wen, J.; Hirte, H.W.; Piaggio, G.; Sacchi, A.; Pontecorvi, A.; Bacchetti, S.; et al. Induction of $h T E R T$ expression and telomerase activity by estrogens in human ovary epithelium cells. Mol. Cell. Biol. 2000, 20, 3764-3771. [CrossRef] [PubMed] 
119. Kondoh, K.; Tsuji, N.; Asanuma, K.; Kobayashi, D.; Watanabe, N. Inhibition of estrogen receptor beta-mediated human telomerase reverse transcriptase gene transcription via the suppression of mitogen-activated protein kinase signaling plays an important role in 15-deoxy-delta(12,14)-prostaglandin $\mathrm{J}_{2}$-induced apoptosis in cancer cells. Exp. Cell Res. 2007, 313, 3486-3496. [PubMed]

120. Kasiappan, R.; Sun, Y.; Lungchukiet, P.; Quarni, W.; Zhang, X.; Bai, W. Vitamin d suppresses leptin stimulation of cancer growth through microrna. Cancer Res. 2014, 74, 6194-6204. [CrossRef] [PubMed]

121. Marconett, C.N.; Sundar, S.N.; Tseng, M.; Tin, A.S.; Tran, K.Q.; Mahuron, K.M.; Bjeldanes, L.F.; Firestone, G.L. Indole-3-carbinol downregulation of telomerase gene expression requires the inhibition of estrogen receptor-alpha and Sp1 transcription factor interactions within the hTERT promoter and mediates the g1 cell cycle arrest of human breast cancer cells. Carcinogenesis 2011, 32, 1315-1323. [CrossRef] [PubMed]

122. Wang, Z.; Kyo, S.; Takakura, M.; Tanaka, M.; Yatabe, N.; Maida, Y.; Fujiwara, M.; Hayakawa, J.; Ohmichi, M.; Koike, K.; et al. Progesterone regulates human telomerase reverse transcriptase gene expression via activation of mitogen-activated protein kinase signaling pathway. Cancer Res. 2000, 60, 5376-5381. [PubMed]

123. Hsu, C.P.; Lee, L.W.; Tang, S.C.; Hsin, I.L.; Lin, Y.W.; Ko, J.L. Epidermal growth factor activates telomerase activity by direct binding of ETS-2 to hTERT promoter in lung cancer cells. Tumour Biol. 2015, 36, 5389-5398. [CrossRef] [PubMed]

124. Maida, Y.; Kyo, S.; Kanaya, T.; Wang, Z.; Yatabe, N.; Tanaka, M.; Nakamura, M.; Ohmichi, M.; Gotoh, N.; Murakami, S.; et al. Direct activation of telomerase by EGF through Ets-mediated transactivation of TERT via map kinase signaling pathway. Oncogene 2002, 21, 4071-4079. [CrossRef] [PubMed]

125. Xiao, X.; Athanasiou, M.; Sidorov, I.A.; Horikawa, I.; Cremona, G.; Blair, D.; Barret, J.C.; Dimitrov, D.S. Role of Ets/Id proteins for telomerase regulation in human cancer cells. Exp. Mol. Pathol. 2003, 75, 238-247. [CrossRef]

126. Takahashi, A.; Higashino, F.; Aoyagi, M.; Yoshida, K.; Itoh, M.; Kyo, S.; Ohno, T.; Taira, T.; Ariga, H.; Nakajima, K.; et al. EWS/EST fusions activate telomerase in ewing's tumors. Cancer Res. 2003, 63, 8338-8344. [PubMed]

127. Ogawa, D.; Nomiyama, T.; Nakamachi, T.; Heywood, E.B.; Stone, J.F.; Berger, J.P.; Law, R.E.; Bruemmer, D. Activation of peroxisome proliferator-activated receptor gamma suppresses telomerase activity in vascular smooth muscle cells. Circ. Res. 2006, 98, e50-e59. [CrossRef] [PubMed]

128. Mazumdar, T.; Sandhu, R.; Qadan, M.; DeVecchio, J.; Magloire, V.; Agyeman, A.; Li, B.; Houghton, J.A. Hedgehog signaling regulates telomerase reverse transcriptase in human cancer cells. PLOS ONE 2013, 8, e75253. [CrossRef] [PubMed]

129. Chen, W.; Dong, Q.; Shin, K.H.; Kim, R.H.; Oh, J.E.; Park, N.H.; Kang, M.K. Grainyhead-like 2 enhances the human telomerase reverse transcriptase gene expression by inhibiting DNA methylation at the $5^{\prime}$-CPG island in normal human keratinocytes. J. Biol. Chem. 2010, 285, 40852-40863. [CrossRef]

130. Kang, X.; Chen, W.; Kim, R.H.; Kang, M.K.; Park, N.H. Regulation of the hTERT promoter activity by MSH2, the hnRNPs K and D, and GRHL2 in human oral squamous cell carcinoma cells. Oncogene 2009, 28, 565-574. [CrossRef] [PubMed]

131. Yatabe, N.; Kyo, S.; Maida, Y.; Nishi, H.; Nakamura, M.; Kanaya, T.; Tanaka, M.; Isaka, K.; Ogawa, S.; Inoue, M. HIF-1-mediated activation of telomerase in cervical cancer cells. Oncogene 2004, 23, 3708-3715. [CrossRef] [PubMed]

132. Nishi, H.; Nakada, T.; Kyo, S.; Inoue, M.; Shay, J.W.; Isaka, K. Hypoxia-inducible factor 1 mediates upregulation of telomerase (hTERT). Mol. Cell. Biol. 2004, 24, 6076-6083. [CrossRef] [PubMed]

133. Yang, K.; Zheng, D.; Deng, X.; Bai, L.; Xu, Y.; Cong, Y.S. Lysophosphatidic acid activates telomerase in ovarian cancer cells through hypoxia-inducible factor- $1 \alpha$ and the PI3K pathway. J. Cell. Biochem. 2008, 105, 1194-1201. [CrossRef] [PubMed]

134. Lou, F.; Chen, X.; Jalink, M.; Zhu, Q.; Ge, N.; Zhao, S.; Fang, X.; Fan, Y.; Bjorkholm, M.; Liu, Z.; et al. The opposing effect of hypoxia-inducible factor- $2 \alpha$ on expression of telomerase reverse transcriptase. Mol. Cancer Res. 2007, 5, 793-800. [CrossRef] [PubMed]

135. Kim, R.H.; Kim, R.; Chen, W.; Hu, S.; Shin, K.H.; Park, N.H.; Kang, M.K. Association of HSP90 to the hTERT promoter is necessary for hTERT expression in human oral cancer cells. Carcinogenesis 2008, 29, 2425-2431. [CrossRef] [PubMed] 
136. Hara, T.; Mizuguchi, M.; Fujii, M.; Nakamura, M. Kruppel-like factor 2 represses transcription of the telomerase catalytic subunit human telomerase reverse transcriptase (hTERT) in human t cells. J. Biol. Chem. 2015, 290, 8758-8763. [CrossRef] [PubMed]

137. Wong, C.W.; Hou, P.S.; Tseng, S.F.; Chien, C.L.; Wu, K.J.; Chen, H.F.; Ho, H.N.; Kyo, S.; Teng, S.C. Kruppel-like transcription factor 4 contributes to maintenance of telomerase activity in stem cells. Stem Cells 2010, 28, 1510-1517. [CrossRef] [PubMed]

138. Zhu, Q.; Liu, C.; Ge, Z.; Fang, X.; Zhang, X.; Straat, K.; Bjorkholm, M.; Xu, D. Lysine-specific demethylase 1 (LSD1) is required for the transcriptional repression of the telomerase reverse transcriptase ( $h T E R T)$ gene. PLOS ONE 2008, 3, e1446. [CrossRef] [PubMed]

139. Gunes, C.; Lichtsteiner, S.; Vasserot, A.P.; Englert, C. Expression of the $h T E R T$ gene is regulated at the level of transcriptional initiation and repressed by mad1. Cancer Res. 2000, 60, 2116-2121. [PubMed]

140. Farhana, L.; Dawson, M.I.; Fontana, J.A. Down regulation of miR-202 modulates Mxd1 and Sin3A repressor complexes to induce apoptosis of pancreatic cancer cells. Cancer Biol. Ther. 2015, 16, 115-124. [CrossRef] [PubMed]

141. Xu, M.; Katzenellenbogen, R.A.; Grandori, C.; Galloway, D.A. An unbiased in vivo screen reveals multiple transcription factors that control HPV E6-regulated hTERT in keratinocytes. Virology 2013, 446, 17-24. [CrossRef] [PubMed]

142. Su, J.M.; Lai, X.M.; Lan, K.H.; Li, C.P.; Chao, Y.; Yen, S.H.; Chang, F.Y.; Lee, S.D.; Lee, W.P. X protein of hepatitis $\mathrm{B}$ virus functions as a transcriptional corepressor on the human telomerase promoter. Hepatology 2007, 46, 402-413. [CrossRef] [PubMed]

143. Shi, L.; Li, M.; Su, B. MCPH1/BRIT1 represses transcription of the human telomerase reverse transcriptase gene. Gene 2012, 495, 1-9. [CrossRef] [PubMed]

144. Hashimoto, M.; Kyo, S.; Hua, X.; Tahara, H.; Nakajima, M.; Takakura, M.; Sakaguchi, J.; Maida, Y.; Nakamura, M.; Ikoma, T.; et al. Role of menin in the regulation of telomerase activity in normal and cancer cells. Int. J. Oncol. 2008, 33, 333-340. [PubMed]

145. Borowiak, M.; Kuhlmann, A.S.; Girard, S.; Gazzolo, L.; Mesnard, J.M.; Jalinot, P.; Dodon, M.D. HTLV-1 BZIP factor impedes the menin tumor suppressor and upregulates jund-mediated transcription of the $h T E R T$ gene. Carcinogenesis 2013, 34, 2664-2672. [CrossRef] [PubMed]

146. Fujimoto, K.; Kyo, S.; Takakura, M.; Kanaya, T.; Kitagawa, Y.; Itoh, H.; Takahashi, M.; Inoue, M. Identification and characterization of negative regulatory elements of the human telomerase catalytic subunit $(h T E R T)$ gene promoter: Possible role of MZF-2 in transcriptional repression of hTERT. Nucleic Acids Res. 2000, 28, 2557-2562. [CrossRef] [PubMed]

147. Gizard, F.; Heywood, E.B.; Findeisen, H.M.; Zhao, Y.; Jones, K.L.; Cudejko, C.; Post, G.R.; Staels, B.; Bruemmer, D. Telomerase activation in atherosclerosis and induction of telomerase reverse transcriptase expression by inflammatory stimuli in macrophages. Arterioscler. Thromb. Vasc. Biol. 2011, 31, 245-252. [CrossRef] [PubMed]

148. Aravindan, N.; Veeraraghavan, J.; Madhusoodhanan, R.; Herman, T.S.; Natarajan, M. Curcumin regulates low-linear energy transfer gamma-radiation-induced $\mathrm{NF}_{\kappa} \mathrm{B}$-dependent telomerase activity in human neuroblastoma cells. Int. J. Radiat. Oncol. Biol. Phys. 2011, 79, 1206-1215. [CrossRef] [PubMed]

149. Chung, S.S.; Aroh, C.; Vadgama, J.V. Constitutive activation of STAT3 signaling regulates hTERT and promotes stem cell-like traits in human breast cancer cells. PLoS ONE 2013, 8, e83971. [CrossRef] [PubMed]

150. Bellon, M.; Nicot, C. Central role of PI3K in transcriptional activation of hTERT in HTLV-I-Infected cells. Blood 2008, 112, 2946-2955. [CrossRef] [PubMed]

151. Kawagoe, J.; Ohmichi, M.; Takahashi, T.; Ohshima, C.; Mabuchi, S.; Takahashi, K.; Igarashi, H.; Mori-Abe, A.; Saitoh, M.; Du, B.; et al. Raloxifene inhibits estrogen-induced up-regulation of telomerase activity in a human breast cancer cell line. J. Biol. Chem. 2003, 278, 43363-43372. [CrossRef] [PubMed]

152. Natarajan, M.; Mohan, S.; Konopinski, R.; Otto, R.A.; Herman, T.S. Induced telomerase activity in primary aortic endothelial cells by low-let gamma-radiation is mediated through NF-kb activation. Br. J. Radiol. 2008, 81, 711-720. [CrossRef] [PubMed]

153. Aravindan, N.; Aravindan, S.; Herman, T.S.; Natarajan, M. EGFR tyrosine kinase inhibitor pelitinib regulates radiation-induced p65-dependent telomerase activation in squamous cell carcinoma. Radiat. Res. 2013, 179, 304-312. [CrossRef] [PubMed] 
154. Chebel, A.; Rouault, J.P.; Urbanowicz, I.; Baseggio, L.; Chien, W.W.; Salles, G.; Ffrench, M. Transcriptional activation of $h T E R T$, the human telomerase reverse transcriptase, by nuclear factor of activated T cells. J. Biol. Chem. 2009, 284, 35725-35734. [CrossRef] [PubMed]

155. Galloway, D.A.; Gewin, L.C.; Myers, H.; Luo, W.; Grandori, C.; Katzenellenbogen, R.A.; McDougall, J.K. Regulation of telomerase by human papillomaviruses. Cold Spring Harb. Symp. Quant. Biol. 2005, 70, $209-215$. [CrossRef] [PubMed]

156. Bougel, S.; Renaud, S.; Braunschweig, R.; Loukinov, D.; Morse, H.C., III; Bosman, F.T.; Lobanenkov, V.; Benhattar, J. PAX5 activates the transcription of the human telomerase reverse transcriptase gene in B cells. J. Pathol. 2010, 220, 87-96. [CrossRef] [PubMed]

157. Chen, Y.J.; Campbell, H.G.; Wiles, A.K.; Eccles, M.R.; Reddel, R.R.; Braithwaite, A.W.; Royds, J.A. PAX8 regulates telomerase reverse transcriptase and telomerase RNA component in glioma. Cancer Res. 2008, 68, 5724-5732. [CrossRef] [PubMed]

158. Qi, D.L.; Ohhira, T.; Fujisaki, C.; Inoue, T.; Ohta, T.; Osaki, M.; Ohshiro, E.; Seko, T.; Aoki, S.; Oshimura, M.; et al. Identification of PITX1 as a TERT suppressor gene located on human chromosome 5. Mol. Cell. Biol. 2011, 31, 1624-1636. [CrossRef] [PubMed]

159. Ohira, T.; Naohiro, S.; Nakayama, Y.; Osaki, M.; Okada, F.; Oshimura, M.; Kugoh, H. miR-19b regulates hTERT mRNA expression through targeting PITX1 mRNA in melanoma cells. Sci. Rep. 2015. [CrossRef] [PubMed]

160. Luan, F.; Liu, H.; Gao, L.; Liu, J.; Sun, Z.; Ju, Y.; Hou, N.; Guo, C.; Liang, X.; Zhang, L.; et al. Hepatitis B virus protein preS2 potentially promotes HCC development via its transcriptional activation of hTERT. Gut 2009, 58, 1528-1537. [CrossRef] [PubMed]

161. Li, W.; Zeng, J.; Li, Q.; Zhao, L.; Liu, T.; Bjorkholm, M.; Jia, J.; Xu, D. Reptin is required for the transcription of telomerase reverse transcriptase and over-expressed in gastric cancer. Mol. Cancer 2010. [CrossRef] [PubMed]

162. Chen, W.; Lu, J.; Qin, Y.; Wang, J.; Tian, Y.; Shi, D.; Wang, S.; Xiao, Y.; Dai, M.; Liu, L.; et al. Ret finger protein-like 3 promotes tumor cell growth by activating telomerase reverse transcriptase expression in human lung cancer cells. Oncotarget 2014, 5, 11909-11923. [CrossRef] [PubMed]

163. Qin, Y.; Chen, W.; Xiao, Y.; Yu, W.; Cai, X.; Dai, M.; Xu, T.; Huang, W.; Guo, W.; Deng, W.; et al. RFPL3 and CBP synergistically upregulate hTERT activity and promote lung cancer growth. Oncotarget 2015, 6, 27130-27145. [CrossRef] [PubMed]

164. Guo, W.; Lu, J.; Dai, M.; Wu, T.; Yu, Z.; Wang, J.; Chen, W.; Shi, D.; Yu, W.; Xiao, Y.; et al. Transcriptional coactivator cbp upregulates hTERT expression and tumor growth and predicts poor prognosis in human lung cancers. Oncotarget 2014, 5, 9349-9361. [CrossRef] [PubMed]

165. Knight, J.S.; Cotter, M.A., II; Robertson, E.S. The latency-associated nuclear antigen of kaposi's sarcoma-associated herpesvirus transactivates the telomerase reverse transcriptase promoter. J. Biol. Chem. 2001, 276, 22971-22978. [CrossRef] [PubMed]

166. Verma, S.C.; Borah, S.; Robertson, E.S. Latency-associated nuclear antigen of kaposi's sarcoma-associated herpesvirus up-regulates transcription of human telomerase reverse transcriptase promoter through interaction with transcription factor Sp1. J. Virol. 2004, 78, 10348-10359. [CrossRef] [PubMed]

167. Chau, M.N.; El Touny, L.H.; Jagadeesh, S.; Banerjee, P.P. Physiologically achievable concentrations of genistein enhance telomerase activity in prostate cancer cells via the activation of STAT3. Carcinogenesis 2007, 28, 2282-2290. [CrossRef] [PubMed]

168. Liu, L.; Ishihara, K.; Ichimura, T.; Fujita, N.; Hino, S.; Tomita, S.; Watanabe, S.; Saitoh, N.; Ito, T.; Nakao, M. MCAF1/AM is involved in Sp1-mediated maintenance of cancer-associated telomerase activity. J. Biol. Chem. 2009, 284, 5165-5174. [CrossRef] [PubMed]

169. Liu, H.; Shi, W.; Luan, F.; Xu, S.; Yang, F.; Sun, W.; Liu, J.; Ma, C. Hepatitis B virus X protein upregulates transcriptional activation of human telomerase reverse transcriptase. Virus Genes 2010, 40, 174-182. [CrossRef] [PubMed]

170. Li, A.Y.; Lin, H.H.; Kuo, C.Y.; Shih, H.M.; Wang, C.C.; Yen, Y.; Ann, D.K. High-mobility group a2 protein modulates hTERT transcription to promote tumorigenesis. Mol. Cell. Biol. 2011, 31, 2605-2617. [CrossRef] [PubMed] 
171. Xu, D.; Wang, Q.; Gruber, A.; Bjorkholm, M.; Chen, Z.; Zaid, A.; Selivanova, G.; Peterson, C.; Wiman, K.G.; Pisa, P. Downregulation of telomerase reverse transcriptase mrna expression by wild type p53 in human tumor cells. Oncogene 2000, 19, 5123-5133. [CrossRef] [PubMed]

172. Beitzinger, M.; Oswald, C.; Beinoraviciute-Kellner, R.; Stiewe, T. Regulation of telomerase activity by the p53 family member p73. Oncogene 2006, 25, 813-826. [CrossRef] [PubMed]

173. Racek, T.; Mise, N.; Li, Z.; Stoll, A.; Putzer, B.M. C-terminal p73 isoforms repress transcriptional activity of the human telomerase reverse transcriptase (hTERT) promoter. J. Biol. Chem. 2005, 280, 40402-40405. [CrossRef] [PubMed]

174. Wooten, L.G.; Ogretmen, B. Sp1/Sp3-dependent regulation of human telomerase reverse transcriptase promoter activity by the bioactive sphingolipid ceramide. J. Biol. Chem. 2005, 280, 28867-28876. [CrossRef] [PubMed]

175. Lee, D.; Kim, H.Z.; Jeong, K.W.; Shim, Y.S.; Horikawa, I.; Barrett, J.C.; Choe, J. Human papillomavirus E2 down-regulates the human telomerase reverse transcriptase promoter. J. Biol. Chem. 2002, 277, 27748-27756. [CrossRef] [PubMed]

176. Won, J.; Yim, J.; Kim, T.K. Opposing regulatory roles of E2F in human telomerase reverse transcriptase (hTERT) gene expression in human tumor and normal somatic cells. FASEB J. 2002, 16, 1943-1945. [CrossRef] [PubMed]

177. Saito, M.; Nakagawa, K.; Hamada, K.; Hirose, S.; Harada, H.; Kohno, S.; Nagato, S.; Ohnishi, T. Introduction of p16INK4a inhibits telomerase activity through transcriptional suppression of human telomerase reverse transcriptase expression in human gliomas. Int. J. Oncol. 2004, 24, 1213-1220. [CrossRef] [PubMed]

178. Lin, P.C.; Lin, S.Z.; Chen, Y.L.; Chang, J.S.; Ho, L.I.; Liu, P.Y.; Chang, L.F.; Harn, Y.C.; Chen, S.P.; Sun, L.Y.; et al. Butylidenephthalide suppresses human telomerase reverse transcriptase (TERT) in human glioblastomas. Ann. Surg. Oncol. 2011, 18, 3514-3527. [CrossRef] [PubMed]

179. Shapira, S.; Granot, G.; Mor-Tzuntz, R.; Raanani, P.; Uziel, O.; Lahav, M.; Shpilberg, O. Second-generation tyrosine kinase inhibitors reduce telomerase activity in K562 cells. Cancer Lett. 2012, 323, 223-231. [CrossRef] [PubMed]

180. Deeb, D.; Brigolin, C.; Gao, X.; Liu, Y.; Pindolia, K.R.; Gautam, S.C. Induction of apoptosis in pancreatic cancer cells by CDDO-Me involves repression of telomerase through epigenetic pathways. J. Carcinog. Mutagen. 2014. [CrossRef] [PubMed]

181. Zhang, D.; Sun, X.; Liu, J.; Xie, X.; Cui, W.; Zhu, Y. Homocysteine accelerates senescence of endothelial cells via DNA hypomethylation of human telomerase reverse transcriptase. Arterioscler. Thromb. Vasc. Biol. 2015, 35, 71-78. [CrossRef] [PubMed]

182. Long, C.; Wang, J.; Guo, W.; Wang, H.; Wang, C.; Liu, Y.; Sun, X. Triptolide inhibits transcription of hTERT through down-regulation of transcription factor specificity protein 1 in primary effusion lymphoma cells. Biochem. Biophys. Res. Commun. 2016, 469, 87-93. [CrossRef] [PubMed]

183. Won, J.; Yim, J.; Kim, T.K. Sp1 and Sp3 recruit histone deacetylase to repress transcription of human telomerase reverse transcriptase (hTERT) promoter in normal human somatic cells. J. Biol. Chem. 2002, 277, 38230-38238. [CrossRef] [PubMed]

184. Glasspool, R.M.; Burns, S.; Hoare, S.F.; Svensson, C.; Keith, W.N. The hTERT and $h T E R C$ telomerase gene promoters are activated by the second exon of the adenoviral protein, E1 A, identifying the transcriptional corepressor CtBP as a potential rearessor of both genes. Neoplasia 2005, 7, 614-622. [CrossRef] [PubMed]

185. Fujiki, T.; Miura, T.; Maura, M.; Shiraishi, H.; Nishimura, S.; Imada, Y.; Uehara, N.; Tashiro, K.; Shirahata, S.; Katakura, Y. TAK1 represses transcription of the human telomerase reverse transcriptase gene. Oncogene 2007, 26, 5258-5266. [CrossRef] [PubMed]

186. Wooten-Blanks, L.G.; Song, P.; Senkal, C.E.; Ogretmen, B. Mechanisms of ceramide-mediated repression of the human telomerase reverse transcriptase promoter via deacetylation of Sp3 by histone deacetylase 1. FASEB J. 2007, 21, 3386-3397. [CrossRef] [PubMed]

187. Chen, R.; Zhu, J.; Dong, Y.; He, C.; Hu, X. Suppressor of Ty homolog-5, a novel tumor-specific human telomerase reverse transcriptase promoter-binding protein and activator in colon cancer cells. Oncotarget 2015, 6, 32841-32855. [PubMed]

188. Ren, H.; Zhao, T.; Wang, X.; Gao, C.; Wang, J.; Yu, M.; Hao, J. Leptin upregulates telomerase activity and transcription of human telomerase reverse transcriptase in MCF-7 breast cancer cells. Biochem. Biophys. Res. Commun. 2010, 394, 59-63. [CrossRef] [PubMed] 
189. Nakatake, M.; Kakiuchi, Y.; Sasaki, N.; Murakami-Murofushi, K.; Yamada, O. STAT3 and PKC differentially regulate telomerase activity during megakaryocytic differentiation of K562 cells. Cell Cycle 2007, 6, 1496-1501. [CrossRef] [PubMed]

190. Konnikova, L.; Simeone, M.C.; Kruger, M.M.; Kotecki, M.; Cochran, B.H. Signal transducer and activator of transcription 3 (STAT3) regulates human telomerase reverse transcriptase (hTERT) expression in human cancer and primary cells. Cancer Res. 2005, 65, 6516-6520. [CrossRef] [PubMed]

191. Wang, Y.Y.; Sun, G.; Luo, H.; Wang, X.F.; Lan, F.M.; Yue, X.; Fu, L.S.; Pu, P.Y.; Kang, C.S.; Liu, N.; et al. MiR-21 modulates hTERT through a STAT3-dependent manner on glioblastoma cell growth. CNS Neurosci. Ther. 2012, 18, 722-728. [CrossRef] [PubMed]

192. Guo, N.; Cheng, D.; Li, Z.H.; Zhou, Q.B.; Zhou, J.J.; Lin, Q.; Zeng, B.; Liao, Q.; Chen, R.F. Transfection of HCVc improves hTERT expression through STAT3 pathway by epigenetic regulation in Huh7 cells. J. Cell. Biochem. 2012, 113, 3419-3426. [CrossRef] [PubMed]

193. Yamada, O.; Ozaki, K.; Akiyama, M.; Kawauchi, K. JAK-STAT and JAK-PI3K-mTORC1 pathways regulate telomerase transcriptionally and posttranslationally in atl cells. Mol. Cancer Ther. 2012, 11, 1112-1121. [CrossRef] [PubMed]

194. Yamada, O.; Ozaki, K.; Furukawa, T.; Machida, M.; Wang, Y.H.; Motoji, T.; Mitsuishi, T.; Akiyama, M.; Yamada, H.; Kawauchi, K.; et al. Activation of STAT5 confers imatinib resistance on leukemic cells through the transcription of TERT and mdr1. Cell Signal 2011, 23, 1119-1127. [CrossRef] [PubMed]

195. Akiyama, M.; Kawano, T.; Mikami-Terao, Y.; Agawa-Ohta, M.; Yamada, O.; Ida, H.; Yamada, H. Erythropoietin activates telomerase through transcriptional and posttranscriptional regulation in human erythroleukemic JAS-REN-A cells. Leuk. Res. 2011, 35, 416-418. [CrossRef] [PubMed]

196. Prade-Houdellier, N.; Frebet, E.; Demur, C.; Gautier, E.F.; Delhommeau, F.; Bennaceur-Griscelli, A.L.; Gaudin, C.; Martinel, V.; Laurent, G.; Mansat-De Mas, V.; et al. Human telomerase is regulated by erythropoietin and transforming growth factor- $\beta$ in human erythroid progenitor cells. Leukemia 2007, 21, 2304-2310. [CrossRef] [PubMed]

197. Terme, J.M.; Mocquet, V.; Kuhlmann, A.S.; Zane, L.; Mortreux, F.; Wattel, E.; Duc Dodon, M.; Jalinot, P. Inhibition of the hTERT promoter by the proto-oncogenic protein TAL1. Leukemia 2009, 23, 2081-2089. [CrossRef] [PubMed]

198. Tang, Z.; Zhao, Y.; Mei, F.; Yang, S.; Li, X.; Lv, J.; Hou, L.; Zhang, B. Molecular cloning and characterization of a human gene involved in transcriptional regulation of hTERT. Biochem. Biophys. Res. Commun. 2004, 324, 1324-1332. [CrossRef] [PubMed]

199. Hsu, C.C.; Chen, C.H.; Hsu, T.I.; Hung, J.J.; Ko, J.L.; Zhang, B.; Lee, Y.C.; Chen, H.K.; Chang, W.C.; Lin, D.Y. The 58-kDa microspherule protein (MSP58) represses human telomerase reverse transcriptase ( $h T E R T$ ) gene expression and cell proliferation by interacting with telomerase transcriptional element-interacting factor (TEIF). Biochim. Biophys. Acta 2014, 1843, 565-579. [CrossRef] [PubMed]

200. Goueli, B.S.; Janknecht, R. Regulation of telomerase reverse transcriptase gene activity by upstream stimulatory factor. Oncogene 2003, 22, 8042-8047. [CrossRef] [PubMed]

201. Yago, M.; Ohki, R.; Hatakeyama, S.; Fujita, T.; Ishikawa, F. Variant forms of upstream stimulatory factors (USFs) control the promoter activity of $h T E R T$, the human gene encoding the catalytic subunit of telomerase. FEBS Lett. 2002, 520, 40-46. [CrossRef]

202. Chang, J.T.; Yang, H.T.; Wang, T.C.; Cheng, A.J. Upstream stimulatory factor (USF) as a transcriptional suppressor of human telomerase reverse transcriptase (hTERT) in oral cancer cells. Mol. Carcinog. 2005, 44, 183-192. [CrossRef] [PubMed]

203. Ikeda, N.; Uemura, H.; Ishiguro, H.; Hori, M.; Hosaka, M.; Kyo, S.; Miyamoto, K.; Takeda, E.; Kubota, Y. Combination treatment with 1 $\alpha, 25$-dihydroxyvitamin D3 and 9-Cis-Retinoic acid directly inhibits human telomerase reverse transcriptase transcription in prostate cancer cells. Mol. Cancer Ther. 2003, 2, 739-746. [PubMed]

204. Oh, S.; Song, Y.; Yim, J.; Kim, T.K. The wilms' tumor 1 tumor suppressor gene represses transcription of the human telomerase reverse transcriptase gene. J. Biol. Chem. 1999, 274, 37473-37478. [CrossRef] [PubMed]

205. Veldman, T.; Horikawa, I.; Barrett, J.C.; Schlegel, R. Transcriptional activation of the telomerase hTERT gene by human papillomavirus type 16 E6 oncoprotein. J. Virol. 2001, 75, 4467-4472. [CrossRef] [PubMed]

206. Kanzawa, T.; Komata, T.; Kyo, S.; Germano, I.M.; Kondo, Y.; Kondo, S. Down-regulation of telomerase activity in malignant glioma cells by p27KIP1. Int. J. Oncol. 2003, 23, 1703-1708. [CrossRef] [PubMed] 
207. Yoon, J.H.; Seo, H.S.; Choi, W.S.; Kim, O.; Nam, S.W.; Lee, J.Y.; Park, W.S. Gastrokine 1 induces senescence and apoptosis through regulating telomere length in gastric cancer. Oncotarget 2014, 5, 11695-11708. [CrossRef] [PubMed]

208. Kirkpatrick, K.L.; Newbold, R.F.; Mokbel, K. There is no correlation between c-Myc mRNA expression and telomerase activity in human breast cancer. Int. Semin. Surg. Oncol. 2004. [CrossRef] [PubMed]

209. Elkak, A.E.; Meligonis, G.; Salhab, M.; Mitchell, B.; Blake, J.R.; Newbold, R.F.; Mokbel, K. hTERT protein expression is independent of clinicopathological parameters and c-Myc protein expression in human breast cancer. J. Carcinog. 2005. [CrossRef]

210. Nakagawa, M.; Koyanagi, M.; Tanabe, K.; Takahashi, K.; Ichisaka, T.; Aoi, T.; Okita, K.; Mochiduki, Y.; Takizawa, N.; Yamanaka, S. Generation of induced pluripotent stem cells without Myc from mouse and human fibroblasts. Nat. Biotechnol. 2008, 26, 101-106. [CrossRef] [PubMed]

211. Ghosh, A.; Saginc, G.; Leow, S.C.; Khattar, E.; Shin, E.M.; Yan, T.D.; Wong, M.; Zhang, Z.; Li, G.; Sung, W.K.; et al. Telomerase directly regulates NF-kB-dependent transcription. Nat. Cell Biol. 2012, 14, 1270-1281. [CrossRef] [PubMed]

212. Ding, D.; Xi, P.; Zhou, J.; Wang, M.; Cong, Y.S. Human telomerase reverse transcriptase regulates $\mathrm{mmp}$ expression independently of telomerase activity via NF-kB-dependent transcription. FASEB J. 2013, 27, 4375-4383. [CrossRef] [PubMed]

213. Li, Y.; Zhou, Q.L.; Sun, W.; Chandrasekharan, P.; Cheng, H.S.; Ying, Z.; Lakshmanan, M.; Raju, A.; Tenen, D.G.; Cheng, S.Y.; et al. Non-canonical NF-кB signalling and ETS1/2 cooperatively drive C250T mutant TERT promoter activation. Nat. Cell Biol. 2015, 17, 1327-1338. [CrossRef] [PubMed]

214. Wang, X.H.; Liu, B.R.; Qu, B.; Xing, H.; Gao, S.L.; Yin, J.M.; Wang, X.F.; Cheng, Y.Q. Silencing STAT3 may inhibit cell growth through regulating signaling pathway, telomerase, cell cycle, apoptosis and angiogenesis in hepatocellular carcinoma: Potential uses for gene therapy. Neoplasma 2011, 58, 158-171. [CrossRef] [PubMed]

215. Boggess, J.F.; Zhou, C.; Bae-Jump, V.L.; Gehrig, P.A.; Whang, Y.E. Estrogen-receptor-dependent regulation of telomerase activity in human endometrial cancer cell lines. Gynecol. Oncol. 2006, 103, 417-424. [CrossRef] [PubMed]

216. Briatore, F.; Barrera, G.; Pizzimenti, S.; Toaldo, C.; Casa, C.D.; Laurora, S.; Pettazzoni, P.; Dianzani, M.U.; Ferrero, D. Increase of telomerase activity and hTERT expression in myelodysplastic syndromes. Cancer Biol. Ther. 2009, 8, 883-889. [CrossRef] [PubMed]

217. Meeran, S.M.; Patel, S.N.; Chan, T.H.; Tollefsbol, T.O. A novel prodrug of epigallocatechin-3-gallate: Differential epigenetic hTERT repression in human breast cancer cells. Cancer Prev. Res. 2011, 4, 1243-1254. [CrossRef] [PubMed]

218. Chen, H.J.; Yu, R.A.; He, L.F.; An, S.J.; Wu, Z.G.; Yang, K.D.; Chen, X.M. Inhibitory effects of selenium on telomerase activity and hTERT expression in cadmium-transformed 16HBE cells. Biomed. Environ. Sci. 2007, 20, 307-312. [PubMed]

219. Cheng, D.; Zhao, Y.; Wang, S.; Jia, W.; Kang, J.; Zhu, J. Human telomerase reverse transcriptase ( $h T E R T)$ transcription requires $\mathrm{Sp} 1 / \mathrm{Sp} 3$ binding to the promoter and a permissive chromatin environment. J. Biol. Chem. 2015, 290, 30193-30203. [CrossRef] [PubMed]

220. Pang, J.X.; Chen, X.Y.; Wu, S.G. Regulation of telomerase activity in Jurkat T cells by transcription factors Sp1 and Sp3. Di Yi Jun Yi Da Xue Xue Bao 2002, 22, 481-485. [PubMed]

221. Eldholm, V.; Haugen, A.; Zienolddiny, S. Ctcf mediates the TERT enhancer-promoter interactions in lung cancer cells: Identification of a novel enhancer region involved in the regulation of TERT gene. Int. J. Cancer 2014, 134, 2305-2313. [CrossRef] [PubMed]

222. Jiang, F.; Bao, J.; Li, P.; Nicosia, S.V.; Bai, W. Induction of ovarian cancer cell apoptosis by 1,25-dihydroxyvitamin D3 through the down-regulation of telomerase. J. Biol. Chem. 2004, 279, 53213-53221. [CrossRef] [PubMed]

223. Kasiappan, R.; Shen, Z.; Tse, A.K.; Jinwal, U.; Tang, J.; Lungchukiet, P.; Sun, Y.; Kruk, P.; Nicosia, S.V.; Zhang, X.; et al. 1,25-Dihydroxyvitamin $\mathrm{d} 3$ suppresses telomerase expression and human cancer growth through microrna-498. J. Biol. Chem. 2012, 287, 41297-41309. [CrossRef] [PubMed]

224. Kanaya, T.; Kyo, S.; Hamada, K.; Takakura, M.; Kitagawa, Y.; Harada, H.; Inoue, M. Adenoviral expression of p53 represses telomerase activity through down-regulation of human telomerase reverse transcriptase transcription. Clin. Cancer Res. 2000, 6, 1239-1247. [PubMed] 
225. Saito, T.; Akaike, K.; Kurisaki-Arakawa, A.; Toda-Ishii, M.; Mukaihara, K.; Suehara, Y.; Takagi, T.; Kaneko, K.; Yao, T. Promoter mutations are rare in bone and soft tissue sarcomas of japanese patients. Mol. Clin. Oncol. 2016, 4, 61-64. [CrossRef] [PubMed]

226. Hou, M.; Wang, X.; Popov, N.; Zhang, A.; Zhao, X.; Zhou, R.; Zetterberg, A.; Bjorkholm, M.; Henriksson, M.; Gruber, A.; et al. The histone deacetylase inhibitor trichostatin a derepresses the telomerase reverse transcriptase (hTERT) gene in human cells. Exp. Cell Res. 2002, 274, 25-34. [CrossRef] [PubMed]

227. Takakura, M.; Kyo, S.; Sowa, Y.; Wang, Z.; Yatabe, N.; Maida, Y.; Tanaka, M.; Inoue, M. Telomerase activation by histone deacetylase inhibitor in normal cells. Nucleic Acids Res. 2001, 29, 3006-3011. [CrossRef] [PubMed]

228. Varshney, A.; Ramakrishnan, S.K.; Sharma, A.; Santosh, B.; Bala, J.; Yadava, P.K.; Jaiswal, R.K. Global expression profile of telomerase-associated genes in HeLa cells. Gene 2014, 547, 211-217. [CrossRef] [PubMed]

229. Atkinson, S.P.; Hoare, S.F.; Glasspool, R.M.; Keith, W.N. Lack of telomerase gene expression in alternative lengthening of telomere cells is associated with chromatin remodeling of the $h T R$ and $h T E R T$ gene promoters. Cancer Res. 2005, 65, 7585-7590. [PubMed]

230. Wang, Y.; Chen, T.; Yan, H.; Qi, H.; Deng, C.; Ye, T.; Zhou, S.; Li, F.R. Role of histone deacetylase inhibitors in the aging of human umbilical cord mesenchymal stem cells. J. Cell. Biochem. 2013, 114, 2231-2239. [CrossRef] [PubMed]

231. Haigis, M.C.; Guarente, L.P. Mammalian sirtuins-Emerging roles in physiology, aging, and calorie restriction. Genes Dev. 2006, 20, 2913-2921. [CrossRef] [PubMed]

232. Chen, H.C.; Jeng, Y.M.; Yuan, R.H.; Hsu, H.C.; Chen, Y.L. SIRT1 promotes tumorigenesis and resistance to chemotherapy in hepatocellular carcinoma and its expression predicts poor prognosis. Ann. Surg. Oncol. 2012, 19, 2011-2019. [CrossRef] [PubMed]

233. Mao, B.; Zhao, G.; Lv, X.; Chen, H.Z.; Xue, Z.; Yang, B.; Liu, D.P.; Liang, C.C. SIRT1 deacetylates c-Myc and promotes c-Myc /max association. Int. J. Biochem. Cell Biol. 2011, 43, 1573-1581. [CrossRef] [PubMed]

234. Chen, J.; Zhang, B.; Wong, N.; Lo, A.W.; To, K.F.; Chan, A.W.; Ng, M.H.; Ho, C.Y.; Cheng, S.H.; Lai, P.B.; et al. Sirtuin 1 is upregulated in a subset of hepatocellular carcinomas where it is essential for telomere maintenance and tumor cell growth. Cancer Res. 2011, 71, 4138-4149. [CrossRef] [PubMed]

235. Zhang, B.; Chen, J.; Cheng, A.S.; Ko, B.C. Depletion of sirtuin 1 (SIRT1) leads to epigenetic modifications of telomerase (TERT) gene in hepatocellular carcinoma cells. PLoS ONE 2014, 9, e84931. [CrossRef] [PubMed]

236. Moore, L.D.; Le, T.; Fan, G. DNA methylation and its basic function. Neuropsychopharmacology 2013, 38, 23-38. [CrossRef] [PubMed]

237. Selker, E.U. Gene silencing: Repeats that count. Cell 1999, 97, 157-160. [CrossRef]

238. Devereux, T.R.; Horikawa, I.; Anna, C.H.; Annab, L.A.; Afshari, C.A.; Barrett, J.C. DNA methylation analysis of the promoter region of the human telomerase reverse transcriptase (hTERT) gene. Cancer Res. 1999, 59, 6087-6090. [PubMed]

239. Iliopoulos, D.; Satra, M.; Drakaki, A.; Poultsides, G.A.; Tsezou, A. Epigenetic regulation of $h T E R T$ promoter in hepatocellular carcinomas. Int. J. Oncol. 2009, 34, 391-399. [PubMed]

240. Zinn, R.L.; Pruitt, K.; Eguchi, S.; Baylin, S.B.; Herman, J.G. hTERT is expressed in cancer cell lines despite promoter DNA methylation by preservation of unmethylated DNA and active chromatin around the transcription start site. Cancer Res. 2007, 67, 194-201. [CrossRef] [PubMed]

241. Guilleret, I.; Benhattar, J. Demethylation of the human telomerase catalytic subunit $(h T E R T)$ gene promoter reduced hTERT expression and telomerase activity and shortened telomeres. Exp. Cell Res. 2003, 289, 326-334. [CrossRef]

242. Pettigrew, K.A.; Armstrong, R.N.; Colyer, H.A.; Zhang, S.D.; Rea, I.M.; Jones, R.E.; Baird, D.M.; Mills, K.I. Differential TERT promoter methylation and response to 5-Aza-2'-deoxycytidine in acute myeloid leukemia cell lines: TERT expression, telomerase activity, telomere length, and cell death. Genes Chromosomes Cancer 2012, 51, 768-780. [CrossRef] [PubMed]

243. Dessain, S.K.; Yu, H.; Reddel, R.R.; Beijersbergen, R.L.; Weinberg, R.A. Methylation of the human telomerase gene cpg island. Cancer Res. 2000, 60, 537-541. [PubMed]

244. Guilleret, I.; Yan, P.; Grange, F.; Braunschweig, R.; Bosman, F.T.; Benhattar, J. Hypermethylation of the human telomerase catalytic subunit (hTERT) gene correlates with telomerase activity. Int. J. Cancer 2002, 101, 335-341. [CrossRef] [PubMed] 
245. Castelo-Branco, P.; Choufani, S.; Mack, S.; Gallagher, D.; Zhang, C.; Lipman, T.; Zhukova, N.; Walker, E.J.; Martin, D.; Merino, D.; et al. Methylation of the TERT promoter and risk stratification of childhood brain tumours: An integrative genomic and molecular study. Lancet. Oncol. 2013, 14, 534-542. [CrossRef]

246. Peifer, M.; Hertwig, F.; Roels, F.; Dreidax, D.; Gartlgruber, M.; Menon, R.; Kramer, A.; Roncaioli, J.L.; Sand, F.; Heuckmann, J.M.; et al. Telomerase activation by genomic rearrangements in high-risk neuroblastoma. Nature 2015, 526, 700-704. [CrossRef] [PubMed]

247. Stern, J.L.; Theodorescu, D.; Vogelstein, B.; Papadopoulos, N.; Cech, T.R. Mutation of the TERT promoter, switch to active chromatin, and monoallelic TERT expression in multiple cancers. Genes Dev. 2015, 29, 2219-2224. [CrossRef] [PubMed]

248. Ojesina, A.I.; Lichtenstein, L.; Freeman, S.S.; Pedamallu, C.S.; Imaz-Rosshandler, I.; Pugh, T.J.; Cherniack, A.D.; Ambrogio, L.; Cibulskis, K.; Bertelsen, B.; et al. Landscape of genomic alterations in cervical carcinomas. Nature 2014, 506, 371-375. [CrossRef] [PubMed]

249. Kandoth, C.; McLellan, M.D.; Vandin, F.; Ye, K.; Niu, B.; Lu, C.; Xie, M.; Zhang, Q.; McMichael, J.F.; Wyczalkowski, M.A.; et al. Mutational landscape and significance across 12 major cancer types. Nature 2013, 502, 333-339. [CrossRef] [PubMed]

250. Weinhold, N.; Jacobsen, A.; Schultz, N.; Sander, C.; Lee, W. Genome-wide analysis of noncoding regulatory mutations in cancer. Nat. Genet. 2014, 46, 1160-1165. [CrossRef] [PubMed]

251. Huang, F.W.; Hodis, E.; Xu, M.J.; Kryukov, G.V.; Chin, L.; Garraway, L.A. Highly recurrent TERT promoter mutations in human melanoma. Science 2013, 339, 957-959. [CrossRef] [PubMed]

252. Horn, S.; Figl, A.; Rachakonda, P.S.; Fischer, C.; Sucker, A.; Gast, A.; Kadel, S.; Moll, I.; Nagore, E.; Hemminki, K.; et al. Tert promoter mutations in familial and sporadic melanoma. Science 2013, 339, 959-961. [CrossRef] [PubMed]

253. Killela, P.J.; Reitman, Z.J.; Jiao, Y.; Bettegowda, C.; Agrawal, N.; Diaz, L.A., Jr.; Friedman, A.H.; Friedman, H.; Gallia, G.L.; Giovanella, B.C.; et al. TERT promoter mutations occur frequently in gliomas and a subset of tumors derived from cells with low rates of self-renewal. Proc. Natl. Acad. Sci. USA 2013, 110, 6021-6026. [CrossRef] [PubMed]

254. Quaas, A.; Oldopp, T.; Tharun, L.; Klingenfeld, C.; Krech, T.; Sauter, G.; Grob, T.J. Frequency of TERT promoter mutations in primary tumors of the liver. Virchows Arch. 2014, 465, 673-677. [CrossRef] [PubMed]

255. Kinde, I.; Munari, E.; Faraj, S.F.; Hruban, R.H.; Schoenberg, M.; Bivalacqua, T.; Allaf, M.; Springer, S.; Wang, Y.; Diaz, L.A., Jr.; et al. TERT promoter mutations occur early in urothelial neoplasia and are biomarkers of early disease and disease recurrence in urine. Cancer Res. 2013, 73, 7162-7167. [CrossRef] [PubMed]

256. Griewank, K.G.; Schilling, B.; Murali, R.; Bielefeld, N.; Schwamborn, M.; Sucker, A.; Zimmer, L.; Hillen, U.; Schaller, J.; Brenn, T.; et al. TERT promoter mutations are frequent in atypical fibroxanthomas and pleomorphic dermal sarcomas. Mod. Pathol. 2014, 27, 502-508. [CrossRef] [PubMed]

257. Adeberg, S.; Bernhardt, D.; Harrabi, S.B.; Diehl, C.; Koelsche, C.; Rieken, S.; Unterberg, A.; von Deimling, A.; Debus, J. Radiotherapy plus concomitant temozolomide in primary gliosarcoma. J. Neurooncol. 2016, 128, 341-348. [CrossRef] [PubMed]

258. Oh, J.E.; Ohta, T.; Nonoguchi, N.; Satomi, K.; Capper, D.; Pierscianek, D.; Sure, U.; Vital, A.; Paulus, W.; Mittelbronn, M.; et al. Genetic alterations in gliosarcoma and giant cell glioblastoma. Brain Pathol. 2015. [CrossRef] [PubMed]

259. Koelsche, C.; Sahm, F.; Capper, D.; Reuss, D.; Sturm, D.; Jones, D.T.; Kool, M.; Northcott, P.A.; Wiestler, B.; Bohmer, K.; et al. Distribution of TERT promoter mutations in pediatric and adult tumors of the nervous system. Acta Neuropathol. 2013, 126, 907-915. [CrossRef] [PubMed]

260. Huang, D.S.; Wang, Z.; He, X.J.; Diplas, B.H.; Yang, R.; Killela, P.J.; Meng, Q.; Ye, Z.Y.; Wang, W.; Jiang, X.T.; et al. Recurrent TERT promoter mutations identified in a large-scale study of multiple tumour types are associated with increased TERT expression and telomerase activation. Eur. J. Cancer 2015, 51, 969-976. [CrossRef] [PubMed]

261. Koelsche, C.; Renner, M.; Hartmann, W.; Brandt, R.; Lehner, B.; Waldburger, N.; Alldinger, I.; Schmitt, T.; Egerer, G.; Penzel, R.; et al. TERT promoter hotspot mutations are recurrent in myxoid liposarcomas but rare in other soft tissue sarcoma entities. J. Exp. Clin. Cancer Res. 2014. [CrossRef] [PubMed]

262. Vail, E.; Zheng, X.; Zhou, M.; Yang, X.; Fallon, J.T.; Epstein, J.I.; Zhong, M. Telomerase reverse transcriptase promoter mutations in glandular lesions of the urinary bladder. Ann. Diagn. Pathol. 2015, 19, 301-305. [CrossRef] [PubMed] 
263. Nonoguchi, N.; Ohta, T.; Oh, J.E.; Kim, Y.H.; Kleihues, P.; Ohgaki, H. TERT promoter mutations in primary and secondary glioblastomas. Acta Neuropathol. 2013, 126, 931-937. [CrossRef] [PubMed]

264. Arita, H.; Narita, Y.; Fukushima, S.; Tateishi, K.; Matsushita, Y.; Yoshida, A.; Miyakita, Y.; Ohno, M.; Collins, V.P.; Kawahara, N.; et al. Upregulating mutations in the TERT promoter commonly occur in adult malignant gliomas and are strongly associated with total 1p19q loss. Acta Neuropathol. 2013, 126, 267-276. [CrossRef] [PubMed]

265. Mosrati, M.A.; Malmstrom, A.; Lysiak, M.; Krysztofiak, A.; Hallbeck, M.; Milos, P.; Hallbeck, A.L.; Bratthall, C.; Strandeus, M.; Stenmark-Askmalm, M.; et al. TERT promoter mutations and polymorphisms as prognostic factors in primary glioblastoma. Oncotarget 2015, 6, 16663-16673. [CrossRef] [PubMed]

266. Simon, M.; Hosen, I.; Gousias, K.; Rachakonda, S.; Heidenreich, B.; Gessi, M.; Schramm, J.; Hemminki, K.; Waha, A.; Kumar, R. TERT promoter mutations: A novel independent prognostic factor in primary glioblastomas. Neuro-Oncology 2015, 17, 45-52. [CrossRef] [PubMed]

267. Labussiere, M.; Boisselier, B.; Mokhtari, K.; Di Stefano, A.L.; Rahimian, A.; Rossetto, M.; Ciccarino, P.; Saulnier, O.; Paterra, R.; Marie, Y.; et al. Combined analysis of TERT, EGFR, and IDH status defines distinct prognostic glioblastoma classes. Neurology 2014, 83, 1200-1206. [CrossRef] [PubMed]

268. Heidenreich, B.; Rachakonda, P.S.; Hosen, I.; Volz, F.; Hemminki, K.; Weyerbrock, A.; Kumar, R. TERT promoter mutations and telomere length in adult malignant gliomas and recurrences. Oncotarget 2015, 6, 10617-10633. [CrossRef] [PubMed]

269. Liu, X.; Wu, G.; Shan, Y.; Hartmann, C.; von Deimling, A.; Xing, M. Highly prevalent TERT promoter mutations in bladder cancer and glioblastoma. Cell Cycle 2013, 12, 1637-1638. [CrossRef] [PubMed]

270. Vinagre, J.; Almeida, A.; Populo, H.; Batista, R.; Lyra, J.; Pinto, V.; Coelho, R.; Celestino, R.; Prazeres, H.; Lima, L.; et al. Frequency of TERT promoter mutations in human cancers. Nat. Commun. 2013. [CrossRef] [PubMed]

271. Fredriksson, N.J.; Ny, L.; Nilsson, J.A.; Larsson, E. Systematic analysis of noncoding somatic mutations and gene expression alterations across 14 tumor types. Nat. Genet. 2014, 46, 1258-1263. [CrossRef] [PubMed]

272. Batista, R.; Cruvinel-Carloni, A.; Vinagre, J.; Peixoto, J.; Catarino, T.A.; Campanella, N.C.; Menezes, W.; Becker, A.P.; de Almeida, G.C.; Matsushita, M.M.; et al. The prognostic impact of TERT promoter mutations in glioblastomas is modified by the rs2853669 single nucleotide polymorphism. Int. J. Cancer 2016, 139, 414-423. [CrossRef] [PubMed]

273. Nencha, U.; Rahimian, A.; Giry, M.; Sechi, A.; Mokhtari, K.; Polivka, M.; Schmitt, Y.; Di Stefano, A.L.; Alentorn, A.; Labussiere, M.; et al. TERT promoter mutations and rs2853669 polymorphism: Prognostic impact and interactions with common alterations in glioblastomas. J. Neurooncol. 2016, 126, 441-446. [CrossRef] [PubMed]

274. Spiegl-Kreinecker, S.; Lotsch, D.; Ghanim, B.; Pirker, C.; Mohr, T.; Laaber, M.; Weis, S.; Olschowski, A.; Webersinke, G.; Pichler, J.; et al. Prognostic quality of activating TERT promoter mutations in glioblastoma: Interaction with the rs2853669 polymorphism and patient age at diagnosis. Neuro-Oncology 2015, 17, 1231-1240. [CrossRef] [PubMed]

275. Brennan, C.W.; Verhaak, R.G.; McKenna, A.; Campos, B.; Noushmehr, H.; Salama, S.R.; Zheng, S.; Chakravarty, D.; Sanborn, J.Z.; Berman, S.H.; et al. The somatic genomic landscape of glioblastoma. Cell 2013, 155, 462-477. [CrossRef] [PubMed]

276. Killela, P.J.; Pirozzi, C.J.; Healy, P.; Reitman, Z.J.; Lipp, E.; Rasheed, B.A.; Yang, R.; Diplas, B.H.; Wang, Z.; Greer, P.K.; et al. Mutations in IDH1, IDH2, and in the TERT promoter define clinically distinct subgroups of adult malignant gliomas. Oncotarget 2014, 5, 1515-1525. [CrossRef] [PubMed]

277. Gao, K.; Li, G.; Qu, Y.; Wang, M.; Cui, B.; Ji, M.; Shi, B.; Hou, P. TERT promoter mutations and long telomere length predict poor survival and radiotherapy resistance in gliomas. Oncotarget 2016, 7, 8712-8725. [PubMed]

278. Labussiere, M.; Di Stefano, A.L.; Gleize, V.; Boisselier, B.; Giry, M.; Mangesius, S.; Bruno, A.; Paterra, R.; Marie, Y.; Rahimian, A.; et al. TERT promoter mutations in gliomas, genetic associations and clinico-pathological correlations. Br. J. Cancer 2014, 111, 2024-2032. [CrossRef] [PubMed]

279. Griewank, K.G.; Murali, R.; Puig-Butille, J.A.; Schilling, B.; Livingstone, E.; Potrony, M.; Carrera, C.; Schimming, T.; Moller, I.; Schwamborn, M.; et al. TERT promoter mutation status as an independent prognostic factor in cutaneous melanoma. J. Natl. Cancer Inst. 2014. [CrossRef] [PubMed] 
280. Rachakonda, P.S.; Hosen, I.; de Verdier, P.J.; Fallah, M.; Heidenreich, B.; Ryk, C.; Wiklund, N.P.; Steineck, G.; Schadendorf, D.; Hemminki, K.; et al. TERT promoter mutations in bladder cancer affect patient survival and disease recurrence through modification by a common polymorphism. Proc. Natl. Acad. Sci. USA 2013, 110, 17426-17431. [CrossRef] [PubMed]

281. Hurst, C.D.; Platt, F.M.; Knowles, M.A. Comprehensive mutation analysis of the TERT promoter in bladder cancer and detection of mutations in voided urine. Eur. Urol. 2014, 65, 367-369. [CrossRef] [PubMed]

282. Allory, Y.; Beukers, W.; Sagrera, A.; Flandez, M.; Marques, M.; Marquez, M.; van der Keur, K.A.; Dyrskjot, L.; Lurkin, I.; Vermeij, M.; et al. Telomerase reverse transcriptase promoter mutations in bladder cancer: High frequency across stages, detection in urine, and lack of association with outcome. Eur. Urol. 2014, 65, 360-366. [CrossRef] [PubMed]

283. Wang, K.; Liu, T.; Liu, C.; Meng, Y.; Yuan, X.; Liu, L.; Ge, N.; Liu, J.; Wang, C.; Ren, H.; et al. TERT promoter mutations and TERT mrna but not FGFR3 mutations are urinary biomarkers in han chinese patients with urothelial bladder cancer. Oncologist 2015, 20, 263-269. [CrossRef] [PubMed]

284. Yuan, X.; Liu, C.; Wang, K.; Liu, L.; Liu, T.; Ge, N.; Kong, F.; Yang, L.; Bjorkholm, M.; Fan, Y.; et al. The genetic difference between western and chinese urothelial cell carcinomas: Infrequent FGFR3 mutation in han chinese patients. Oncotarget 2016. [CrossRef] [PubMed]

285. Wu, S.; Huang, P.; Li, C.; Huang, Y.; Li, X.; Wang, Y.; Chen, C.; Lv, Z.; Tang, A.; Sun, X.; et al. Telomerase reverse transcriptase gene promoter mutations help discern the origin of urogenital tumors: A genomic and molecular study. Eur. Urol. 2014, 65, 274-277. [CrossRef] [PubMed]

286. Kurtis, B.; Zhuge, J.; Ojaimi, C.; Ye, F.; Cai, D.; Zhang, D.; Fallon, J.T.; Zhong, M. Recurrent TERT promoter mutations in urothelial carcinoma and potential clinical applications. Ann. Diagn. Pathol. 2016, 21, 7-11. [CrossRef] [PubMed]

287. Cheng, L.; Davidson, D.D.; Wang, M.; Lopez-Beltran, A.; Montironi, R.; Wang, L.; Tan, P.H.; MacLennan, G.T.; Williamson, S.R.; Zhang, S. Telomerase reverse transcriptase (TERT) promoter mutation analysis of benign, malignant and reactive urothelial lesions reveals a subpopulation of inverted papilloma with immortalizing genetic change. Histopathology 2015, 69, 107-113. [CrossRef] [PubMed]

288. Borah, S.; Xi, L.; Zaug, A.J.; Powell, N.M.; Dancik, G.M.; Cohen, S.B.; Costello, J.C.; Theodorescu, D.; Cech, T.R. TERT promoter mutations and telomerase reactivation in urothelial cancer. Science 2015, 347, 1006-1010. [CrossRef] [PubMed]

289. Zhong, M.; Tian, W.; Zhuge, J.; Zheng, X.; Huang, T.; Cai, D.; Zhang, D.; Yang, X.J.; Argani, P.; Fallon, J.T.; et al. Distinguishing nested variants of urothelial carcinoma from benign mimickers by TERT promoter mutation. Am. J. Surg. Pathol. 2015, 39, 127-131. [CrossRef] [PubMed]

290. Scott, G.A.; Laughlin, T.S.; Rothberg, P.G. Mutations of the TERT promoter are common in basal cell carcinoma and squamous cell carcinoma. Mod. Pathol. 2014, 27, 516-523. [CrossRef] [PubMed]

291. Griewank, K.G.; Murali, R.; Schilling, B.; Schimming, T.; Moller, I.; Moll, I.; Schwamborn, M.; Sucker, A.; Zimmer, L.; Schadendorf, D.; et al. TERT promoter mutations are frequent in cutaneous basal cell carcinoma and squamous cell carcinoma. PLoS ONE 2013, 8, e80354. [CrossRef] [PubMed]

292. Populo, H.; Boaventura, P.; Vinagre, J.; Batista, R.; Mendes, A.; Caldas, R.; Pardal, J.; Azevedo, F.; Honavar, M.; Guimaraes, I.; et al. TERT promoter mutations in skin cancer: The effects of sun exposure and x-irradiation. J. Investig. Dermatol. 2014, 134, 2251-2257. [CrossRef] [PubMed]

293. Lin, S.Y.; Liao, S.L.; Hong, J.B.; Chu, C.Y.; Sheen, Y.S.; Jhuang, J.Y.; Tsai, J.H.; Liau, J.Y. TERT promoter mutations in periocular carcinomas: Implications of ultraviolet light in pathogenesis. Br. J. Ophthalmol. 2016, 100, 274-277. [CrossRef] [PubMed]

294. Cheng, K.A.; Kurtis, B.; Babayeva, S.; Zhuge, J.; Tantchou, I.; Cai, D.; Lafaro, R.J.; Fallon, J.T.; Zhong, M. Heterogeneity of TERT promoter mutations status in squamous cell carcinomas of different anatomical sites. Ann. Diagn. Pathol. 2015, 19, 146-148. [CrossRef] [PubMed]

295. Liu, J.; Zhao, Z.; Sun, M.; Chen, K.; Yuan, W.; Jiang, G. The sensitive detection of telomerase reverse transcriptase promoter mutation by amplification refractory mutation system-PCR. Genet. Test. Mol. Biomark. 2016, 20, 90-93. [CrossRef] [PubMed]

296. Liu, X.; Bishop, J.; Shan, Y.; Pai, S.; Liu, D.; Murugan, A.K.; Sun, H.; El-Naggar, A.K.; Xing, M. Highly prevalent TERT promoter mutations in aggressive thyroid cancers. Endocr. Relat. Cancer 2013, 20, 603-610. [CrossRef] [PubMed] 
297. Landa, I.; Ganly, I.; Chan, T.A.; Mitsutake, N.; Matsuse, M.; Ibrahimpasic, T.; Ghossein, R.A.; Fagin, J.A. Frequent somatic TERT promoter mutations in thyroid cancer: Higher prevalence in advanced forms of the disease. J. Clin. Endocrinol. Metab. 2013, 98, E1562-E1566. [CrossRef] [PubMed]

298. Shi, X.; Liu, R.; Qu, S.; Zhu, G.; Bishop, J.; Liu, X.; Sun, H.; Shan, Z.; Wang, E.; Luo, Y.; et al. Association of TERT promoter mutation 1,295,228 $\mathrm{c}>\mathrm{t}$ with braf v600e mutation, older patient age, and distant metastasis in anaplastic thyroid cancer. J. Clin. Endocrinol. Metab. 2015, 100, E632-E637. [CrossRef] [PubMed]

299. Melo, M.; da Rocha, A.G.; Vinagre, J.; Batista, R.; Peixoto, J.; Tavares, C.; Celestino, R.; Almeida, A.; Salgado, C.; Eloy, C.; et al. TERT promoter mutations are a major indicator of poor outcome in differentiated thyroid carcinomas. J. Clin. Endocrinol. Metab. 2014, 99, E754-E765. [CrossRef] [PubMed]

300. Liu, T.; Wang, N.; Cao, J.; Sofiadis, A.; Dinets, A.; Zedenius, J.; Larsson, C.; Xu, D. The age- and shorter telomere-dependent TERT promoter mutation in follicular thyroid cell-derived carcinomas. Oncogene 2014, 33, 4978-4984. [CrossRef] [PubMed]

301. Landa, I.; Ibrahimpasic, T.; Boucai, L.; Sinha, R.; Knauf, J.A.; Shah, R.H.; Dogan, S.; Ricarte-Filho, J.C.; Krishnamoorthy, G.P.; Xu, B.; et al. Genomic and transcriptomic hallmarks of poorly differentiated and anaplastic thyroid cancers. J. Clin. Investig. 2016, 126, 1052-1066. [CrossRef] [PubMed]

302. Wang, K.; Liu, T.; Ge, N.; Liu, L.; Yuan, X.; Liu, J.; Kong, F.; Wang, C.; Ren, H.; Yan, K.; et al. TERT promoter mutations are associated with distant metastases in upper tract urothelial carcinomas and serve as urinary biomarkers detected by a sensitive castpcr. Oncotarget 2014, 5, 12428-12439. [CrossRef] [PubMed]

303. Nault, J.C.; Mallet, M.; Pilati, C.; Calderaro, J.; Bioulac-Sage, P.; Laurent, C.; Laurent, A.; Cherqui, D.; Balabaud, C.; Zucman-Rossi, J. High frequency of telomerase reverse-transcriptase promoter somatic mutations in hepatocellular carcinoma and preneoplastic lesions. Nat. Commun. 2013. [CrossRef]

304. Cevik, D.; Yildiz, G.; Ozturk, M. Common telomerase reverse transcriptase promoter mutations in hepatocellular carcinomas from different geographical locations. World J. Gastroenterol. 2015, 21, 311-317. [CrossRef] [PubMed]

305. Chen, Y.L.; Jeng, Y.M.; Chang, C.N.; Lee, H.J.; Hsu, H.C.; Lai, P.L.; Yuan, R.H. TERT promoter mutation in resectable hepatocellular carcinomas: A strong association with hepatitis c infection and absence of hepatitis b infection. Int. J. Surg. 2014, 12, 659-665. [CrossRef] [PubMed]

306. Yang, X.; Guo, X.; Chen, Y.; Chen, G.; Ma, Y.; Huang, K.; Zhang, Y.; Zhao, Q.; Winkler, C.A.; An, P.; et al. Telomerase reverse transcriptase promoter mutations in hepatitis B virus-associated hepatocellular carcinoma. Oncotarget 2016. [CrossRef] [PubMed]

307. Totoki, Y.; Tatsuno, K.; Covington, K.R.; Ueda, H.; Creighton, C.J.; Kato, M.; Tsuji, S.; Donehower, L.A.; Slagle, B.L.; Nakamura, H.; et al. Trans-ancestry mutational landscape of hepatocellular carcinoma genomes. Nat. Genet. 2014, 46, 1267-1273. [CrossRef] [PubMed]

308. de Unamuno Bustos, B.; Murria Estal, R.; Perez Simo, G.; Oliver Martinez, V.; Llavador Ros, M.; Palanca Suela, S.; Botella Estrada, R. Lack of TERT promoter mutations in melanomas with extensive regression. J. Am. Acad. Dermatol. 2016, 74, 570-572. [CrossRef] [PubMed]

309. Egberts, F.; Kruger, S.; Behrens, H.M.; Bergner, I.; Papaspyrou, G.; Werner, J.A.; Alkatout, I.; Haag, J.; Hauschild, A.; Rocken, C. Melanomas of unknown primary frequently harbor TERT-promoter mutations. Melanoma Res. 2014, 24, 131-136. [CrossRef] [PubMed]

310. Chan, A.K.; Yao, Y.; Zhang, Z.; Chung, N.Y.; Liu, J.S.; Li, K.K.; Shi, Z.; Chan, D.T.; Poon, W.S.; Zhou, L.; et al. TERT promoter mutations contribute to subset prognostication of lower-grade gliomas. Mod. Pathol. 2015, 28, 177-186. [CrossRef] [PubMed]

311. Koopmans, A.E.; Ober, K.; Dubbink, H.J.; Paridaens, D.; Naus, N.C.; Belunek, S.; Krist, B.; Post, E.; Zwarthoff, E.C.; de Klein, A.; et al. Prevalence and implications of TERT promoter mutation in uveal and conjunctival melanoma and in benign and premalignant conjunctival melanocytic lesions. Investig. Ophthalmol. Vis. Sci. 2014, 55, 6024-6030. [CrossRef] [PubMed]

312. Griewank, K.G.; Murali, R.; Schilling, B.; Scholz, S.; Sucker, A.; Song, M.; Susskind, D.; Grabellus, F.; Zimmer, L.; Hillen, U.; et al. TERT promoter mutations in ocular melanoma distinguish between conjunctival and uveal tumours. Br. J. Cancer 2013, 109, 497-501. [CrossRef] [PubMed]

313. Heidenreich, B.; Nagore, E.; Rachakonda, P.S.; Garcia-Casado, Z.; Requena, C.; Traves, V.; Becker, J.; Soufir, N.; Hemminki, K.; Kumar, R. Telomerase reverse transcriptase promoter mutations in primary cutaneous melanoma. Nat. Commun. 2014. [CrossRef] [PubMed] 
314. Macerola, E.; Loggini, B.; Giannini, R.; Garavello, G.; Giordano, M.; Proietti, A.; Niccoli, C.; Basolo, F.; Fontanini, G. Coexistence of TERT promoter and braf mutations in cutaneous melanoma is associated with more clinicopathological features of aggressiveness. Virchows Arch. 2015, 467, 177-184. [CrossRef] [PubMed]

315. Qasem, E.; Murugan, A.K.; Al-Hindi, H.; Xing, M.; Almohanna, M.; Alswailem, M.; Alzahrani, A.S. TERT promoter mutations in thyroid cancer: A report from a middle eastern population. Endocr. Relat. Cancer 2015, 22, 901-908. [CrossRef] [PubMed]

316. Remke, M.; Ramaswamy, V.; Peacock, J.; Shih, D.J.; Koelsche, C.; Northcott, P.A.; Hill, N.; Cavalli, F.M.; Kool, M.; Wang, X.; et al. TERT promoter mutations are highly recurrent in shh subgroup medulloblastoma. Acta Neuropathol. 2013, 126, 917-929. [CrossRef] [PubMed]

317. Lindsey, J.C.; Schwalbe, E.C.; Potluri, S.; Bailey, S.; Williamson, D.; Clifford, S.C. TERT promoter mutation and aberrant hypermethylation are associated with elevated expression in medulloblastoma and characterise the majority of non-infant shh subgroup tumours. Acta Neuropathol. 2014, 127, 307-309. [CrossRef] [PubMed]

318. Ohta, T.; Kim, Y.H.; Oh, J.E.; Satomi, K.; Nonoguchi, N.; Keyvani, K.; Pierscianek, D.; Sure, U.; Mittelbronn, M.; Paulus, W.; et al. Alterations of the RRAS and ERCC1 genes at 19q13 in gemistocytic astrocytomas. J. Neuropathol. Exp. Neurol. 2014, 73, 908-915. [CrossRef] [PubMed]

319. Bruno, A.; Alentorn, A.; Daniau, M.; Labussiere, M.; Rahimian, A.; Tabouret, E.; Polivka, M.; Jouvet, A.; Adam, C.; Figarella-Branger, D.; et al. TERT promoter mutations in primary central nervous system lymphoma are associated with spatial distribution in the splenium. Acta Neuropathol. 2015, 130, 439-440. [CrossRef] [PubMed]

320. Muzza, M.; Colombo, C.; Rossi, S.; Tosi, D.; Cirello, V.; Perrino, M.; De Leo, S.; Magnani, E.; Pignatti, E.; Vigo, B.; et al. Telomerase in differentiated thyroid cancer: Promoter mutations, expression and localization. Mol. Cell. Endocrinol. 2015, 399, 288-295. [CrossRef] [PubMed]

321. Wang, N.; Liu, T.; Sofiadis, A.; Juhlin, C.C.; Zedenius, J.; Hoog, A.; Larsson, C.; Xu, D. TERT promoter mutation as an early genetic event activating telomerase in follicular thyroid adenoma (FTA) and atypical FTA. Cancer 2014, 120, 2965-2979. [CrossRef] [PubMed]

322. Song, Y.S.; Lim, J.A.; Choi, H.; Won, J.K.; Moon, J.H.; Cho, S.W.; Lee, K.E.; Park, Y.J.; Yi, K.H.; Park do, J.; et al. Prognostic effects of TERT promoter mutations are enhanced by coexistence with BRAF or RAS mutations and strengthen the risk prediction by the ATA or TNM staging system in differentiated thyroid cancer patients. Cancer 2016, 122, 1370-1379. [CrossRef] [PubMed]

323. Bae, J.S.; Kim, Y.; Jeon, S.; Kim, S.H.; Kim, T.J.; Lee, S.; Kim, M.H.; Lim, D.J.; Lee, Y.S.; Jung, C.K. Clinical utility of TERT promoter mutations and $A L K$ rearrangement in thyroid cancer patients with a high prevalence of the BRAF V600E mutation. Diagn. Pathol. 2016. [CrossRef] [PubMed]

324. Huang, H.N.; Chiang, Y.C.; Cheng, W.F.; Chen, C.A.; Lin, M.C.; Kuo, K.T. Molecular alterations in endometrial and ovarian clear cell carcinomas: Clinical impacts of telomerase reverse transcriptase promoter mutation. Mod. Pathol. 2015, 28, 303-311. [CrossRef] [PubMed]

325. Wu, R.C.; Ayhan, A.; Maeda, D.; Kim, K.R.; Clarke, B.A.; Shaw, P.; Chui, M.H.; Rosen, B.; Shih Ie, M.; Wang, T.L. Frequent somatic mutations of the telomerase reverse transcriptase promoter in ovarian clear cell carcinoma but not in other major types of gynaecological malignancy. J. Pathol. 2014, 232, 473-481. [CrossRef] [PubMed]

326. Chindris, A.M.; Casler, J.D.; Bernet, V.J.; Rivera, M.; Thomas, C.; Kachergus, J.M.; Necela, B.M.; Hay, I.D.; Westphal, S.A.; Grant, C.S.; et al. Clinical and molecular features of hurthle cell carcinoma of the thyroid. J. Clin. Endocrinol. Metab. 2015, 100, 55-62. [CrossRef] [PubMed]

327. Tallet, A.; Nault, J.C.; Renier, A.; Hysi, I.; Galateau-Salle, F.; Cazes, A.; Copin, M.C.; Hofman, P.; Andujar, P.; Le Pimpec-Barthes, F; et al. Overexpression and promoter mutation of the TERT gene in malignant pleural mesothelioma. Oncogene 2014, 33, 3748-3752. [CrossRef] [PubMed]

328. Akaike, K.; Kurisaki-Arakawa, A.; Hara, K.; Suehara, Y.; Takagi, T.; Mitani, K.; Kaneko, K.; Yao, T.; Saito, T. Distinct clinicopathological features of NAB2-STAT6 fusion gene variants in solitary fibrous tumor with emphasis on the acquisition of highly malignant potential. Hum. Pathol. 2015, 46, 347-356. [CrossRef] [PubMed]

329. Liau, J.Y.; Tsai, J.H.; Jeng, Y.M.; Chu, C.Y.; Kuo, K.T.; Liang, C.W. TERT promoter mutation is uncommon in acral lentiginous melanoma. J. Cutan. Pathol. 2014, 41, 504-508. [CrossRef] [PubMed] 
330. George, J.R.; Henderson, Y.C.; Williams, M.D.; Roberts, D.B.; Hei, H.; Lai, S.Y.; Clayman, G.L. Association of TERT promoter mutation, but not BRAF mutation, with increased mortality in PTC. J. Clin. Endocrinol. Metab. 2015, 100, E1550-E1559. [CrossRef] [PubMed]

331. Xing, M.; Liu, R.; Liu, X.; Murugan, A.K.; Zhu, G.; Zeiger, M.A.; Pai, S.; Bishop, J. BRAF V600E and TERT promoter mutations cooperatively identify the most aggressive papillary thyroid cancer with highest recurrence. J. Clin. Oncol. 2014, 32, 2718-2726. [CrossRef] [PubMed]

332. Liu, R.; Xing, M. Diagnostic and prognostic TERT promoter mutations in thyroid fine-needle aspiration biopsy. Endocr. Relat. Cancer 2014, 21, 825-830. [CrossRef] [PubMed]

333. Liu, X.; Qu, S.; Liu, R.; Sheng, C.; Shi, X.; Zhu, G.; Murugan, A.K.; Guan, H.; Yu, H.; Wang, Y.; et al. TERT promoter mutations and their association with BRAF V600E mutation and aggressive clinicopathological characteristics of thyroid cancer. J. Clin. Endocrinol. Metab. 2014, 99, E1130-E1136. [CrossRef] [PubMed]

334. Dettmer, M.S.; Schmitt, A.; Steinert, H.; Capper, D.; Moch, H.; Komminoth, P.; Perren, A. Tall cell papillary thyroid carcinoma: New diagnostic criteria and mutations in braf and TERT. Endocr. Relat. Cancer 2015, 22, 419-429. [CrossRef] [PubMed]

335. Jin, L.; Chen, E.; Dong, S.; Cai, Y.; Zhang, X.; Zhou, Y.; Zeng, R.; Yang, F.; Pan, C.; Liu, Y.; et al. BRAF and TERT promoter mutations in the aggressiveness of papillary thyroid carcinoma: A study of 653 patients. Oncotarget 2016, 7, 18346-18355. [CrossRef] [PubMed]

336. Myung, J.K.; Kwak, B.K.; Lim, J.A.; Lee, M.C.; Kim, M.J. TERT Promoter mutations and tumor persistence/recurrence in papillary thyroid cancer. Cancer Res. Treat. 2016, 48, 942-947. [CrossRef] [PubMed]

337. Jeon, M.J.; Kim, W.G.; Sim, S.; Lim, S.; Kwon, H.; Kim, T.Y.; Shong, Y.K.; Kim, W.B. Low prevalence of somatic TERT promoter mutations in classic papillary thyroid carcinoma. Endocrinol. Metab. 2016, 31, 100-104. [CrossRef] [PubMed]

338. Bullock, M.; Ren, Y.; O’Neill, C.; Gill, A.; Aniss, A.; Sywak, M.; Sidhu, S.; Delbridge, L.; Learoyd, D.; de Vathaire, F.; et al. TERT promoter mutations are a major indicator of recurrence and death due to papillary thyroid carcinomas. Clin. Endocrinol. 2016, 85, 283-190. [CrossRef] [PubMed]

339. Qu, Y.; Shi, L.; Wang, D.; Zhang, B.; Yang, Q.; Ji, M.; Shi, B.; Hou, P. Low frequency of TERT promoter mutations in a large cohort of gallbladder and gastric cancers. Int. J. Cancer 2014, 134, 2993-2994. [CrossRef] [PubMed]

340. Papathomas, T.G.; Oudijk, L.; Zwarthoff, E.C.; Post, E.; Duijkers, F.A.; van Noesel, M.M.; Hofland, L.J.; Pollard, P.J.; Maher, E.R.; Restuccia, D.F.; et al. Telomerase reverse transcriptase promoter mutations in tumors originating from the adrenal gland and extra-adrenal paraganglia. Endocr. Relat. Cancer 2014, 21, 653-661. [CrossRef] [PubMed]

341. Liu, T.; Brown, T.C.; Juhlin, C.C.; Andreasson, A.; Wang, N.; Backdahl, M.; Healy, J.M.; Prasad, M.L.; Korah, R.; Carling, T.; et al. The activating TERT promoter mutation C228T is recurrent in subsets of adrenal tumors. Endocr. Relat. Cancer 2014, 21, 427-434. [CrossRef] [PubMed]

342. Wang, K.; Liu, T.; Liu, L.; Liu, J.; Liu, C.; Wang, C.; Ge, N.; Ren, H.; Yan, K.; Hu, S.; et al. TERT promoter mutations in renal cell carcinomas and upper tract urothelial carcinomas. Oncotarget 2014, 5, 1829-1836. [CrossRef] [PubMed]

343. Jangard, M.; Zebary, A.; Ragnarsson-Olding, B.; Hansson, J. TERT promoter mutations in sinonasal malignant melanoma: A study of 49 cases. Melanoma Res. 2015, 25, 185-188. [CrossRef] [PubMed]

344. Lee, S.; Barnhill, R.L.; Dummer, R.; Dalton, J.; Wu, J.; Pappo, A.; Bahrami, A. TERT promoter mutations are predictive of aggressive clinical behavior in patients with spitzoid melanocytic neoplasms. Sci. Rep. 2015. [CrossRef] [PubMed]

345. Goutagny, S.; Nault, J.C.; Mallet, M.; Henin, D.; Rossi, J.Z.; Kalamarides, M. High incidence of activating TERT promoter mutations in meningiomas undergoing malignant progression. Brain Pathol. 2014, 24, 184-189. [CrossRef] [PubMed]

346. Sahm, F.; Schrimpf, D.; Olar, A.; Koelsche, C.; Reuss, D.; Bissel, J.; Kratz, A.; Capper, D.; Schefzyk, S.; Hielscher, T.; et al. TERT promoter mutations and risk of recurrence in meningioma. J. Natl. Cancer Inst. 2016. [CrossRef]

347. Carcano, F.M.; Vidal, D.O.; van Helvoort Lengert, A.; Neto, C.S.; Queiroz, L.; Marques, H.; Baltazar, F.; da Silva Martinelli, C.M.; Soares, P.; da Silva, E.C.; et al. Hotspot TERT promoter mutations are rare events in testicular germ cell tumors. Tumour Biol. 2016, 37, 4901-4907. [CrossRef] 
348. Campanella, N.C.; Celestino, R.; Pestana, A.; Scapulatempo-Neto, C.; de Oliveira, A.T.; Brito, M.J.; Gouveia, A.; Lopes, J.M.; Guimaraes, D.P.; Soares, P.; et al. Low frequency of TERT promoter mutations in gastrointestinal stromal tumors (GISTs). Eur. J. Hum. Genet. 2015, 23, 877-879. [CrossRef] [PubMed]

349. Akaike, K.; Toda-Ishii, M.; Suehara, Y.; Mukaihara, K.; Kubota, D.; Mitani, K.; Takagi, T.; Kaneko, K.; Yao, T.; Saito, T. TERT promoter mutations are a rare event in gastrointestinal stromal tumors. Springerplus 2015. [CrossRef] [PubMed]

350. Zhao, Y.; Gao, Y.; Chen, Z.; Hu, X.; Zhou, F.; He, J. Low frequency of TERT promoter somatic mutation in 313 sporadic esophageal squamous cell carcinomas. Int. J. Cancer 2014, 134, 493-494. [CrossRef]

351. Dono, M.; Angelini, G.; Cecconi, M.; Amaro, A.; Esposito, A.I.; Mirisola, V.; Maric, I.; Lanza, F.; Nasciuti, F.; Viaggi, S.; et al. Mutation frequencies of GNAQ, GNA11, BAP1, SF3B1, EIF1AX and TERT in uveal melanoma: Detection of an activating mutation in the TERT gene promoter in a single case of uveal melanoma. Br. J. Cancer 2014, 110, 1058-1065. [CrossRef] [PubMed]

352. Hosen, I.; Rachakonda, P.S.; Heidenreich, B.; de Verdier, P.J.; Ryk, C.; Steineck, G.; Hemminki, K.; Kumar, R. Mutations in TERT promoter and FGFR3 and telomere length in bladder cancer. Int. J. Cancer 2015, 137, 1621-1629. [CrossRef] [PubMed]

353. Qu, Y.; Dang, S.; Wu, K.; Shao, Y.; Yang, Q.; Ji, M.; Shi, B.; Hou, P. TERT promoter mutations predict worse survival in laryngeal cancer patients. Int. J. Cancer 2014, 135, 1008-1010. [CrossRef] [PubMed]

354. Hanahan, D.; Weinberg, R.A. Hallmarks of cancer: The next generation. Cell 2011, 144, 646-674. [CrossRef] [PubMed]

355. Ruden, M.; Puri, N. Novel anticancer therapeutics targeting telomerase. Cancer Treat. Rev. 2013, 39, 444-456. [CrossRef] [PubMed]

(C) 2016 by the authors; licensee MDPI, Basel, Switzerland. This article is an open access article distributed under the terms and conditions of the Creative Commons Attribution (CC-BY) license (http://creativecommons.org/licenses/by/4.0/). 